\title{
The Eighteenth Brumaire of Louis Bonaparte
}

Written: December 1851-March 1852;

Source: Chapters $1 \& 7$ are translated by Saul K. Padover from the German edition of 1869; Chapters 2 through 6 are based on the third edition, prepared by Engels (1885), as translated and published by Progress Publishers, Moscow, 1937;

First Published: First issue of Die Revolution, 1852, New York;

Transcription/Markup: Zodiac and Brian Baggins for Marx/Engels Internet Archive 1995, 1999;

Proofed: and corrected by Alek Blain, 2006, Mark Harris, 2010. 


\section{Preface to the Second Edition (1869)}

My friend Joseph Weydemeyer, whose death was so untimely, intended to publish a political weekly in New York starting from January 1, 1852. He invited me to provide this weekly with a history of the coup d'etat. Down to the middle of February, I accordingly wrote him weekly articles under the title The Eighteenth Brumaire of Louis Bonaparte. Meanwhile, Weydemeyer's original plan had fallen through. Instead, in the spring of 1852 he began to publish a monthly, Die Revolution, whose first number consists of my Eighteenth Brumaire. A few hundred copies of this found their way into Germany at that time, without, however, getting into the actual book market. A German bookseller of extremely radical pretensions to whom I offered the sale of my book was most virtuously horrified at a "presumption" so "contrary to the times."

From the above facts it will be seen that the present work took shape under the immediate pressure of events and its historical material does not extend beyond the month of February, 1852. Its republication now is due in part to the demand of the book trade, in part to the urgent requests of my friends in Germany.

Of the writings dealing with the same subject at approximately the same time as mine, only two deserve notice: Victor Hugo's Napoleon le Petit and Proudhon's Coup d'Etat. Victor Hugo confines himself to bitter and witty invective against the responsible producer of the coup d'etat. The event itself appears in his work like a bolt from the blue. He sees in it only the violent act of a single individual. He does not notice that he makes this individual great instead of little by ascribing to him a personal power of initiative unparalleled in world history. Proudhon, for his part, seeks to represent the coup d'etat as the result of an antecedent historical development. Inadvertently, however, his historical construction of the coup d'etat becomes a historical apologia for its hero. Thus he falls into the error of our so-called objective historians. I, on the contrary, demonstrate how the class struggle in France created circumstances and relationships that made it possible for a grotesque mediocrity to play a hero's part.

A revision of the present work would have robbed it of its particular coloring. Accordingly, I have confined myself to mere correction of printer's errors and to striking out allusions now no longer intelligible.

The concluding words of my work: "But when the imperial mantle finally falls on the shoulders of Louis Bonaparte, the bronze statue of Napoleon will come crashing down from the top of the Vendome Column," have already been fulfilled. Colonel Charras opened the attack on the Napoleon cult in his work on the campaign of 1815. Subsequently, and especially in the past few years, French literature has made an end of the Napoleon legend with the weapons of historical research, criticism, satire, and wit. Outside France, this violent breach with the traditional popular belief, this tremendous mental revolution, has been little noticed and still less understood.

Lastly, I hope that my work will contribute toward eliminating the school-taught phrase now current, particularly in Germany, of so-called Caesarism. In this superficial historical analogy the main point is forgotten, namely, that in ancient Rome the class struggle took place only within a privileged minority, between the free rich and the free poor, while the great productive mass of the population, the slaves, formed the purely passive pedestal for these combatants. People forget Sismondi's significant saying: The Roman proletariat lived at the expense of society, while modern society lives at the expense of the proletariat. With so complete a difference between the material, economic conditions of the ancient and the modern class struggles, the political figures produced by them can likewise have no more in common with one another than the Archbishop of Canterbury has with the High Priest Samuel.

Karl Marx,

London, June 25, 1869 


\section{Preface to the Third German Edition (Engels,}

\section{5)}

The fact that a new edition of The Eighteenth Brumaire ${ }^{l}$ has become necessary, thirty-three years after its first appearance, proves that even today this little book has lost none of its value.

It was in truth a work of genius. Immediately after the event that struck the whole political world like a thunderbolt from the blue, that was condemned by some with loud cries of moral indignation and accepted by others as salvation from the revolution and as punishment for its errors, but was only wondered at by all and understood by none-immediately after this event Marx came out with a concise, epigrammatic exposition that laid bare the whole course of French history since the February days in its inner interconnection, reduced the miracle of December $2^{2}$ to a natural, necessary result of this interconnection and in so doing did not even need to treat the hero of the coup d'état otherwise than with the contempt he so well deserved. And the picture was drawn with such a master hand that every fresh disclosure since made has only provided fresh proofs of how faithfully it reflected reality. This eminent understanding of the living history of the day, this clear-sighted appreciation of events at the moment of happening, is indeed without parallel.

But for this, Marx's thorough knowledge of French history was needed. France is the land where, more than anywhere else, the historical class struggles were each time fought out to a decision, and where, consequently, the changing political forms within which they move and in which their results are summarised have been stamped in the sharpest outlines. The centre of feudalism in the Middle Ages, the model country of unified monarchy, resting on estates, since the Renaissance, ${ }^{3}$ France demolished feudalism in the Great Revolution and established the unalloyed rule of the bourgeoisie in a classical purity unequalled by any other European land. And the struggle of the upward-striving proletariat against the ruling bourgeoisie appeared here in an acute form unknown elsewhere. This was the reason why Marx not only studied the past history of France with particular predilection, but also followed her current history in every detail, stored up the material for future use and, consequently, events never took him by surprise.

In addition, however, there was still another circumstance. It was precisely Marx who had first discovered the great law of motion of history, the law according to which all historical struggles, whether they proceed in the political, religious, philosophical or some other ideological domain, are in fact only the more or less clear expression of struggles of social classes, and that the existence and thereby the collisions, too, between these classes are in turn conditioned by the degree of development of their economic position, by the mode of their production and of their exchange determined by it. This law, which has the same significance for history as the law of the transformation of energy has for natural science - this law gave him here, too, the key to an understanding of the history of the Second French Republic. ${ }^{4}$ He put his law to the test on these historical events, and even after thirty-three years we must still say that it has stood the test brilliantly. 
${ }^{1}$ This work, written on the basis of a concrete analysis of the revolutionary events in France from 1848 to 1851, is one of the most important Marxist writings. In it Marx gives a further elaboration of all the basic tenets of historical materialism-the theory of the class struggle and proletarian revolution, the state and the dictatorship of the proletariat. Of extremely great importance is the conclusion which Marx arrived at on the question of the attitude of the proletariat to the bourgeois state. He says, "All revolutions perfected this machine instead of smashing it.". Lenin described it as one of the most important propositions in the Marxist teaching on the state.

In The Eighteenth Brumaire of Louis Bonaparte Marx continued his analysis of the question of the peasantry, as a potential ally of the working class in the imminent revolution, outlined the role of the political parties in the life of society and exposed for what they were the essential features of Bonapartism.

${ }^{2}$ On December 2, 1851 a counter-revolutionary coup d'état in France was carried out by Louis Bonaparte and his adherents.

${ }^{3}$ Renaissance-a period in the cultural and ideological development of a number of countries in Western and Central Europe called forth by the emergence of capitalist relations, which covers the second half of the fifteenth and the sixteenth century. This period is usually associated with a rapid development in the arts and sciences and the revival of interest in the culture of classical Greece and Rome (hence the name of the period). For Engels's description of the Renaissance see his "Introduction to Dialectics of Nature."

${ }^{4}$ The Second Republic existed in France from 1848 to 1852. For Marx's description of this period see The Class Struggles in France, 1848 to 1850 and The Eighteenth Brumaire of Louis Bonaparte. 


\section{I}

Hegel remarks somewhere ${ }^{1}$ that all great world-historic facts and personages appear, so to speak, twice. He forgot to add: the first time as tragedy, the second time as farce. Caussidière for Danton, Louis Blanc for Robespierre, the Montagne of 1848 to $1851^{2}$ for the Montagne of 1793 to 1795 , the nephew for the uncle. And the same caricature occurs in the circumstances of the second edition of the Eighteenth Brumaire.

Men make their own history, but they do not make it as they please; they do not make it under self-selected circumstances, but under circumstances existing already, given and transmitted from the past. The tradition of all dead generations weighs like a nightmare on the brains of the living. And just as they seem to be occupied with revolutionizing themselves and things, creating something that did not exist before, precisely in such epochs of revolutionary crisis they anxiously conjure up the spirits of the past to their service, borrowing from them names, battle slogans, and costumes in order to present this new scene in world history in time-honored disguise and borrowed language. Thus Luther put on the mask of the Apostle Paul, the Revolution of 1789-1814 draped itself alternately in the guise of the Roman Republic and the Roman Empire, and the Revolution of 1848 knew nothing better to do than to parody, now 1789, now the revolutionary tradition of 1793-95. In like manner, the beginner who has learned a new language always translates it back into his mother tongue, but he assimilates the spirit of the new language and expresses himself freely in it only when he moves in it without recalling the old and when he forgets his native tongue.

When we think about this conjuring up of the dead of world history, a salient difference reveals itself. Camille Desmoulins, Danton, Robespierre, St. Just, Napoleon, the heroes as well as the parties and the masses of the old French Revolution, performed the task of their time - that of unchaining and establishing modern bourgeois society - in Roman costumes and with Roman phrases. The first one destroyed the feudal foundation and cut off the feudal heads that had grown on it. The other created inside France the only conditions under which free competition could be developed, parceled-out land properly used, and the unfettered productive power of the nation employed; and beyond the French borders it swept away feudal institutions everywhere, to provide, as far as necessary, bourgeois society in France with an appropriate up-to-date environment on the European continent. Once the new social formation was established, the antediluvian colossi disappeared and with them also the resurrected Romanism - the Brutuses, the Gracchi, the publicolas, the tribunes, the senators, and Caesar himself. Bourgeois society in its sober reality bred its own true interpreters and spokesmen in the Says, Cousins, Royer-Collards, Benjamin Constants, and Guizots; its real military leaders sat behind the office desk and the hogheaded Louis XVIII was its political chief. Entirely absorbed in the production of wealth and in peaceful competitive struggle, it no longer remembered that the ghosts of the Roman period had watched over its cradle.

But unheroic though bourgeois society is, it nevertheless needed heroism, sacrifice, terror, civil war, and national wars to bring it into being. And in the austere classical traditions of the Roman Republic the bourgeois gladiators found the ideals and the art forms, the self-deceptions, that they needed to conceal from themselves the bourgeois-limited content of their struggles and to keep their passion on the high plane of great historic tragedy. Similarly, at another stage of development a century earlier, Cromwell and the English people had borrowed from the Old Testament the speech, emotions, and illusions for their bourgeois revolution. When the real goal had been achieved and the bourgeois transformation of English society had been accomplished, Locke supplanted Habakkuk. 
Thus the awakening of the dead in those revolutions served the purpose of glorifying the new struggles, not of parodying the old; of magnifying the given task in the imagination, not recoiling from its solution in reality; of finding once more the spirit of revolution, not making its ghost walk again.

From 1848 to 1851, only the ghost of the old revolution circulated - from Marrast, the républicain en gants jaunes [Republican in yellow gloves], who disguised himself as old Bailly, down to the adventurer who hides his trivial and repulsive features behind the iron death mask of Napoleon. A whole nation, which thought it had acquired an accelerated power of motion by means of a revolution, suddenly finds itself set back into a defunct epoch, and to remove any doubt about the relapse, the old dates arise again - the old chronology, the old names, the old edicts, which had long since become a subject of antiquarian scholarship, and the old minions of the law who had seemed long dead. The nation feels like the mad Englishman in Bedlam ${ }^{3}$ who thinks he is living in the time of the old Pharaohs and daily bewails the hard labor he must perform in the Ethiopian gold mines, immured in this subterranean prison, a pale lamp fastened to his head, the overseer of the slaves behind him with a long whip, and at the exits a confused welter of barbarian war slaves who understand neither the forced laborers nor each other, since they speak no common language. "And all this," sighs the mad Englishman, "is expected of me, a freeborn Briton, in order to make gold for the Pharaohs." "In order to pay the debts of the Bonaparte family," sighs the French nation. The Englishman, so long as he was not in his right mind, could not get rid of his idée fixé of mining gold. The French, so long as they were engaged in revolution, could not get rid of the memory of Napoleon, as the election of December 10 [1848, when Louis Bonaparte was elected President of the French Republic by plebiscite.] was proved. They longed to return from the perils of revolution to the fleshpots of Egypt ${ }^{4}$, and December 2, 1851 [The date of the coup d'état by Louis Bonaparte], was the answer. Now they have not only a caricature of the old Napoleon, but the old Napoleon himself, caricatured as he would have to be in the middle of the nineteenth century.

The social revolution of the nineteenth century cannot take its poetry from the past but only from the future. It cannot begin with itself before it has stripped away all superstition about the past. The former revolutions required recollections of past world history in order to smother their own content. The revolution of the nineteenth century must let the dead bury their dead in order to arrive at its own content. There the phrase went beyond the content - here the content goes beyond the phrase.

The February Revolution was a surprise attack, a seizing of the old society unaware, and the people proclaimed this unexpected stroke a deed of world importance, ushering in a new epoch. On December 2 the February Revolution is conjured away as a cardsharp's trick, and what seems overthrown is no longer the monarchy but the liberal concessions that had been wrung from it through centuries of struggle. Instead of society having conquered a new content for itself, it seems that the state has only returned to its oldest form, to a shamelessly simple rule by the sword and the monk's cowl. This is the answer to the coup de main [unexpected stroke] of February, 1848 , given by the coup de tête [rash act] of December, 1851. Easy come, easy go. Meantime, the interval did not pass unused. During 1848-51 French society, by an abbreviated revolutionary method, caught up with the studies and experiences which in a regular, so to speak, textbook course of development would have preceded the February Revolution, if the latter were to be more than a mere ruffling of the surface. Society seems now to have retreated to behind its starting point; in truth, it has first to create for itself the revolutionary point of departure - the situation, the relations, the conditions under which alone modern revolution becomes serious.

Bourgeois revolutions, like those of the eighteenth century, storm more swiftly from success to success, their dramatic effects outdo each other, men and things seem set in sparkling diamonds, ecstasy is the order of the day - but they are short-lived, soon they have reached their zenith, and a long Katzenjammer [cat's winge] takes hold of society before it learns to assimilate the results 
of its storm-and-stress period soberly. On the other hand, proletarian revolutions, like those of the nineteenth century, constantly criticize themselves, constantly interrupt themselves in their own course, return to the apparently accomplished, in order to begin anew; they deride with cruel thoroughness the half-measures, weaknesses, and paltriness of their first attempts, seem to throw down their opponents only so the latter may draw new strength from the earth and rise before them again more gigantic than ever, recoil constantly from the indefinite colossalness of their own goals - until a situation is created which makes all turning back impossible, and the conditions themselves call out:

Hic Rhodus, hic salta!

[Here is the rose, here dance! ${ }^{5}$

For the rest, every fair observer, even if he had not followed the course of French developments step by step, must have had a presentiment of the imminence of an unheard-of disgrace for the revolution. It was enough to hear the complacent yelps of victory with which the democrats congratulated each other on the expectedly gracious consequences of the second Sunday in May, 1852. [day of elections - Louis Bonaparte's term was expired] In their minds that second Sunday of May had become a certain idea, a dogma, like the day of Christ's reappearance and the beginning of the millennium in the minds of the Chiliasts ${ }^{6}$. As always, weakness had taken refuge in a belief in miracles, believed the enemy to be overcome when he was only conjured away in imagination, and lost all understanding of the present in an inactive glorification of the future that was in store for it and the deeds it had in mind but did not want to carry out yet. Those heroes who seek to disprove their demonstrated incapacity - by offering each other their sympathy and getting together in a crowd - had tied up their bundles, collected their laurel wreaths in advance, and occupied themselves with discounting on the exchange market the republics in partibus [i.e., in name only] for which they had already providently organized the government personnel with all the calm of their unassuming disposition. December 2 struck them like a thunderbolt from a clear sky, and those who in periods of petty depression gladly let their inner fears be drowned by the loudest renters will perhaps have convinced themselves that the times are past when the cackle of geese could save the Capitol. ${ }^{7}$

The constitution, the National Assembly, the dynastic parties, the blue and red republicans, the heroes of Africa, the thunder from the platform, the sheet lightning of the daily press, the entire literature, the political names and the intellectual reputations, the civil law and the penal code, liberté, egalité, fraternité, and the second Sunday in May, 1852 - all have vanished like a phantasmagoria before the spell of a man whom even his enemies do not make out to be a sorcerer. Universal suffrage seems to have survived only for the moment, so that with its own hand it may make its last will and testament before the eyes of all the world and declare in the name of the people itself: "All that exists deserves to perish.”[From Goethe's Faust, Part One.]

It is not enough to say, as the French do, that their nation was taken unawares. Nations and women are not forgiven the unguarded hour in which the first adventurer who came along could violate them. Such turns of speech do not solve the riddle but only formulate it differently. It remains to be explained how a nation of thirty-six millions can be surprised and delivered without resistance into captivity by three knights of industry.

Let us recapitulate in general outline the phases that the French Revolution went through from February 24, 1848, to December, 1851.

Three main periods are unmistakable: the February period; the period of the constitution of the republic or the Constituent National Assembly - May 1848 to May 28 1849; and the period of the constitutional republic or the Legislative National Assembly - May 281849 to December 21851.

The first period - from February 24, the overthrow of Louis Philippe, to May 4, 1848, the meeting of the Constituent Assembly - the February period proper, may be designated as the prologue of the revolution. Its character was officially expressed in the fact that the government it 
improvised itself declared that it was provisional, and like the government, everything that was mentioned, attempted, or enunciated during this period proclaimed itself to be only provisional. Nobody and nothing ventured to lay any claim to the right of existence and of real action. All the elements that had prepared or determined the revolution - the dynastic opposition, the republican bourgeoisie, the democratic-republican petty bourgeoisie, and the social-democratic workers, provisionally found their place in the February government.

It could not be otherwise. The February days originally intended an electoral reform by which the circle of the politically privileged among the possessing class itself was to be widened and the exclusive domination of the aristocracy of finance overthrown. When it came to the actual conflict, however - when the people mounted the barricades, the National Guard maintained a passive attitude, the army offered no serious resistance, and the monarchy ran away - the republic appeared to be a matter of course. Every party construed it in its own way. Having secured it arms in hand, the proletariat impressed its stamp upon it and proclaimed it to be a social republic. There was thus indicated the general content of the modern revolution, a content which was in most singular contradiction to everything that, with the material available, with the degree of education attained by the masses, under the given circumstances and relations, could be immediately realized in practice. On the other hand, the claims of all the remaining elements that had collaborated in the February Revolution were recognized by the lion's share they obtained in the government. In no period, therefore, do we find a more confused mixture of high-flown phrases and actual uncertainty and clumsiness, of more enthusiastic striving for innovation and more deeply rooted domination of the old routine, of more apparent harmony of the whole of society; and more profound estrangement of its elements. While the Paris proletariat still reveled in the vision of the wide prospects that had opened before it and indulged in seriously meant discussions of social problems, the old powers of society had grouped themselves, assembled, reflected, and found unexpected support in the mass of the nation, the peasants and petty bourgeois, who all at once stormed onto the political stage after the barriers of the July Monarchy had fallen.

The second period, from May 4, 1848, to the end of May, 1849, is the period of the constitution, the foundation, of the bourgeois republic. Immediately after the February days not only had the dynastic opposition been surprised by the republicans and the republicans by the socialists, but all France by Paris. The National Assembly, which met on May 4, 1848, had emerged from the national elections and represented the nation. It was a living protest against the pretensions of the February days and was to reduce the results of the revolution to the bourgeois scale. In vain the Paris proletariat, which immediately grasped the character of this National Assembly, attempted on May 15, a few days after it met, to negate its existence forcibly, to dissolve it, to disintegrate again into its constituent parts the organic form in which the proletariat was threatened by the reacting spirit of the nation. As is known, May 15 had no other result but that of removing Blanqui and his comrades - that is, the real leaders of the proletarian party - from the public stage for the entire duration of the cycle we are considering.

The bourgeois monarchy of Louis Philippe can be followed only by a bourgeois republic; that is to say, whereas a limited section of the bourgeoisie ruled in the name of the king, the whole of the bourgeoisie will now rule in the name of the people. The demands of the Paris proletariat are utopian nonsense, to which an end must be put. To this declaration of the Constituent National Assembly the Paris proletariat replied with the June insurrection, the most colossal event in the history of European civil wars. The bourgeois republic triumphed. On its side stood the aristocracy of finance, the industrial bourgeoisie, the middle class, the petty bourgeois, the army, the lumpen proletariat organized as the Mobile Guard, the intellectual lights, the clergy, and the rural population. On the side of the Paris proletariat stood none but itself. More than three thousand insurgents were butchered after the victory, and fifteen thousand were deported without trial. With this defeat the proletariat passes into the background on the revolutionary stage. It 
attempts to press forward again on every occasion, as soon as the movement appears to make a fresh start, but with ever decreased expenditure of strength and always slighter results. As soon as one of the social strata above it gets into revolutionary ferment, the proletariat enters into an alliance with it and so shares all the defeats that the different parties suffer, one after another. But these subsequent blows become the weaker, the greater the surface of society over which they are distributed. The more important leaders of the proletariat in the Assembly and in the press successively fall victim to the courts, and ever more equivocal figures come to head it. In part it throws itself into doctrinaire experiments, exchange banks and workers' associations, hence into a movement in which it renounces the revolutionizing of the old world by means of the latter's own great, combined resources, and seeks, rather, to achieve its salvation behind society's back, in private fashion, within its limited conditions of existence, and hence necessarily suffers shipwreck. It seems to be unable either to rediscover revolutionary greatness in itself or to win new energy from the connections newly entered into, until all classes with which it contended in June themselves lie prostrate beside it. But at least it succumbs with the honors of the great, world-historic struggle; not only France, but all Europe trembles at the June earthquake, while the ensuing defeats of the upper classes are so cheaply bought that they require barefaced exaggeration by the victorious party to be able to pass for events at all, and become the more ignominious the further the defeated party is removed from the proletarian party.

The defeat of the June insurgents, to be sure, had now prepared, had leveled the ground on which the bourgeois republic could be founded and built, but it had shown at the same time that in Europe the questions at issue are other than that of "republic or monarchy." It had revealed that here "bourgeois republic" signifies the unlimited despotism of one class over other classes. It had proved that in countries with an old civilization, with a developed formation of classes, with modern conditions of production, and with an intellectual consciousness in which all traditional ideas have been dissolved by the work of centuries, the republic signifies in general only the political form of revolution of bourgeois society and not its conservative form of life - as, for example, in the United States of North America, where, though classes already exist, they have not yet become fixed, but continually change and interchange their elements in constant flux, where the modern means of production, instead of coinciding with a stagnant surplus population, rather compensate for the relative deficiency of heads and hands, and where, finally, the feverish, youthful movement of material production, which has to make a new world of its own, has neither time nor opportunity left for abolishing the old world of ghosts.

During the June days all classes and parties had united in the party of Order against the proletarian class as the party of anarchy, of socialism, of communism. They had "saved" society from "the enemies of society." They had given out the watchwords of the old society, "property, family, religion, order," to their army as passwords and had proclaimed to the counterrevolutionary crusaders: "In this sign thou shalt conquer!" From that moment, as soon as one of the numerous parties which gathered under this sign against the June insurgents seeks to hold the revolutionary battlefield in its own class interest, it goes down before the cry: "property, family, religion, order." Society is saved just as often as the circle of its rulers contracts, as a more exclusive interest is maintained against a wider one. Every demand of the simplest bourgeois financial reform, of the most ordinary liberalism, of the most formal republicanism, of the most shallow democracy, is simultaneously castigated as an "attempt on society" and stigmatized as "socialism." And finally the high priests of "religion and order" themselves are driven with kicks from their Pythian tripods, hauled out of their beds in the darkness of night, put in prison vans, thrown into dungeons or sent into exile; their temple is razed to the ground, their mouths are sealed, their pens broken, their law torn to pieces in the name of religion, of property, of the family, of order. Bourgeois fanatics for order are shot down on their balconies by mobs of drunken soldiers, their domestic sanctuaries profaned, their houses bombarded for amusement in the name of property, of the family, of religion, and of order. Finally, the scum of bourgeois 
society forms the holy phalanx of order and the hero Crapulinski [a character from Heine's poem "The Two Knights," a dissolute aristocrat.] installs himself in the Tuileries as the "savior of society."

\footnotetext{
${ }^{1}$ Marx never believed that "history repeats itself," but in a famous quote he said:

"Hegel remarks somewhere that all great world-historic facts and personages appear, so to speak, twice. He forgot to add: the first time as tragedy, the second time as farce." [Marx, 18th Brumaire of Louis Bonapatre, Chapter 1.]
}

This seems to come from Engels' letter to Marx of 3 December 1851:

"it really seems as though old Hegel, in the guise of the World Spirit, were directing history from the grave and, with the greatest conscientiousness, causing everything to be re-enacted twice over, once as grand tragedy and the second time as rotten farce, Caussidière for Danton, L. Blanc for Robespierre, Barthélemy for Saint-Just, Flocon for Carnot, and the moon-calf together with the first available dozen debt-encumbered lieutenants for the little corporal and his band of marshals. Thus the 18th Brumaire would already be upon us."

- words quoted almost verbatim by Marx in Eighteenth of Louis Bonapartre.

Marx makes similar points in Critique of Hegel's Philosophy of Right, Introduction.

Possible sources in Hegel are The Philosophy of Right, §347 and The Philosophy of History, §32-33 though another version of this work published as Introduction to The Philosophy of History, published in 1837, said:

"A coup d'état is sanctioned as it were in the opinion of the people if it is repeated. Thus, Napoleon was defeated twice and twice the Bourbons were driven out. Through repetition, what at the beginning seemed to be merely accidental and possible, becomes real and established."

but this is hardly the point being made by Marx. See The Philosophy of History, where Hegel contrasts Nature, where "there is nothing new under the Sun," with History where there is always Development.

${ }^{2}$ Montagne (the Mountain) - representatives in the Constituent and subsequently in the Legislative Assembly of a bloc of democrats and petty-bourgeois socialists grouped round the newspaper La Réforme. They called themselves Montagnards or the Mountain by analogy with the Montagnards in the Convention of 1792-94.

${ }^{3}$ Bedlam was an infamous lunatic asylum in England.

${ }^{4}$ The expression, "to sigh for the flesh-pots of Egypt" is taken from the biblical legend, according to which during the exodus of the Israelites from Egypt the faint-hearted among them wished that they had died when they sat by the flesh-pots of Egypt, rather than undergo their present trials through the desert.

${ }^{5}$ Latin, usually translated: "Rhodes is here, here is where you jump!"

The well-known but little understood maxim originates from the traditional Latin translation of the punchline from Aesop's fable The Boastful Athlete which has been the subject of some mistranslations.

In Greek, the maxim reads:

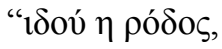

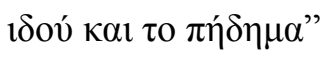

The story is that an athlete boasts that when in Rhodes, he performed a stupendous jump, and that there were witnesses who could back up his story. A bystander then remarked, 'Alright! Let's say this is Rhodes, demonstrate the jump here and now.' The fable shows that people must be known by their 
deeds, not by their own claims for themselves. In the context in which Hegel uses it, this could be taken to mean that the philosophy of right must have to do with the actuality of modern society ("What is rational is real; what is real is rational"), not the theories and ideals that societies create for themselves, or some ideal counterposed to existing conditions: "To apprehend what is is the task of philosophy," as Hegel goes on to say, rather than to "teach the world what it ought to be."

The epigram is given by Hegel first in Greek, then in Latin (in the form "Hic Rhodus, hic saltus"), in the Preface to the Philosophy of Right, and he then says: "With little change, the above saying would read (in German): "Hier ist die Rose, hier tanze":

"Here is the rose, dance here"

This is taken to be an allusion to the 'rose in the cross' of the Rosicrucians (who claimed to possess esoteric knowledge with which they could transform social life), implying that the material for understanding and changing society is given in society itself, not in some other-worldly theory, punning first on the Greek (Rhodos $=$ Rhodes, rhodon $=$ rose), then on the Latin (saltus $=$ jump [noun], salta $=$ dance [imperative $]$ ).

In 18th Brumaire of Louis Bonaparte, Marx quotes the maxim, first giving the Latin, in the form:

"Hic Rhodus, hic salta!",

- a garbled mixture of Hegel's two versions (salta $=$ dance! instead of saltus $=$ jump), and then immediately adds: "Hier ist die Rose, hier tanze!", as if it were a translation, which it cannot be, since Greek Rhodos, let alone Latin Rhodus, does not mean "rose". But Marx does seem to have retained Hegel's meaning, as it is used in the observation that, overawed by the enormity of their task, people do not act until:

"a situation is created which makes all turning back impossible,

and the conditions themselves call out: Here is the rose, here dance!."

and one is reminded of Marx's maxim in the Preface to the Critique of Political Economy:

"Mankind thus inevitably sets itself only such tasks as it is able to solve, since closer examination will always show that the problem itself arises only when the material conditions for its solution are already present or at least in the course of formation!."

So Marx evidently supports Hegel's advice that we should not "teach the world what it ought to be", but he is giving a more active spin than Hegel would when he closes the Preface observing:

"For such a purpose philosophy at least always comes too late....

The owl of Minerva, takes its flight only when the shades of night are gathering."

Marx also uses the phrase, but with salta instead of saltus, but with more or less the meaning intended by Aesop in Chapter 5 of Capital.

${ }^{6}$ Chiliasts (from the Greek word chilias - a thousand): preachers of a mystical religious doctrine concerning the second coming of Christ and the establishment of the millennium when justice, universal equality and prosperity would be triumphant.

${ }^{7}$ Capitol: A hill in Rome, a fortified citadel where the temples of Jupiter, Juno and other gods were built. According to a legend, Rome was saved in 390 B.C.E. from an invasion of the Gauls, due to the cackling of geese from Juno's temple which awakened the sleeping guards of the Capitol. 


\section{II}

Let us pick up the threads of the development once more.

The history of the Constituent National Assembly since the June days is the history of the domination and the disintegration of the republican faction of the bourgeoisie, of the faction known by the names of tricolor republicans, pure republicans, political republicans, formalist republicans, etc.

Under the bourgeois monarchy of Louis Philippe it had formed the official republican opposition and consequently a recognized component part of the political world of the day. It had its representatives in the Chambers and a considerable sphere of influence in the press. Its Paris organ, the National, was considered just as respectable in its way as theJournal des Débats. Its character corresponded to this position under the constitutional monarchy. It was not a faction of the bourgeoisie held together by great common interests and marked off by specific conditions of production. It was a clique of republican-minded bourgeois, writers, lawyers, officers, and officials that owed its influence to the personal antipathies of the country to Louis Philippe, to memories of the old republic, to the republican faith of a number of enthusiasts, above all, however, to French nationalism, whose hatred of the Vienna treaties ${ }^{1}$ and of the alliance with England it stirred up perpetually. A large part of the following the National had under Louis Philippe was due to this concealed imperialism, which could consequently confront it later, under the republic, as a deadly rival in the person of Louis Bonaparte. It fought the aristocracy of finance, as did all the rest of the bourgeois opposition. Polemics against the budget, which in France were closely connected with fighting the aristocracy of finance, procured popularity too cheaply and material for puritanical leading articles too plentifully not to be exploited. The industrial bourgeoisie was grateful to it for its slavish defense of the French protectionist system, which it accepted, however, more on national grounds than on grounds of national economy; the bourgeoisie as a whole, for its vicious denunciation of communism and socialism. For the rest, the party of the National was purely republican; that is, it demanded a republican instead of a monarchist form of bourgeois rule and, above all, the lion's share of this rule. About the conditions of this transformation it was by no means clear in its own mind. On the other hand, what was clear as daylight to it, and was publicly acknowledged at the reform banquets in the last days of Louis Philippe, was its unpopularity with the democratic petty bourgeois, and in particular with the revolutionary proletariat. These pure republicans, as is indeed the way with pure republicans, were already at the point of contenting themselves in the first instance with a regency of the Duchess of Orleans ${ }^{2}$ when the February Revolution broke out and assigned their best-known representatives a place in the Provisional Government. From the start they naturally had the confidence of the bourgeoisie and a majority in the Constituent National Assembly. The socialist elements of the Provisional Government were excluded forthwith from the Executive Commission which the National Assembly formed when it met, and the party of the National took advantage of the outbreak of the June insurrection to discharge the Executive Commission ${ }^{3}$ also, and therewith to get rid of its closest rivals, the petty-bourgeois, or democratic, republicans (Ledru-Rollin, etc.). Cavaignac, the general of the bourgeois-republican part who commanded the June massacre, took the place of the Executive Commission with a sort of dictatorial power. Marrast, former editor in chief of the National, became the perpetual president of the Constituent National Assembly, and the ministries, as well as all other important posts, fell to the portion of the pure republicans.

The republican bourgeois faction, which had long regarded itself as the legitimate heir of the July Monarchy, thus found its fondest hopes exceeded; it attained power, however, not as it had dreamed under Louis Philippe, through a liberal revolt of the bourgeoisie against the throne, but through a rising of the proletariat against capital, a rising laid low with grapeshot. What it had 
conceived as the most revolutionary event turned out in reality to be the most counterrevolutionary. The fruit fell into its lap, but it fell from the tree of knowledge, not from the tree of life.

The exclusive rule of the bourgeois republicans lasted only from June 24 to December 10, 1848. It is summed up in the drafting of a republican constitution and in the state of siege of Paris.

The new constitution was at bottom only the republicanized edition of the constitutional Charter of $1830 .{ }^{4}$ The narrow electoral qualification of the July Monarchy, which excluded even a large part of the bourgeoisie from political rule, was incompatible with the existence of the bourgeois republic. In lieu of this qualification, the February Revolution had at once proclaimed direct universal suffrage. The bourgeois republicans could not undo this event. They had to content themselves with adding the limiting proviso of a six months' residence in the constituency. The old organization of the administration, the municipal system, the judicial system, the army, etc., continued to exist inviolate, or, where the constitution changed them, the change concerned the table of contents, not the contents; the name, not the subject matter.

The inevitable general staff of the liberties of 1848, personal liberty, liberty of the press, of speech, of association, of assembly, of education and religion, etc., received a constitutional uniform which made them invulnerable. For each of these liberties is proclaimed as the absolute right of the French citoyen, but always with the marginal note that it is unlimited so far as it is not limited by the "equal rights of others and the public safety" or by "laws" which are intended to mediate just this harmony of the individual liberties with one another and with the public safety. For example:

"The citizens have the right of association, of peaceful and unarmed assembly, of petition and of expressing their opinions, whether in the press or in any other way. The enjoyment of these rights has no limit save the equal rights of others and the public safety."

"Education is free. Freedom of education shall be enjoyed under the conditions fixed by law and under the supreme control of the state."

"The home of every citizen is inviolable except in the forms prescribed by law."

The constitution, therefore, constantly refers to future organic laws which are to put into affect those marginal notes and regulate the enjoyment of these unrestricted liberties in such manner that they will collide neither with one another nor with the public safety. And later these organic laws were brought into being by the friends of order and all those liberties regulated in such manner that the bourgeoisie in its enjoyment of them finds itself unhindered by the equal rights of the other classes. Where it forbids these liberties entirely to "the others," or permits enjoyment of them under conditions that are just so many police traps, this always happens solely in the interest of "public safety" - that is, the safety of the bourgeoisie - as the constitution prescribes. In the sequel, both sides accordingly appeal with complete justice to the constitution: the friends of order, who abrogated all these liberties, as well as the democrats, who demanded all of them. For each paragraph of the constitution contains its own antithesis, its own upper and lower house, namely, liberty in the general phrase, abrogation of liberty in the marginal note. Thus so long as the name of freedom was respected and only its actual realization prevented, of course in a legal way, the constitutional existence of liberty remained intact, inviolate, however mortal the blows dealt to its existence in actual life.

This constitution, made inviolable in so ingenious a manner, was nevertheless, like Achilles, vulnerable in one point - not in the heel, but in the head, or rather in the two heads it wound up with: the Legislative Assembly on the one hand, the President on the other. Glance through the constitution and you will find that only the paragraphs in which the relationship of the President to the Legislative Assembly is defined are absolute, positive, noncontradictory, and cannot be distorted. For here it was a question of the bourgeois republicans safeguarding themselves. 
Articles 45-70 of the Constitution are so worded that the National Assembly can remove the President constitutionally, whereas the President can remove the National Assembly only unconstitutionally, only by setting aside the constitution itself. Here, therefore, it challenges its forcible destruction. It not only sanctifies the division of powers, like the Charter of 1830, it widens it into an intolerable contradiction. The play of the constitutional powers, as Guizot termed the parliamentary squabble between the legislative and executive power, is in the constitution of 1848 continually played va-banque [staking all]. On one side are seven hundred and fifty representatives of the people, elected by universal suffrage and eligible for re-election; they form an uncontrollable, indissoluble, indivisible National Assembly, a National Assembly that enjoys legislative omnipotence, decides in the last instance on war, peace, and commercial treaties, alone possesses the right of amnesty, and, by its permanence, perpetually holds the front of the stage. On the other side is the President, with all the attributes of royal power, with authority to appoint and dismiss his ministers independently of the National Assembly, with all the resources of the executive power in his hands, bestowing all posts and disposing thereby in France of the livelihoods of at least a million and a half people, for so many depend on the five hundred thousand officials and officers of every rank. He has the whole of the armed forces behind him. He enjoys the privilege of pardoning individual criminals, of suspending National Guards, of discharging, with the concurrence of the Council of State, general, cantonal, and municipal councils elected by the citizens themselves. Initiative and direction are reserved to him in all treaties with foreign countries. While the Assembly constantly performs on the boards and is exposed to daily public criticism, he leads a secluded life in the Elysian Fields, and that with Article 45 of the constitution before his eyes and in his heart, crying to him daily: "Frere, il faut mourir!" ['Brother, one must die!'] $]^{5}$ Your power ceases on the second Sunday of the lovely month of May in the fourth year after your election! Then your glory is at an end, the piece is not played twice, and if you have debts, look to it quickly that you pay them off with the 600,000 francs granted you by the constitution, unless, perchance, you prefer to go to Clichy ${ }^{6}$ on the second Monday of the lovely month of May! Thus, whereas the constitution assigns power to the President, it seeks to secure moral power for the National Assembly. Apart from the fact that it is impossible to create a moral power by paragraphs of law, the constitution here abrogates itself once more by having the President elected by all Frenchmen through direct suffrage. While the votes of France are split up among the seven hundred and fifty members of the National Assembly, they are here, on the contrary, concentrated on a single individual. While each separate representative of the people represents only this or that party, this or that town, this or that bridgehead, or even only the mere necessity of electing someone as the seven hundred and fiftieth, without examining too closely either the cause or the man, he is the elect of the nation and the act of his election is the trump that the sovereign people plays once every four years. The elected National Assembly stands in a metaphysical relation, but the elected President in a personal relation, to the nation. The National Assembly, indeed, exhibits in its individual representatives the manifold aspects of the national spirit, but in the President this national spirit finds its incarnation. As against the Assembly, he possesses a sort of divine right; he is President by the grace of the people.

Thetis, the sea goddess, prophesied to Achilles that he would die in the bloom of youth. The constitution, which, like Achilles, had its weak spot, also had, like Achilles, a presentiment that it must go to an early death. It was sufficient for the constitution-making pure republicans to cast a glance from the lofty heaven of their ideal republic at the profane world to perceive how the arrogance of the royalists, the Bonapartists, the democrats, the communists, as well as their own discredit, grew daily in the same measure as they approached the completion of their great legislative work of art, without Thetis on this account having to leave the sea and communicate the secret to them. They sought to cheat destiny by a catch in the constitution, through Article III according to which every motion for a revision of the constitution must be supported by at least 
three-quarters of the votes, cast in three successive debates with an entire month between each, with the added proviso that not less than five hundred members of the National Assembly must vote. Thereby they merely made the impotent attempt to continue exercising a power - when only a parliamentary minority, as which they already saw themselves prophetically in their mind's eye - a power which at that time, when they commanded a parliamentary majority and all the resources of governmental authority, was daily slipping more and more from their feeble hands.

Finally the constitution, in a melodramatic paragraph, entrusts itself "to the vigilance and the patriotism of the whole French people and every single Frenchman," after it has previously entrusted in another paragraph the "vigilant" and "patriotic" to the tender, most painstaking care of the High Court of Justice, the haute cour it invented for the purpose.

Such was the Constitution of 1848 , which on December 2, 1851, was not overthrown by a head, but fell down at the touch of a mere hat; this hat, to be sure, was a three-cornered Napoleonic hat.

While the bourgeois republicans in the Assembly were busy devising, discussing, and voting this constitution, Cavaignac outside the Assembly maintained the state of siege of Paris. The state of siege of Paris was the midwife of the Constituent Assembly in its travail of republican creation. If the constitution is subsequently put out of existence by bayonets, it must not be forgotten that it was likewise by bayonets, and these turned against the people, that it had to be protected in its mother's womb and by bayonets that it had to be brought into existence. The forefathers of the "respectable republicans" had sent their symbol, the tricolor, on a tour around Europe. They themselves in turn produced an invention that of itself made its way over the whole Continent, but returned to France with ever renewed love until it has now become naturalized in half her departments - the state of siege. A splendid invention, periodically employed in every ensuing crisis in the course of the French Revolution. But barrack and bivouac, which were thus periodically laid on French society's head to compress its brain and render it quiet; saber and musket, which were periodically allowed to act as judges and administrators, as guardians and censors, to play policeman and do night watchman's duty; mustache and uniform, which were periodically trumpeted forth as the highest wisdom of society and as its rector - were not barrack and bivouac, saber and musket, mustache and uniform finally bound to hit upon the idea of instead saving society once and for all by proclaiming their own regime as the highest and freeing civil society completely from the trouble of governing itself? Barrack and bivouac, saber and musket, mustache and uniform were bound to hit upon this idea all the more as they might then also expect better cash payment for their higher services, whereas from the merely periodic state of siege and the transient rescues of society at the bidding of this or that bourgeois faction, little of substance was gleaned save some killed and wounded and some friendly bourgeois grimaces. Should not the military at last one day play state of siege in their own interest and for their own benefit, and at the same time besiege the citizens' purses? Moreover, be it noted in passing, one must not forget that Colonel Bernard, the same military commission president who under Cavaignac had fifteen thousand insurgents deported without trial, is at this moment again at the head of the military commissions active in Paris.

Whereas with the state of siege in Paris, the respectable, the pure republicans planted the nursery in which the praetorians of December 2, 1851, were to grow up, they on the other hand deserve praise for the reason that, instead of exaggerating the national sentiment as under Louis Philippe, they now, when they had command of the national power, crawled before foreign countries, and instead of setting Italy free, let her be reconquered by Austrians and Neapolitans. ${ }^{7}$ Louis Bonaparte's election as President on December 10, 1848, put an end to the dictatorship of Cavaignac and to the Constituent Assembly.

In Article 44 of the Constitution it is stated:

"The President of the French Republic must never have lost his status of French citizen." 
The first President of the French Republic, L. N. Bonaparte, had not merely lost his status of French citizen, had not only been an English special constable, he was even a naturalized Swiss. ${ }^{8}$

I have worked out elsewhere the significance of the election of December 10. I will not revert to it here. It is sufficient to remark here that it was a reaction of the peasants, who had had to pay the costs of the February Revolution, against the remaining classes of the nation; a reaction of the country against the town. It met with great approval in the army, for which the republicans of the National had provided neither glory nor additional pay; among the big bourgeoisie, which hailed Bonaparte as a bridge to monarchy, among the proletarians and petty bourgeois, who hailed him as a scourge for Cavaignac. I shall have an opportunity later of going more closely into the relationship of the peasants to the French Revolution.

The period from December 20, 1848, until the dissolution of the Constituent Assembly in May, 1849 , comprises the history of the downfall of the bourgeois republicans. After having founded a republic for the bourgeoisie, driven the revolutionary proletariat out of the field, and reduced the democratic petty bourgeoisie to silence for the time being, they are themselves thrust aside by the mass of the bourgeoisie, which justly impounds this republic as its property. This bourgeois mass was, however, royalist. One section of it, the large landowners, had ruled during the Restoration and was accordingly Legitimist. The other, the aristocrats of finance and big industrialists, had ruled during the July Monarchy and was consequently Orleanist. The high dignitaries of the army, the university, the church, the bar, the academy, and the press were to be found on either side, though in various proportions. Here, in the bourgeois republic, which bore neither the name Bourbon nor the name Orleans, but the name capital, they had found the form of state in which they could rule conjointly. The June insurrection had already united them in the party of Order. Now it was necessary, in the first place, to remove the coterie of bourgeois republicans who still occupied the seats of the National Assembly. Just as brutal as these pure republicans had been in their misuse of physical force against the people, just as cowardly, mealy-mouthed, brokenspirited, and incapable of fighting were they now in their retreat, when it was a question of maintaining their republicanism and their legislative rights against the executive power and the royalists. I need not relate here the ignominious history of their dissolution. They did not succumb; they passed out of existence. Their history has come to an end forever, and, both inside and outside the Assembly, they figure in the following period only as memories, memories that seem to regain life whenever the mere name republic is once more the issue and as often as the revolutionary conflict threatens to sink down to the lowest level. I may remark in passing that the journal which gave its name to this party, the National, was converted to socialism in the following period.

Before we finish with this period we must still cast a retrospective glance at the two powers, one of which annihilated the other on December 2, 1851, whereas from December 20, 1848, until the exit of the Constituent Assembly, they had lived in conjugal relations. We mean Louis Bonaparte, on the one hand, and the part of the coalesced royalists, the party of Order, of the big bourgeoisie, on the other. On acceding to the presidency, Bonaparte at once formed a ministry of the party of Order, at the head of which he placed Odilon Barrot, the old leader, nota bene, of the most liberal faction of the parliamentary bourgeoisie. M. Barrot had at last secured the ministerial portfolio whose image had haunted him since 1830, and what is more, the premiership in the ministry; but not, as he had imagined under Louis Philippe, as the most advanced leader of the parliamentary opposition, but with the task of putting a parliament to death, and as the confederate of all his archenemies, Jesuits and Legitimists. He brought the bride home at last, but only after she had been prostituted. Bonaparte seemed to efface himself completely. This party acted for him.

The very first meeting of the council of ministers resolved on the expedition to Rome, which, it was agreed, should be undertaken behind the back of the National Assembly and the means for which were to be wrested from it under false pretenses. Thus they began by swindling the 
National Assembly and secretly conspiring with the absolutist powers abroad against the revolutionary Roman republic.

In the same manner and with the same maneuvers Bonaparte prepared his coup of December 2 against the royalist Legislative Assembly and its constitutional republic. Let us not forget that the same party which formed Bonaparte's ministry on December 20, 1848, formed the majority of the Legislative National Assembly on December 2, 1851.

In August the Constituent Assembly had decided to dissolve only after it had worked out and promulgated a whole series of organic laws that were to supplement the constitution. On January 6, 1849, the party of Order had a deputy named Rateau move that the Assembly should let the organic laws go and rather decide on its own dissolution. Not only the ministry, with Odilon Barrot at its head, but all the royalist members of the National Assembly told it in bullying accents then that its dissolution was necessary for the restoration of credit, for the consolidation of order, for putting an end to the indefinite provisional arrangements and establishing a definitive state of affairs; that it hampered the productivity of the new government and sought to prolong its existence merely out of malice; that the country was tired of it. Bonaparte took note of all this invective against the legislative power, learned it by heart, and proved to the parliamentary royalists, on December 2, 1851, that he had learned from them. He repeated their own catchwords against them.

The Barrot Ministry and the party of Order went further. They caused petitions to the National Assembly to be made throughout France, in which this body was politely requested to decamp. They thus led the unorganized popular masses into the fire of battle against the National Assembly, the constitutionally organized expression of the people. They taught Bonaparte to appeal against the parliamentary assemblies to the people. At length, on January 29, 1849, the day had come on which the Constituent Assembly was to decide concerning its own dissolution. The National Assembly found the building where its sessions were held occupied by the military; Changarnier, the general of the party of Order, in whose hands the supreme command of the National Guard and troops of the line had been united, held a great military review in Paris, as if a battle were impending, and the royalists in coalition threateningly declared to the Constituent Assembly that force would be employed if it should prove unwilling. It was willing, and only bargained for a very short extra term of life. What was January 29 but the coup d'etat of December 2, 1851, only carried out by the royalists with Bonaparte against the republican National Assembly? The gentlemen did not observe, or did not wish to observe, that Bonaparte availed himself of January 29, 1849, to have a portion of the troops march past him in front of the Tuileries, and seized with avidity on just this first public summoning of the military power against the parliamentary power to foreshadow Caligula. They, to be sure, saw only their Changarnier.

A motive that particularly actuated the party of Order in forcibly cutting short the duration of the Constituent Assembly's life was the organic laws supplementing the constitution, such as the law on education, the law on religious worship, etc. To the royalists in coalition it was most important that they themselves should make these laws and not let them be made by the republicans, who had grown mistrustful. Among these organic laws, however, was also a law on the responsibility of the President of the Republic. In 1851 the Legislative Assembly was occupied with the drafting of just such a law, when Bonaparte anticipated this coup with the coup of December 2. What would the royalists in coalition not have given in their winter election campaign of 1851 to have found the Responsibility Law ready to hand, and drawn up, at that, by a mistrustful, hostile, republican Assembly!

After the Constituent Assembly had itself shattered its last weapon on January 29, 1849, the Barrot Ministry and the friends of order hounded it to death, left nothing undone that could humiliate it, and wrested from the impotent, self-despairing Assembly laws that cost it the last remnant of respect in the eyes of the public. Bonaparte, occupied with his fixed Napoleonic idea ${ }^{9}$, 
was brazen enough to exploit publicly this degradation of the parliamentary power. For when on May 8, 1849, the National Assembly passed a vote of censure of the ministry because of the occupation of Civitavecchia by Oudinot, and ordered it to bring back the Roman expedition to its alleged purpose ${ }^{10}$ Bonaparte published the same evening in the Moniteur a letter to Oudinot in which he congratulated him on his heroic exploits and, in contrast to the ink-slinging parliamentarians, already posed as the generous protector of the army. The royalists smiled at this. They regarded him simply as their dupe. Finally, when Marrast, the President of the Constituent Assembly, believed for a moment that the safety of the National Assembly was endangered and, relying on the constitution, requisitioned a colonel and his regiment, the colonel declined, cited discipline in his support, and referred Marrast to Changarnier, who scornfully refused him with the remark that he did not like baionnettes intelligentes [intellectual bayonets]. In November, 1851, when the royalists in coalition wanted to begin the decisive struggle with Bonaparte, they sought to put through in their notorious Quaestors' Bill the principle of the direct requisition of troops by the President of the National Assembly. ${ }^{11}$ One of their generals, Le Flo, had signed the bill. In vain did Changarnier vote for it and Thiers pay homage to the farsighted wisdom of the former Constituent Assembly. The War Minister, Saint-Arnaud, answered him as Changarnier had answered Marrast - and to the acclamation of the Montagne!

Thus the party of Order, when it was not yet the National Assembly, when it was still only the ministry, had itself stigmatized the parliamentary regime. And it makes an outcry when December 2, 1851, banishes this regime from France!

We wish it a happy journey.

${ }^{1}$ The Vienna treaties-the treaties and agreements concluded at the Congress of Vienna held by European monarchs and their Ministers in 1814-15. They established the borders and status of European states after the victory, over Napoleonic France and sanctioned, contrary to the national interests and will of the peoples, the reshaping of Europe's political map and the restoration of the "legitimate" dynasties overthrown as a result of the French Revolution and the Napoleonic wars. The Vienna treaties confirmed France's territory within the borders of 1790 and the restoration of the Bourbons in France.

${ }^{2}$ On February 24, 1848 Louis Philippe abdicated in favour of his grandson, the Count of Paris. In view of the latter's minority, his mother, the Duchess of Orleans, was to assume the regency. But the King's abdication failed to halt the development of the revolution. Under pressure from the insurgent masses a Provisional Government was set up which proclaimed a republic the next day.

${ }^{3}$ The Executive Commission (Commission du pouvoir exécutif) - the Government of the French Republic set up by the Constituent Assembly on May 10, 1848 to replace the Provisional Government, which had resigned. It existed until June 24, 1848, when Cavaignac's dictatorship was established during the June proletarian uprising. Composed mostly of moderate republicans, the commission included Ledru-Rollin as a representative of the Left.

${ }^{4}$ The text of the Constitution of the French Republic was originally published in Le Moniteur universel, No. 312, November 7, 1848, and the same year it appeared as a pamphlet. Marx examined this document in 1851 in a special article entitled "The Constitution of the French Republic". In The Eighteenth Brumaire of Louis Bonaparte Marx often designates articles of this Constitution as paragraphs $(\S \S)$.

The constitutional Charter, adopted after the bourgeois revolution of 1830, was the fundamental law of the July monarchy. Nominally the Charter proclaimed the sovereign rights of the nation and restricted somewhat the king's power. But the bureaucratic and police apparatus remained intact, as did the severe laws against the working-class and democratic movement. 
5 "Frere, il faut mourir!" ("Brother, one must die!") - this is how Trappists, monks of a Catholic order, greeted each other. The order was founded in 1664 and was noted for its strict rules and the ascetic life of its members.

${ }^{6}$ Clichy - a debtors' prison in Paris from 1826 to 1867.

${ }^{7}$ This refers to the Cavaignac Government's attitude towards the new revolutionary upsurge in Italy that began in the autumn of 1848. Though Cavaignac declared a policy of non-interference, he actually rendered diplomatic aid to the ruling circles of the Kingdom of Naples and Austria in their struggle against the Italian national liberation movement. When Pius IX fled to the Neapolitan fortress of Gaeta after the popular uprising in Rome on November 16, which started a series of events that resulted in the proclamation of the Roman Republic on February 9, 1849, Cavaignac offered him asylum in France. Incited by the French Government, Pius IX called on all Catholic states on December 4, 1848 to intervene against the Roman revolutionaries, and Naples and Austria immediately responded to this call. By his policy Cavaignac in effect prepared for the dispatch of a French expeditionary corps against the Roman Republic undertaken later by President Louis Bonaparte.

${ }^{8}$ In 1832 Louis Bonaparte became a Swiss citizen in the canton of Thurgau

${ }^{9}$ An ironical allusion to Louis Bonaparte's book Des Idées apoleoniennes. which he wrote in England and published in Paris and Brussels in 1839.

${ }^{10}$ The French Government managed to get allocations from the Constituent Assembly for the dispatch to Italy of an expeditionary corps under General Oudinot in April 1849 on the pretext of defending Piedmont in its struggle against Austria, and of protecting the Roman Republic. The true aim of the expedition was intervention against the Roman Republic and restoration of the Pope's temporal power. (On this subject see also Marx's The Class Struggles in France, 1848 to 1850).

${ }^{11}$ The reference is to the Bill introduced on November 6,1851 by the royalists Lt. Flô, Baze and Panat, questors of the Legislative Assembly (deputies of the Assembly charged with economic and financial matters and safeguarding its security). It was rejected on November 17 after a heated debate, in which Thiers supported the Bill and the Bonapartist Saint-Arnaud opposed it. When the vote was taken, the Montagne supported the Bonapartists because it saw the main danger in the royalists. 


\section{III}

On May 28, 1849, the Legislative National Assembly met. On December 2, 1851, it was dispersed. This period covers the span of life of the constitutional, or parliamentary, republic.

In the first French Revolution the rule of the Constitutionalists is followed by the rule of the Girondists and the rule of the Girondists by the rule of the Jacobins. Each of these parties relies on the more progressive party for support. As soon as it has brought the revolution far enough to be unable to follow it further, still less to go ahead of it, it is thrust aside by the bolder ally that stands behind it and sent to the guillotine. The revolution thus moves along an ascending line.

It is the reverse with the Revolution of 1848. The proletarian party appears as an appendage of the petty-bourgeois-democratic party. It is betrayed and dropped by the latter on April 16, May 15, ${ }^{1}$ and in the June days. The democratic party, in its turn, leans on the shoulders of the bourgeoisrepublican party. The bourgeois republicans no sooner believe themselves well established than they shake off the troublesome comrade and support themselves on the shoulders of the party of Order. The party of Order hunches its shoulders, lets the bourgeois republicans tumble, and throws itself on the shoulders of armed force. It fancies it is still sitting on those shoulders when one fine morning it perceives that the shoulders have transformed themselves into bayonets. Each party kicks from behind at the one driving forward, and leans over in front toward the party which presses backward. No wonder that in this ridiculous posture it loses its balance and, having made the inevitable grimaces, collapses with curious gyrations. The revolution thus moves in a descending line. It finds itself in this state of retrogressive motion before the last February barricade has been cleared away and the first revolutionary authority constituted.

The period that we have before us comprises the most motley mixture of crying contradictions: constitutionalists who conspire openly against the constitution; revolutionists who are confessedly constitutional; a National Assembly that wants to be omnipotent and always remains parliamentary; a Montagne that finds its vocation in patience and counters its present defeats by prophesying future victories; royalists who form the patres conscripti [elders] of the republic and are forced by the situation to keep the hostile royal houses they adhere to abroad, and the republic, which they hate, in France; an executive power that finds its strength in its very weakness and its respectability in the contempt that it calls forth; a republic that is nothing but the combined infamy of two monarchies, the Restoration and the July Monarchy, with an imperial label - alliances whose first proviso is separation; struggles whose first law is indecision; wild, inane agitation in the name of tranquillity, most solemn preaching of tranquillity in the name of revolution - passions without truth, truths without passion; heroes without heroic deeds, history without events; development, whose sole driving force seems to be the calendar, wearying with constant repetition of the same tensions and relaxations; antagonisms that periodically seem to work themselves up to a climax only to lose their sharpness and fall away without being able to resolve themselves; pretentiously paraded exertions and philistine terror at the danger of the world's coming to an end, and at the same time the pettiest intrigues and court comedies played by the world redeemers, who in their laisser aller [letting things go] remind us less of the Day of Judgment than of the times of the Fronde [An anti-royalist movement of 1648-53] ${ }^{2}$ - the official collective genius of France brought to naught by the artful stupidity of a single individual; the collective will of the nation, as often as it speaks through universal suffrage, seeking its appropriate expression through the inveterate enemies of the interests of the masses, until at length it finds it in the self-will of a filibuster. If any section of history has been painted gray on gray, it is this. Men and events appear as reverse Schlemihls, as shadows that have lost their bodies. ${ }^{3}$ The revolution itself paralyzes its own bearers and endows only its adversaries with passionate forcefulness. When the "red specter," continually conjured up and exercised by the 
counterrevolutionaries ${ }^{4}$ finally appears, it appears not with the Phrygian cap of anarchy on its head, but in the uniform of order, in red breeches.

We have seen that the ministry which Bonaparte installed on December 20, 1848, on his Ascension Day, was a ministry of the party of Order, of the Legitimist and Orleanist coalition. This Barrot-Falloux Ministry had outlived the republican Constituent Assembly, whose term of life it had more or less violently cut short, and found itself still at the helm. Changarnier, the general of the allied royalists, continued to unite in his person the general command of the First Army Division and of the National Guard of Paris. Finally, the general elections had secured the party of Order a large majority in the National Assembly. Here the deputies and peers of Louis Philippe encountered a hallowed host of Legitimists, for whom many of the nation's ballots had become transformed into admission cards to the political stage. The Bonapartist representatives of the people were too sparse to be able to form an independent parliamentary party. They appeared merely as the mauvaise queue [evil appendage] of the party of Order. Thus the party of Order was in possession of the governmental power, the army and the legislative body, in short, of the whole of the state power; it had been morally strengthened by the general elections, which made its rule appear as the will of the people, and by the simultaneous triumph of the counterrevolution on the whole continent of Europe.

Never did a party open its campaign with greater resources or under more favorable auspices.

The shipwrecked pure republicans found that they had melted down to a clique of about fifty men in the Legislative National Assembly, the African generals Cavaignac, Lamoriciere, and Bedeau at their head. The great opposition party, however, was formed by the Montagne. The socialdemocratic party had given itself this parliamentary baptismal name. It commanded more than two hundred of the seven hundred and fifty votes of the National Assembly and was consequently at least as powerful as any one of the three factions of the party of Order taken by itself. Its numerical inferiority compared with the entire royalist coalition seemed compensated by special circumstances. Not only did the elections in the departments show that it had gained a considerable following among the rural population. It counted in its ranks almost all the deputies from Paris; the army had made a confession of democratic faith by the election of three noncommissioned officers; and the leader of the Montagne, Ledru-Rollin, in contradistinction to all the representatives of the party of Order, had been raised to the parliamentary peerage by five departments, which had pooled their votes for him. In view of the inevitable clashes of the royalists among themselves and of the whole party of Order with Bonaparte, the Montagne thus seemed to have all the elements of success before it on May 28, 1849. A fortnight later it had lost everything, honor included.

Before we pursue parliamentary history further, some remarks are necessary to avoid common misconceptions regarding the whole character of the epoch that lies before us. Looked at with the eyes of democrats, the period of the Legislative National Assembly is concerned with what the period of the Constituent Assembly was concerned with: the simple struggle between republicans and royalists. The movement itself, however, they sum up in the one shibboleth: "reaction" night, in which all cats are gray and which permits them to reel off their night watchman's commonplaces. And to be sure, at first sight the party of Order reveals a maze of different royalist factions which not only intrigue against each other - each seeking to elevate its own pretender to the throne and exclude the pretender of the opposing faction - but also all unite in common hatred of, and common onslaughts on, the "republic." In opposition to this royalist conspiracy the Montagne, for its part, appears as the representative of the "republic." The party of Order appears to be perpetually engaged in a "reaction," directed against press, association, and the like, neither more nor less than in Prussia, and, as in Prussia, carried out in the form of brutal police intervention by the bureaucracy, the gendarmerie, and the law courts. The Montagne, for its part, is just as continually occupied in warding off these attacks and thus defending the "eternal rights of man" as every so-called people's party has done, more or less, for a century and a half. If one 
looks at the situation and the parties more closely, however, this superficial appearance, which veils the class struggle and the peculiar physiognomy of this period, disappears.

Legitimists and Orleanists, as we have said, formed the two great factions of the party of Order. Was what held these factions fast to their pretenders and kept them apart from each other nothing but fleur-de-lis and tricolor, House of Bourbon and House of Orleans, different shades of royalism - was it at all the confession of faith of royalism? Under the Bourbons, big landed property had governed, with its priests and lackeys; under Orleans, high finance, large-scale industry, large-scale trade, that is, capital, with its retinue of lawyers, professors, and smoothtongued orators. The Legitimate Monarchy was merely the political expression of the hereditary rule of the lords of the soil, as the July Monarchy was only the political expression of the usurped rule of the bourgeois parvenus. What kept the two factions apart, therefore, was not any so-called principles, it was their material conditions of existence, two different kinds of property; it was the old contrast between town and country, the rivalry between capital and landed property. That at the same time old memories, personal enmities, fears and hopes, prejudices and illusions, sympathies and antipathies, convictions, articles of faith and principles bound them to one or the other royal house, who denies this? Upon the different forms of property, upon the social conditions of existence, rises an entire superstructure of distinct and peculiarly formed sentiments, illusions, modes of thought, and views of life. The entire class creates and forms them out of its material foundations and out of the corresponding social relations. The single individual, who derives them through tradition and upbringing, may imagine that they form the real motives and the starting point of his activity. While each faction, Orleanists and Legitimists, sought to make itself and the other believe that it was loyalty to the two royal houses which separated them, facts later proved that it was rather their divided interests which forbade the uniting of the two royal houses. And as in private life one differentiates between what a man thinks and says of himself and what he really is and does, so in historical struggles one must distinguish still more the phrases and fancies of parties from their real organism and their real interests, their conception of themselves from their reality. Orleanists and Legitimists found themselves side by side in the republic, with equal claims. If each side wished to effect the restoration of its own royal house against the other, that merely signified that each of the two great interests into which the bourgeoisie is split - landed property and capital - sought to restore its own supremacy and the subordination of the other. We speak of two interests of the bourgeoisie, for large landed property, despite its feudal coquetry and pride of race, has been rendered thoroughly bourgeois by the development of modern society. Thus the Tories in England long imagined that they were enthusiastic about monarchy, the church, and the beauties of the old English Constitution, until the day of danger wrung from them the confession that they are enthusiastic only about ground rent.

The royalists in coalition carried on their intrigues against one another in the press, in Ems, in Claremont, ${ }^{5}$ outside parliament. Behind the scenes they donned their old Orleanist and Legitimist liveries again and once more engaged in their old tourneys. But on the public stage, in their grand performances of state ${ }^{6}$ as a great parliamentary party, they put off their respective royal houses with mere obeisances and adjourn the restoration of the monarchy in infinitum. They do their real business as the party of Order, that is, under a social, not under a political title; as representatives of the bourgeois world order, not as knights of errant princesses; as the bourgeois class against other classes, not as royalists against the republicans. And as the party of Order they exercised more unrestricted and sterner domination over the other classes of society than ever previously under the Restoration or under the July Monarchy, a domination which, in general, was possible only under the form of the parliamentary republic, for only under this form could the two great divisions of the French bourgeoisie unite, and thus put the rule of their class instead of the regime of a privileged faction of it on the order of the day. If they nevertheless, as the party of Order, also insulted the republic and expressed their repugnance to it, this happened not merely from 
royalist memories. Instinct taught them that the republic, true enough, makes their political rule complete, but at the same time undermines its social foundation, since they must now confront the subjugated classes and contend against them without mediation, without the concealment afforded by the crown, without being able to divert the national interest by their subordinate struggles among themselves and with the monarchy. It was a feeling of weakness that caused them to recoil from the pure conditions of their own class rule and to yearn for the former more incomplete, more undeveloped, and precisely on that account less dangerous forms of this rule. On the other hand, every time the royalists in coalition come in conflict with the pretender who confronts them, with Bonaparte, every time they believe their parliamentary omnipotence endangered by the executive power - every time, therefore, that they must produce their political title to their rule - they come forward as republicans and not as royalists, from the Orleanist Thiers, who warns the National Assembly that the republic divides them least, to the Legitimist Berryer, who on December 2, 1851, as a tribune swathed in a tricolored sash, harangues the people assembled before the town hall of the Tenth Arrondissement in the name of the republic. To be sure, a mocking echo calls back to him: Henry V! Henry V!

As against the coalesced bourgeoisie, a coalition between petty bourgeois and workers had been formed, the so-called Social-Democratic party. The petty bourgeois saw that they were badly rewarded after the June days of 1848, that their material interests were imperiled, and that the democratic guarantees which were to insure the effectuation of these interests were called in question by the counterrevolution. Accordingly they came closer to the workers. On the other hand, their parliamentary representation, the Montagne, thrust aside during the dictatorship of the bourgeois republicans, had in the last half of the life of the Constituent Assembly reconquered its lost popularity through the struggle with Bonaparte and the royalist ministers. It had concluded an alliance with the socialist leaders. In February, 1849, banquets celebrated the reconciliation. A joint program was drafted, joint election committees were set up and joint candidates put forward. The revolutionary point was broken off and a democratic turn given to the social demands of the proletariat; the purely political form was stripped off the democratic claims of the petty bourgeoisie and their socialist point thrust forward. Thus arose social-democracy. The new Montagne, the result of this combination, contained, apart from some supernumeraries from the working class and some socialist sectarians, the same elements as the old Montagne, but numerically stronger. However, in the course of development it had changed with the class that it represented. The peculiar character of social-democracy is epitomized in the fact that democraticrepublican institutions are demanded as a means, not of doing away with two extremes, capital and wage labor, but of weakening their antagonism and transforming it into harmony. However different the means proposed for the attainment of this end may be, however much it may be trimmed with more or less revolutionary notions, the content remains the same. This content is the transformation of society in a democratic way, but a transformation within the bounds of the petty bourgeoisie. Only one must not get the narrow-minded notion that the petty bourgeoisie, on principle, wishes to enforce an egoistic class interest. Rather, it believes that the special conditions of its emancipation are the general conditions within whose frame alone modern society can be saved and the class struggle avoided. Just as little must one imagine that the democratic representatives are indeed all shopkeepers or enthusiastic champions of shopkeepers. According to their education and their individual position they may be as far apart as heaven and earth. What makes them representatives of the petty bourgeoisie is the fact that in their minds they do not get beyond the limits which the latter do not get beyond in life, that they are consequently driven, theoretically, to the same problems and solutions to which material interest and social position drive the latter practically. This is, in general, the relationship between the political and literary representatives of a class and the class they represent.

After this analysis it is obvious that if the Montagne continually contends with the party of Order for the republic and the so-called rights of man, neither the republic nor the rights of man are its 
final end, any more than an army which one wants to deprive of its weapons and which resists has taken the field in order to remain in possession of its own weapons.

Immediately, as soon as the National Assembly met, the party of Order provoked the Montagne. The bourgeoisie now felt the necessity of making an end of the democratic petty bourgeois, just as a year before it had realized the necessity of settling with the revolutionary proletariat. But the situation of the adversary was different. The strength of the proletarian party lay in the streets, that of the petty bourgeois in the National Assembly itself. It was therefore a question of decoying them out of the National Assembly into the streets and causing them to smash their parliamentary power themselves, before time and circumstances could consolidate it. The Montagne rushed headlong into the trap.

The bombardment of Rome by the French troops was the bait that was thrown. It violated Article 5 of the constitution, which forbids the French Republic to employ its military forces against the freedom of another people. ${ }^{7}$ In addition to this, Article 54 prohibited any declaration of war by the executive power without the assent of the National Assembly, and by its resolution of May 8 the Constituent Assembly had disapproved of the Roman expedition. On these grounds LedruRollin brought in a bill of impeachment against Bonaparte and his ministers on June 11, 1849. Exasperated by the wasp stings of Thiers, he actually let himself be carried away to the point of threatening that he would defend the constitution by every means, even with arms in hand. The Montagne rose to a man and repeated this call to arms. On June 12 the National Assembly rejected the bill of impeachment, and the Montagne left the parliament. The events of June 13 are known: the proclamation issued by a section of the Montagne declaring Bonaparte and his ministers "outside the constitution"; the street procession of the democratic National Guard, who, unarmed as they were, dispersed on encountering the troops of Changarnier, etc., etc. A part of the Montagne fled abroad; another part was arraigned before the High Court at Bourges; $;^{8}$ and a parliamentary regulation subjected the remainder to the schoolmasterly surveillance of the President of the National Assembly. Paris was again declared in a state of siege and the democratic part of its National Guard dissolved. Thus the influence of the Montagne in parliament and the power of the petty bourgeois in Paris were broken.

Lyon, where June 13 had given the signal for a bloody insurrection of the workers, ${ }^{9}$ was, along with the five surrounding departments, likewise declared in a state of siege, a condition that has continued up to the present moment.

The bulk of the Montagne had left its vanguard in the lurch, having refused to subscribe to its proclamation. The press had deserted, only two journals having dared to publish the pronunciamento. The petty bourgeois betrayed their representatives in that the National Guard either stayed away or, where they appeared, hindered the building of barricades. The representatives had duped the petty bourgeois in that the alleged allies from the army were nowhere to be seen. Finally, instead of gaining an accession of strength from it, the democratic party had infected the proletariat with its own weakness and, as usual with the great deeds of democrats, the leaders had the satisfaction of being able to charge their "people" with desertion, and the people the satisfaction of being able to charge its leaders with humbugging it.

Seldom had an action been announced with more noise than the impending campaign of the Montagne, seldom had an event been trumpeted with greater certainty or longer in advance than the inevitable victory of the democracy. Most assuredly the democrats believe in the trumpets before whose blasts the walls of Jericho fell down. And as often as they stand before the ramparts of despotism, they seek to imitate the miracle. If the Montagne wished to triumph in parliament it should not have called to arms. If it called to arms in parliament it should not have acted in parliamentary fashion in the streets. If the peaceful demonstration was meant seriously, then it was folly not to foresee that it would be given a warlike reception. If a real struggle was intended, then it was a queer idea to lay down the weapons with which it would have to be waged. But the revolutionary threats of the petty bourgeois and their democratic representatives are mere 
attempts to intimidate the antagonist. And when they have run into a blind alley, when they have sufficiently compromised themselves to make it necessary to activate their threats, then this is done in an ambiguous fashion that avoids nothing so much as the means to the end and tries to find excuses for succumbing. The blaring overture that announced the contest dies away in a pusillanimous snarl as soon as the struggle has to begin, the actors cease to take themselves $a u$ sorieux, and the action collapses completely, like a pricked bubble.

No party exaggerates its means more than the democratic, none deludes itself more lightmindedly over the situation. Since a section of the army had voted for it, the Montagne was now convinced that the army would revolt for it. And on what occasion? On an occasion which, from the standpoint of the troops, had no other meaning than that the revolutionists took the side of the Roman soldiers against the French soldiers. On the other hand, the recollections of June, 1848, were still too fresh to allow of anything but a profound aversion on the part of the proletariat toward the National Guard and a thoroughgoing mistrust of the democratic chiefs on the part of the chiefs of the secret societies. To iron out these differences, it was necessary for great common interests to be at stake. The violation of an abstract paragraph of the constitution could not provide these interests. Had not the constitution been repeatedly violated, according to the assurance of the democrats themselves? Had not the most popular journals branded it as counterrevolutionary botchwork? But the democrat, because he represents the petty bourgeoisie that is, a transition class, in which the interests of two classes are simultaneously mutually blunted - imagines himself elevated above class antagonism generally. The democrats concede that a privileged class confronts them, but they, along with all the rest of the nation, form the people. What they represent is the people's rights; what interests them is the people's interests. Accordingly, when a struggle is impending they do not need to examine the interests and positions of the different classes. They do not need to weigh their own resources too critically. They have merely to give the signal and the people, with all its inexhaustible resources, will fall upon the oppressors. Now if in the performance their interests prove to be uninteresting and their potency impotence, then either the fault lies with pernicious sophists, who split the indivisible people into different hostile camps, or the army was too brutalized and blinded to comprehend that the pure aims of democracy are the best thing for it, or the whole thing has been wrecked by a detail in its execution, or else an unforeseen accident has this time spoiled the game. In any case, the democrat comes out of the most disgraceful defeat just as immaculate as he was innocent when he went into it, with the newly won conviction that he is bound to win, not that he himself and his party have to give up the old standpoint, but, on the contrary, that conditions have to ripen to suit him.

Therefore one must not imagine the Montagne, decimated and broken though it was, and humiliated by the new parliamentary regulation, as being particularly miserable. If June 13 had removed its chiefs, it made room, on the other hand, for men of lesser caliber, whom this new position flattered. If their impotence in parliament could no longer be doubted, they were entitled now to confine their actions to outbursts of moral indignation and blustering declamation. If the party of Order affected to see embodied in them, as the last official representatives of the revolution, all the terrors of anarchy, they could in reality be all the more insipid and modest. They consoled themselves, however, for June 13 with the profound utterance: but if they dare to attack universal suffrage, well then - then we'll show them what we are made of! Nous verrons! [We shall see!]

So far as the Montagnards who fled abroad are concerned, it is sufficient to remark here that Ledru-Rollin, because in barely a fortnight he had succeeded in ruining irretrievably the powerful party at whose head he stood, now found himself called upon to form a French government in partibus; that to the extent that the level of the revolution sank and the official bigwigs of official France became more dwarf-like, his figure in the distance, removed from the scene of action, seemed to grow in stature; that he could figure as the republican pretender for 1852 , and that he 
issued periodical circulars to the Wallachians and other peoples in which the despots of the Continent were threatened with the deeds of himself and his confederates. Was Proudhon altogether wrong when he cried to these gentlemen: "Vous n'etes que des blagueurs" ["you are nothing but windbags"]?

On June 13 the party of Order had not only broken the Montagne, it had effected the subordination of the constitution to the majority decisions of the National Assembly. And it understood the republic thus: that the bourgeoisie rules here in parliamentary forms, without, as in a monarchy, encountering any barrier such as the veto power of the executive or the right to dissolve parliament. This was a parliamentary republic, as Thiers termed it. But whereas on June 13 the bourgeoisie secured its omnipotence within the house of parliament, did it not afflict parliament itself, as against the executive authority and the people, with incurable weakness by expelling its most popular part? By surrendering numerous deputies without further ado on the demand of the courts, it abolished its own parliamentary immunity. The humiliating regulations to which it subjected the Montagne exalted the President of the Republic in the same measure as it degraded the individual representatives of the people. By branding an insurrection for the protection of the constitutional charter an anarchic act aiming at the subversion of society, it precluded the possibility of its appealing to insurrection should the executive authority violate the constitution in relation to it. And by the irony of history, the general who on Bonaparte's instructions bombarded Rome and thus provided the immediate occasion for the constitutional revolt of June 13, that very Oudinot had to be the man offered by the party of Order imploringly and unfailingly to the people as general on behalf of the constitution against Bonaparte on December 2, 1851. Another hero of June 13, Vieyra, who was lauded from the tribune of the National Assembly for the brutalities he committed in the democratic newspaper offices at the head of a gang of National Guards belonging to high finance circles - this same Vieyra had been initiated into Bonaparte's conspiracy and he contributed substantially to depriving the National Assembly in the hour of its death of any protection by the National Guard.

June 13 had still another meaning. The Montagne had wanted to force the impeachment of Bonaparte. Its defeat was therefore a direct victory for Bonaparte, his personal triumph over his democratic enemies. The party of Order gained the victory; Bonaparte had only to cash in on it. He did so. On June 14 a proclamation could be read on the walls of Paris in which the President, reluctantly, against his will, compelled as it were by the sheer force of events, comes forth from his cloistered seclusion and, posing as misunderstood virtue, complains of the calumnies of his opponents and, while he seems to identify his person with the cause of order, rather identifies the cause of order with his person. Moreover, the National Assembly had, it is true, subsequently approved the expedition against Rome, but Bonaparte had taken the initiative in the matter. After having reinstalled the High Priest Samuel in the Vatican, he could hope to enter the Tuileries as King David ${ }^{10}$. He had won the priests over to his side.

The revolt of June 13 was confined, as we have seen, to a peaceful street procession. No war laurels were therefore to be won against it. Nevertheless, at a time as poor as this in heroes and events, the party of Order transformed this bloodless battle into a second Austerlitz. ${ }^{11}$ Platform and press praised the army as the power of order, in contrast to the popular masses representing the impotence of anarchy, and extolled Changarnier as the "bulwark of society," a deception in which he himself finally came to believe. Surreptitiously, however, the corps that seemed doubtful were transferred from Paris, the regiments which had shown the most democratic sentiments in the elections were banished from France to Algiers; the turbulent spirits among the troops were relegated to penal detachments; and finally the isolation of the press from the barracks and of the barracks from bourgeois society was systematically carried out.

Here we have reached the decisive turning point in the history of the French National Guard. In 1830 it was decisive in the overthrow of the Restoration. Under Louis Philippe every rebellion miscarried in which the National Guard stood on the side of the troops. When in the February 
days of 1848 it evinced a passive attitude toward the insurrection and an equivocal one toward Louis Philippe, he gave himself up for lost and actually was lost. Thus the conviction took root that the revolution could not be victorious without the National Guard, nor the army against it. This was the superstition of the army in regard to civilian omnipotence. The June days of 1848, when the entire National Guard, with the troops of the line, put down the insurrection, had strengthened the superstition. After Bonaparte's assumption of office, the position of the National Guard was to some extent weakened by the unconstitutional union, in the person of Changarnier, of the command of its forces with the command of the First Army Division.

Just as the command of the National Guard appeared here as an attribute of the military commander in chief, so the National Guard itself appeared as only an appendage of the troops of the line. Finally, on June 13 its power was broken, and not only by its partial disbandment, which from this time on was periodically repeated all over France, until mere fragments of it were left behind. The demonstration of June 13 was, above all, a demonstration of the democratic National Guards. They had not, to be sure, borne their arms, but had worn their uniforms against the army; precisely in this uniform, however, lay the talisman. The army convinced itself that this uniform was a piece of woolen cloth like any other. The spell was broken. In the June days of 1848, bourgeoisie and petty bourgeoisie had united as the National Guard with the army against the proletariat; on June 13,1849, the bourgeoisie let the petty-bourgeois National Guard be dispersed by the army; on December 2, 1851, the National Guard of the bourgeoisie itself had vanished, and Bonaparte merely registered this fact when he subsequently signed the decree for its disbandment, Thus the bourgeoisie had itself smashed its last weapon against the army; the moment the petty bourgeoisie no longer stood behind it as a vassal, but before it as a rebel, it had to smash it as in general it was bound to destroy all its means of defense against absolutism with its own hand as soon as it had itself become absolute.

Meanwhile, the party of Order celebrated the reconquest of a power that seemed lost in 1848 only to be found again, freed from its restraints, in 1849, celebrated by means of invectives against the republic and the constitution, of curses on all future, present, and past revolutions, including that which its own leaders had made, and in laws by which the press was muzzled, association destroyed, and the state of siege regulated as an organic institution. The National Assembly then adjourned from the middle of August to the middle of October, after having appointed a permanent commission for the period of its absence. During this recess the Legitimists intrigued with Ems, the Orleanists with Claremont, Bonaparte by means of princely tours, and the Departmental Councils in deliberations on a revision of the constitution: incidents which regularly recur in the periodic recesses of the National Assembly and which I propose to discuss only when they become events. Here it may merely be remarked, in addition, that it was impolitic for the National Assembly to disappear from the stage for considerable intervals and leave only a single, albeit a sorry, figure to be seen at the head of the republic, that of Louis Bonaparte, while to the scandal of the public the party of Order fell asunder into its royalist component parts and followed its conflicting desires for restoration. As often as the confused noise of parliament grew silent during these recesses and its body dissolved into the nation, it became unmistakably clear that only one thing was still lacking to complete the true form of this republic: to make the former's recess permanent and replace the latter's inscription, Liberté, Egalité, Fraternité, with the unambiguous words: infantry, cavalry, artillery!

\footnotetext{
${ }^{1}$ On April 16, 1848 a peaceful procession of Paris workers marched towards the Town Hall to present a petition to the Provisional Government for "organisation of labour" and "abolition of the exploitation of man by man." The workers encountered battalions of the bourgeois national guard and were forced to retreat.
} 
On May 15, 1848 Paris workers led by Blanqui, Barbès and others took revolutionary action against the anti-labour and anti-democratic policy of the bourgeois Constituent Assembly which had opened on May 4. The participants in the mass demonstration forced their way into the Assembly, demanded the formation of a Ministry of Labour and presented a number of other demands. An attempt was made to form a revolutionary government. National guards from the bourgeois quarters and regular troops succeeded, however, in restoring the power of the Constituent Assembly. The leaders of the movement were arrested and put on trial.

${ }^{2}$ The Fronde - a movement in France against the absolutist regime and its prop, the government of Cardinal Mazarin. It was active from 1648 to 1653 and invoked various social sections, which in marry cases pursued opposite aims, from radical peasant and plebeian elements and oppositional bourgeoisie, to high-ranking officials who sought to maintain their privileges, and aristocrats seeking lucrative posts, pensions and allowances. The defeat of the Fronde led to the strengthening of absolutism.

${ }^{3}$ Marx refers here to a Fairy Tale of Hans Christian Andersen, 'The Shadow', published in 1847, which was influenced by Chamisso's 'Peter Schlemihl'. There is a good treatment of the story on Wikipedia. In the Andersen story, the character has 'lost' his shadow, as in Marx's reference; in Chamisso's story, he has sold it to the devil.

${ }^{4}$ The ruling Bonapartist circles acid the counter-revolutionary the press, preparing coup d'état of December 2, 1851, did everything they could to scare all timid and law-abiding citizens by the prospect of anarchy, revolutionary plots, a new Jacquerie and encroachments on property, during the presidential election, scheduled for May 1852. A special roMle in this campaign was played by the pamphlet Le spectre rouge de 1852 (Brussels, 1851) by A. Romieu, a former prefect of police.

${ }^{5}$ Ems - a health resort in Germany where a Legitimist conference was held in August 1849; it was attended by the Count de Chambord, pretender to the French throne under the name of Henry V.

Claremont - a house near London, residence of Louis Philippe after his flight from France.

${ }^{6}$ Marx uses the term "Haupt- und Staatsaktionen" ("principal and spectacular actions"), which has several meanings. In the seventeenth and the first half of the eighteenth century, it denoted plays performed by, German touring companies. The plays, which were rather formless, presented tragic historical events in a bombastic and at the same time coarse and farcical way.

Secondly, this term can denote major political events. It was used in this sense by a trend in German historical science known as "objective historiography" Leopold Ranke was one of its chief representatives. He regarded Haupt- und Staatsaktionen as the main subject-matter of history.

7 The expeditionary corps under General Oudinot, sent to Italy by decision of President Louis Bonaparte and the French Government, was driven back from Rome by the troops of the Roman Republic on April 30,1849. But, in violation of the terms of the armistice signed by the French, Oudinot launched a new offensive on June 3. Throughout the siege of Rome until the fall of the Republic on July 3, 1849 the city was repeatedly subjected to heavy bombardment.

Article V belongs to the introductory part of the French Constitution of 1848: the articles of the main part of the Constitution are numbered in Arabic numerals.

${ }^{8}$ On August 10, 1849 the Legislative Assembly adopted a law under which "instigators and supporters of the conspiracy, and the attempt of June 13" were liable to trial by the High Court. Thirty-four deputies of the Montagne (Alexandre Ledru-Rollin, Felix Pyat and Victor Considerant among them) were deprived of their mandates and put on trial (those who had emigrated were tried by default).

On June 13 the editorial offices of democratic and socialist newspapers were raided and many of these papers were banned. 
${ }^{9}$ The events in Paris sparked off an armed uprising of Lyons workers and artisans on June 15, 1849. The insurgents occupied the Croix-Rousse district and erected barricades there, but were overcome by troops after several hours of stubborn fighting.

${ }^{10}$ An ironical allusion to the plans of Louis Napoleon, who expected to receive the French Crown from the hands of Pius IX, whose temporal power he helped restore. According to the Bible, David was anointed king by the prophet Samuel in opposition to the Hebrew king Saul (1 Samuel 16:13).

${ }^{11}$ The battle of Austerlitz between the Russo-Austrian and the French armies on December 2, 1805 ended in victory for the French commanded by Napoleon I. 


\section{IV}

In the middle of October, 1849, the National Assembly met once more. On November 1 Bonaparte surprised it with a message in which he announced the dismissal of the Barrot-Falloux Ministry and the formation of a new ministry. No one has ever sacked lackeys with less ceremony than Bonaparte his ministers. The kicks that were intended for the National Assembly were given in the meantime to Barrot \& Co.

The Barrot Ministry, as we have seen, had been composed of Legitimists and Orleanists; it was a ministry of the party of Order. Bonaparte had needed it to dissolve the republican Constituent Assembly, to bring about the expedition against Rome, and to break the Democratic party. Behind this ministry he had seemingly effaced himself, surrendered governmental power into the hands of the party of Order, and donned the modest character mask that the responsible editor of a newspaper wore under Louis Philippe, the mask of the homme de paille [straw man]. He now threw off a mask which was no longer the light veil behind which he could hide his physiognomy, but an iron mask which prevented him from displaying a physiognomy of his own. He had appointed the Barrot Ministry in order to blast the republican National Assembly in the name of the party of Order; he dismissed it in order to declare his own name independent of the National Assembly of the party of Order.

Plausible pretexts for this dismissal were not lacking. The Barrot Ministry neglected even the decencies that would have let the President of the Republic appear as a power side by side with the National Assembly. During the recess of the National Assembly Bonaparte published a letter to Edgar Ney in which he seemed to disapprove of the illiberal attitude of the Pope, just as in opposition to the Constituent Assembly he had published a letter in which he commended Oudinot for the attack on the Roman republic. When the National Assembly now voted the budget for the Roman expedition, Victor Hugo, out of alleged liberalism, brought up this letter for discussion. The party of Order with scornfully incredulous outcries stifled the idea that Bonaparte's ideas could have any political importance. Not one of the ministers took up the gauntlet for him. On another occasion Barrot, with his well-known hollow rhetoric, let fall from the platform words of indignation concerning the "abominable intrigues" that, according to his assertion, went on in the immediate entourage of the President. Finally, while the ministry obtained from the National Assembly a widow's pension for the Duchess of Orleans it rejected any proposal to increase the Civil List of the President. And in Bonaparte the imperial pretender was so intimately bound up with the adventurer down on his luck that the one great idea, that he was called to restore the empire, was always supplemented by the other, that it was the mission of the French people to pay his debts.

The Barrot-Falloux Ministry was the first and last parliamentary ministry that Bonaparte brought into being. Its dismissal forms, accordingly, a decisive turning point. With it the party of Order lost, never to reconquer it, an indispensable position for the maintenance of the parliamentary regime, the lever of executive power. It is immediately obvious that in a country like France, where the executive power commands an army of officials numbering more than half a million individuals and therefore constantly maintains an immense mass of interests and livelihoods in the most absolute dependence; where the state enmeshes, controls, regulates, superintends, and tutors civil society from its most comprehensive manifestations of life down to its most insignificant stirrings, from its most general modes of being to the private existence of individuals; where through the most extraordinary centralization this parasitic body acquires a ubiquity, an omniscience, a capacity for accelerated mobility, and an elasticity which finds a counterpart only in the helpless dependence, the loose shapelessness of the actual body politic it is obvious that in such a country the National Assembly forfeits all real influence when it loses

command of the ministerial posts, if it does not at the same time simplify the administration of the 
state, reduce the army of officials as far as possible, and, finally, let civil society and public opinion create organs of their own, independent of the governmental power. But it is precisely with the maintenance of that extensive state machine in its numerous ramifications that the material interests of the French bourgeoisie are interwoven in the closest fashion. Here it finds posts for its surplus population and makes up in the form of state salaries for what it cannot pocket in the form of profit, interest, rents, and honorariums. On the other hand, its political interests compelled it to increase daily the repressive measures and therefore the resources and the personnel of the state power, while at the same time it had to wage an uninterrupted war against public opinion and mistrustfully mutilate, cripple, the independent organs of the social movement, where it did not succeed in amputating them entirely. Thus the French bourgeoisie was compelled by its class position to annihilate, on the one hand, the vital conditions of all parliamentary power, and therefore, likewise, of its own, and to render irresistible, on the other hand, the executive power hostile to it.

The new ministry was called the Hautpoul Ministry. Not in the sense that General Hautpoul had received the rank of Prime Minister. Rather, simultaneously with Barrot's dismissal, Bonaparte abolished this dignity, which, true enough, condemned the President of the Republic to the status of the legal nonentity of a constitutional monarch, but of a constitutional monarch without throne or crown, without scepter or sword, without freedom from responsibility, without imprescriptible possession of the highest state dignity, and worst of all, without a Civil List. The Hautpoul Ministry contained only one man of parliamentary standing, the moneylender Fould, one of the most notorious of the high financiers. To his lot fell the Ministry of Finance. Look up the quotations on the Paris Bourse and you will find that from November 1, 1849, onward the French fonds [government securities] rise and fall with the rise and fall of Bonapartist stocks. While Bonaparte had thus found his ally in the Bourse, he at the same time took possession of the police by appointing Carlier police prefect of Paris.

Only in the course of development, however, could the consequences of the change of ministers come to light. To begin with, Bonaparte had taken a step forward only to be driven backward all the more conspicuously. His brusque message was followed by the most servile declaration of allegiance to the National Assembly. As often as the ministers dared to make a diffident attempt to introduce his personal fads as legislative proposals, they themselves seemed to carry out, against their will and compelled by their position, comical commissions whose fruitlessness they were persuaded of in advance. As often as Bonaparte blurted out his intentions behind the ministers' backs and played with his "idees napoleoniennes," ${ }^{1}$ his own ministers disavowed him from the tribune of the National Assembly. His usurpatory longings seemed to make themselves heard only in order that the malicious laughter of his opponents might not be muted. He behaved like an unrecognized genius, whom all the world takes for a simpleton. Never did he enjoy the contempt of all classes in fuller measure than during this period. Never did the bourgeoisie rule more absolutely, never did it display more ostentatiously the insignia of domination.

I need not write here the history of its legislative activity, which is summarized during this period in two laws: in the law reestablishing the wine tax and the education law abolishing unbelief. ${ }^{2}$ If wine drinking was made harder for the French, they were presented all the more plentifully with the water of true life. If in the law on the wine tax the bourgeoisie declared the old, hateful French tax system to be inviolable, it sought through the education law to insure among the masses the old state of mind that put up with the tax system. One is astonished to see the Orleanists, the liberal bourgeois, these old apostles of Voltaireanism and eclectic philosophy, entrust to their hereditary enemies, the Jesuits, the superintendence of the French mind. However Orleanists and Legitimists could part company in regard to the pretenders to the throne, they understood that securing their united rule necessitated the uniting of the means of repression of two epochs, that the means of subjugation of the July Monarchy had to be supplemented and strengthened by the means of subjugation of the Restoration. 
The peasants, disappointed in all their hopes, crushed more than ever by the low level of grain prices on the one hand, and by the growing burden of taxes and mortgage debts on the other, began to bestir themselves in the departments. They were answered by a drive against the schoolmasters, who were made subject to the clergy, by a drive against the mayors, made subject to the prefects, and by a system of espionage to which all were made subject. In Paris and the large towns reaction itself has the physiognomy of its epoch and challenges more than it strikes down. In the countryside it becomes dull, coarse, petty, tiresome, and vexatious, in a word, the gendarme. One comprehends how three years of the regime of the gendarme, consecrated by the regime of the priest, were bound to demoralize immature masses.

Whatever amount of passion and declamation might be employed by the party of Order against the minority from the tribune of the National Assembly, its speech remained as monosyllabic as that of the Christians, whose words were to be: Yea, yea; nay, nay! As monosyllabic on the platform as in the press. Flat as a riddle whose answer is known in advance. Whether it was a question of the right of petition or the tax on wine, freedom of the press or free trade, the clubs or the municipal charter, protection of personal liberty or regulation of the state budget, the watchword constantly recurs, the theme remains always the same, the verdict is ever ready and invariably reads: "Socialism!" Even bourgeois liberalism is declared socialistic, bourgeois enlightenment socialistic, bourgeois financial reform socialistic. It was socialistic to build a railway where a canal already existed, and it was socialistic to defend oneself with a cane when one was attacked with a rapier.

This was not merely a figure of speech, fashion, or party tactics. The bourgeoisie had a true insight into the fact that all the weapons it had forged against feudalism turned their points against itself, that all the means of education it had produced rebelled against its own civilization, that all the gods it had created had fallen away from it. It understood that all the so-called bourgeois liberties and organs of progress attacked and menaced its class rule at its social foundation and its political summit simultaneously, and had therefore become "socialistic." In this menace and this attack it rightly discerned the secret of socialism, whose import and tendency it judges more correctly than so-called socialism knows how to judge itself; the latter can, accordingly, not comprehend why the bourgeoisie callously hardens its heart against it, whether it sentimentally bewails the sufferings of mankind, or in Christian spirit prophesies the millennium and universal brotherly love, or in humanistic style twaddles about mind, education, and freedom, or in doctrinaire fashion invents a system for the conciliation and welfare of all classes. What the bourgeoisie did not grasp, however, was the logical conclusion that its own parliamentary regime, its political rule in general, was now also bound to meet with the general verdict of condemnation as being socialistic. As long as the rule of the bourgeois class had not been completely organized, as long as it had not acquired its pure political expression, the antagonism of the other classes likewise could not appear in its pure form, and where it did appear could not take the dangerous turn that transforms every struggle against the state power into a struggle against capital. If in every stirring of life in society it saw "tranquillity" imperiled, how could it want to maintain at the head of society a regime of unrest, its own regime, the parliamentary regime, this regime that, according to the expression of one of its spokesmen, lives in struggle and by struggle? The parliamentary regime lives by discussion, how shall it forbid discussion? Every interest, every social institution, is here transformed into general ideas, debated as ideas; how shall any interest, any institution, sustain itself above thought and impose itself as an article of faith? The struggle of the orators on the platform evokes the struggle of the scribblers of the press; the debating club in parliament is necessarily supplemented by debating clubs in the salons and the bistros; the representatives, who constantly appeal to public opinion, give public opinion the right to speak its real mind in petitions. The parliamentary regime leaves everything to the decision of majorities; how shall the great majorities outside parliament not want to decide? When you play the fiddle at the top of the state, what else is to be expected but that those down below dance? 
Thus by now stigmatizing as "socialistic" what it had previously extolled as "liberal," the bourgeoisie confesses that its own interests dictate that it should be delivered from the danger of its own rule; that to restore tranquillity in the country its bourgeois parliament must, first of all, be given its quietus; that to preserve its social power intact its political power must be broken; that the individual bourgeois can continue to exploit the other classes and to enjoy undisturbed property, family, religion, and order only on condition that their class be condemned along with the other classes to like political nullity; that in order to save its purse it must forfeit the crown, and the sword that is to safeguard it must at the same time be hung over its own head as a sword of Damocles.

In the domain of the interests of the general citizenry, the National Assembly showed itself so unproductive that, for example, the discussions on the Paris-Avignon railway, which began in the winter of 1850, were still not ripe for conclusion on December 2, 1851. Where it did not repress or pursue a reactionary course it was stricken with incurable barrenness.

While Bonaparte's ministry partly took the initiative in framing laws in the spirit of the party of Order, and partly even outdid that party's harshness in their execution and administration, he, on the other hand, sought by childishly silly proposals to win popularity, to bring out his opposition to the National Assembly, and to hint at a secret reserve that was only temporarily prevented by conditions from making its hidden treasures available to the French people. Such was the proposal to decree an increase in pay of four sous a day to the noncommissioned officers. Such was the proposal of an honor-system loan bank for the workers. Money as a gift and money as a loan, it was with prospects such as these that he hoped to lure the masses. Donations and loans the financial science of the lumpen proletariat, whether of high degree or low, is restricted to this. Such were the only springs Bonaparte knew how to set in action. Never has a pretender speculated more stupidly on the stupidity of the masses.

The National Assembly flared up repeatedly over these unmistakable attempts to gain popularity at its expense, over the growing danger that this adventurer, whom his debts spurred on and no established reputation held back, would venture a desperate coup. The discord between the party of Order and the President had taken on a threatening character when an unexpected event threw him back repentant into its arms. We mean the by-elections of March 10, 1850. These elections were held for the purpose of filling the representatives' seats that after June 13 had been rendered vacant by imprisonment or exile. Paris elected only social-democratic candidates. It even concentrated most of the votes on an insurgent of June, 1848, on De Flotte. Thus did the Parisian petty bourgeoisie, in alliance with the proletariat, revenge itself for its defeat on June 13, 1849. It seemed to have disappeared from the battlefield at the moment of danger only to reappear there on a more propitious occasion with more numerous fighting forces and with a bolder battle cry. One circumstance seemed to heighten the peril of this election victory. The army voted in Paris for the June insurgent against La Hitte, a minister of Bonaparte's, and in the departments largely for the Montagnards, who here too, though indeed not so decisively as in Paris, maintained the ascendancy over their adversaries.

Bonaparte saw himself suddenly confronted with revolution once more. As on January 29, 1849, as on June 13, 1849, so on March 10, 1850, he disappeared behind the party of Order. He made obeisance, he pusillanimously begged pardon, he offered to appoint any ministry it pleased at the behest of the parliamentary majority, he even implored the Orleanist and Legitimist party leaders, the Thiers, the Berryers, the Broglies, the Moles, in brief, the so-called burgraves, ${ }^{3}$ to take the helm of state themselves. The party of Order proved unable to take advantage of this opportunity that would never return. Instead of boldly possessing itself of the power offered, it did not even compel Bonaparte to reinstate the ministry dismissed on November 1; it contented itself with humiliating him by its forgiveness and adjoining M. Baroche to the Hautpoul Ministry. As public prosecutor this Baroche had stormed and raged before the High Court at Bourges, the first time against the revolutionists of May $15,{ }^{4}$ the second time against the democrats of June 13 , both 
times because of an attempt on the life of the National Assembly. None of Bonaparte's ministers subsequently contributed more to the degradation of the National Assembly, and after December 2, 1851, we meet him once more as the comfortably installed and highly paid vice president of the Senate. He had spat in the revolutionists' soup in order that Bonaparte might eat it up.

The social-democratic party, for its part, seemed only to look for pretexts to put its own victory once again in doubt and to blunt its point. Vidal, one of the newly elected representatives of Paris, had been elected simultaneously in Strasbourg. He was induced to decline the election for Paris and accept it for Strasbourg. And so, instead of making its victory at the polls conclusive and thereby compelling the party of Order to contest it in parliament at once, instead of thus forcing the adversary to fight at the moment of popular enthusiasm and favorable mood in the army, the democratic party wearied Paris during the months of March and April with a new election campaign, let the aroused popular passions wear themselves out in this repeated provisional election game, let the revolutionary energy satiate itself with constitutional successes, dissipate itself in petty intrigues, hollow declamations, and sham movements, let the bourgeoisie rally and make its preparations, and, lastly, weakened the significance of the March elections by a sentimental commentary in the April by-election, the election of Eugene Sue. In a word, it made an April Fool of March 10.

The parliamentary majority understood the weakness of its antagonist. Its seventeen burgraves for Bonaparte had left to it the direction of and responsibility for the attack - drew up a new electoral law, the introduction of which was entrusted to M. Faucher, who solicited this honor for himself. On May 8 he introduced the law by which universal suffrage was to be abolished, a residence of three years in the locality of the election to be imposed as a condition on the electors, and finally, the proof of this residence made dependent in the case of workers on a certificate from their employers.

Just as the democrats had, in revolutionary fashion, raged and agitated during the constitutional election contest, so now, when it was requisite to prove the serious nature of that victory arms in hand, did they in constitutional fashion preach order, calme majestueux, lawful action, that is to say, blind subjection to the will of the counterrevolution, which imposed itself as the law. During the debate the "Mountain" put the party of Order to shame by asserting, against the latter's revolutionary passion, the dispassionate attitude of the philistine who keeps within the law, and by felling that party to earth with the fearful reproach that it was proceeding in a revolutionary manner. Even the newly elected deputies were at pains to prove by their decorous and discreet action what a misconception it was to decry them as anarchists and construe their election as a victory for revolution. On May 31 the new electoral law went through. The Montagne contented itself with smuggling a protest into the President's pocket. The electoral law was followed by a new press law, by which the revolutionary newspaper press was entirely suppressed. ${ }^{5}$ It had deserved its fate. The National and La Presse, two bourgeois organs, were left after this deluge as the most advanced outposts of the revolution.

We have seen how during March and April the democratic leaders had done everything to embroil the people of Paris in a sham fight, how after May 8 they did everything to restrain them from a real fight. In addition to this, we must not forget that the year 1850 was one of the most splendid years of industrial and commercial prosperity, and the Paris proletariat was therefore fully employed. But the election law of May 31, 1850, excluded it from any participation in political power. It cut the proletariat off from the very arena of the struggle. It threw the workers back into the position of pariahs which they had occupied before the February Revolution. By letting themselves be led by the democrats in the face of such an event and forgetting the revolutionary interests of their class for momentary case and comfort, they renounced the honor of being a conquering power, surrendered to their fate, proved that the defeat of June, 1848, had put them out of the fight for years and that the historical process would for the present again have to go on over their heads. As for the petty-bourgeois democracy, which on June 13 had cried, 
"But if once universal suffrage is attacked, then we'll show them," it now consoled itself with the contention that the counterrevolutionary blow which had struck it was no blow and the law of May 31 no law. On the second Sunday in May, 1852, every Frenchman would appear at the polling place with ballot in one hand and sword in the other. With this prophecy it rested content. Lastly, the army was disciplined by its superior officers for the elections of March and April, 1850, just as it had been disciplined for those of May 28, 1849. This time, however, it said decidedly: "The revolution shall not dupe us a third time."

The law of May 31, 1850, was the coup d'etat of the bourgeoisie. All its conquests over the revolution hitherto had only a provisional character and were endangered as soon as the existing National Assembly retired from the stage. They depended on the hazards of a new general election, and the history of elections since 1848 irrefutably proved that the bourgeoisie's moral sway over the mass of the people was lost in the same measure as its actual domination developed. On March 10 universal suffrage declared itself directly against the domination of the bourgeoisie; the bourgeoisie answered by outlawing universal suffrage. The law of May 31 was therefore one of the necessities of the class struggle. On the other hand, the constitution required a minimum of two million votes to make an election of the President of the Republic valid. If none of the candidates for the presidency received this minimum, the National Assembly was to choose the President from among the three candidates to whom the largest number of votes would fall. At the time when the Constituent Assembly made this law, ten million electors were registered on the rolls of voters. In its view, therefore, a fifth of the people entitled to vote was sufficient to make the presidential election valid. The law of May 31 struck at least three million votes off the electoral rolls, reduced the number of people entitled to vote to seven million, and nevertheless retained the legal minimum of two million for the presidential election. It therefore raised the legal minimum from a fifth to nearly a third of the effective votes; that is, it did everything to smuggle the election of the President out of the hands of the people and into the hands of the National Assembly. Thus through the electoral law of May 31 the party of Order seemed to have made its rule doubly secure, by surrendering the election of the National Assembly and that of the President of the Republic to the stationary section of society.

\footnotetext{
${ }^{1}$ An ironical allusion to Louis Bonaparte's book Des Idées apoleoniennes. which he wrote in England and published in Paris and Brussels in 1839.

${ }^{2}$ The wine tax, abolished as of January 1, 1850 by decision of the Constituent Assembly, was reintroduced by a law of the Legislative Assembly on December 1 20-21, 1849.

The education law, which virtually placed the schools under the control of the clergy, was adopted by the Legislative Assembly on March 15-27, 1850. For an assessment of these laws see Karl Marx, The Class Struggles in France, 1848 to 1850.

${ }^{3}$ The reference is to the commission of 17 Orleanists and Legitimists- deputies of the Legislative Assembly- appointed by the Minister of the Interior on May 1, 1850 to draft a new electoral law. Its members were nicknamed burgraves, a name borrowed from the title of a historical drama by Victor Hugo, as an allusion to their unwarranted claims to power and their reactionary aspirations. The drama is set in medieval Germany, where the Burggraf was governor, appointed by the emperor, of a Burg (city) or district.

${ }^{4}$ From March 7 to April 3, 1849 the leaders of the Paris workers' uprising of May 15, 1848 were tried at Bourges on a charge of conspiring against the government. Barbés and Albert were sentenced to exile, Blanqui to ten years solitary confinement and the rest of the accused to various terms of imprisonment or exile.
}

On April 16, 1848 a peaceful procession of Paris workers marched towards the Town Hall to present a petition to the Provisional Government for "organisation of labour" and "abolition of the exploitation 
of man by man." The workers encountered battalions of the bourgeois national guard and were forced to retreat.

On May 15, 1848 Paris workers led by Blanqui, Barbès and others took revolutionary action against the anti-labour and anti-democratic policy of the bourgeois Constituent Assembly which had opened on May 4. The participants in the mass demonstration forced their way into the Assembly, demanded the formation of a Ministry of Labour and presented a number of other demands. An attempt was made to form a revolutionary government. National guards from the bourgeois quarters and regular troops succeeded, however, in restoring the power of the Constituent Assembly. The leaders of the movement were arrested and put on trial.

${ }^{5}$ The press law passed by the Legislative Assembly in July 1850 ("Loi sur le cautionnement des journaux et le timbre des écrits périodiques et non périodiques. 16-23 juillet 1850") considerably increased the caution money which newspaper publishers had to deposit, and introduced a stamp-duty, which applied also to pamphlets. This new law was a continuation of reactionary measures which virtually led to the abolition of freedom of the press in France (see also Karl Marx, The Class Struggles in France, 1848 to 1850). 


\section{V}

As soon as the revolutionary crisis had been weathered and universal suffrage abolished, the struggle between the National Assembly and Bonaparte broke out again.

The constitution had fixed Bonaparte's salary at 600,000 francs. Barely six months after his installation he succeeded in increasing this sum to twice as much, for Odilon Barrot wrung from the Constituent National Assembly an extra allowance of 600,000 francs a year for so-called representation moneys. After June 13 Bonaparte had caused similar requests to be voiced, this time without eliciting response from Barrot. Now, after May 31, he at once availed himself of the favorable moment and had his ministers propose a Civil List of three millions in the National Assembly. A long life of adventurous vagabondage had endowed him with the most developed antennae for feeling out the weak moments when he might squeeze money from his bourgeois. He practiced chantage [blackmail] regularly. The National Assembly had violated the sovereignty of the people with his assistance and his cognizance. He threatened to denounce its crime to the tribunal of the people unless it loosened its purse strings and purchased his silence with three million a year. It had robbed three million Frenchmen of their franchise. He demanded, for every Frenchman out of circulation, a franc in circulation, precisely three million francs. He, the elect of six millions, claimed damages for the votes which he said he had retrospectively been cheated out of. The Commission of the National Assembly refused the importunate man. The Bonapartist press threatened. Could the National Assembly break with the President of the Republic at a moment when in principle it had definitely broken with the mass of the nation? It rejected the annual Civil List, it is true, but it granted, for this once, an extra allowance of 2,160,000 francs. It thus rendered itself guilty of the double weakness of granting the money and of showing at the same time by its vexation that it granted it unwillingly. We shall see later for what purpose Bonaparte needed the money. After this vexatious aftermath, which followed on the heels of the abolition of universal suffrage and in which Bonaparte exchanged his humble attitude during the crisis of March and April for challenging impudence to the usurpatory parliament, the National Assembly adjourned for three months, from August 11 to November 11. In its place it left behind a Permanent Commission of twenty-eight members, which contained no Bonapartists but did contain some moderate republicans. The Permanent Commission of 1849 had included only Order men and Bonapartists. But at that time the party of Order declared itself permanently against the revolution. This time the parliamentary republic declared itself permanently against the President. After the law of May 31, this was the only rival that still confronted the party of Order.

When the National Assembly met once more in November, 1850, it seemed that, instead of the petty skirmishes it had hitherto had with the President, a great and ruthless struggle, a life-anddeath struggle between the two powers, had become inevitable.

As in 1849 so during this year's parliamentary recess - the party of Order had broken up into its separate factions, each occupied with its own restoration intrigues, which had obtained fresh nutriment through the death of Louis Philippe. The Legitimist king, Henry V, had even nominated a formal ministry which resided in Paris and in which members of the Permanent Commission held seats. Bonaparte, in his turn, was therefore entitled to make tours of the French departments, and according to the disposition of the town he favored with his presence, now more or less covertly, now more or less overtly, to divulge his own restoration plans and canvass votes for himself. On these processions, which the great official Moniteur and the little private Moniteurs of Bonaparte naturally had to celebrate as triumphal processions, he was constantly accompanied by persons affiliated with the Society of December 10. This society dates from the year 1849. On the pretext of founding a benevolent society, the lumpen proletariat of Paris had been organized into secret sections, each section led by Bonapartist agents, with a Bonapartist 
general at the head of the whole. Alongside decayed roués with dubious means of subsistence and of dubious origin, alongside ruined and adventurous offshoots of the bourgeoisie, were vagabonds, discharged soldiers, discharged jailbirds, escaped galley slaves, swindlers, mountebanks, lazzaroni, ${ }^{1}$ pickpockets, tricksters, gamblers, maquereaux [pimps], brothel keepers, porters, literati, organ grinders, ragpickers, knife grinders, tinkers, beggars — in short, the whole indefinite, disintegrated mass, thrown hither and thither, which the French call la bohème; from this kindred element Bonaparte formed the core of the Society of December 10. A "benevolent society" - insofar as, like Bonaparte, all its members felt the need of benefiting themselves at the expense of the laboring nation. This Bonaparte, who constitutes himself chief of the lumpenproletariat, who here alone rediscovers in mass form the interests which he personally pursues, who recognizes in this scum, offal, refuse of all classes the only class upon which he can base himself unconditionally, is the real Bonaparte, the Bonaparte sans phrase. An old, crafty roué, he conceives the historical life of the nations and their performances of state as comedy in the most vulgar sense, as a masquerade in which the grand costumes, words, and postures merely serve to mask the pettiest knavery. Thus his expedition to Strasbourg, where the trained Swiss vulture played the part of the Napoleonic eagle. For his irruption into Boulogne he puts some London lackeys into French uniforms. They represent the army. ${ }^{2}$ In his Society of December 10 he assembles ten thousand rascals who are to play the part of the people as Nick Bottom [A character in Shakespeare's Midsummer Night's Dream. - Ed.] that of the lion. At a moment when the bourgeoisie itself played the most complete comedy, but in the most serious manner in the world, without infringing any of the pedantic conditions of French dramatic etiquette, and was itself half deceived, half convinced of the solemnity of its own performance of state, the adventurer, who took the comedy as plain comedy, was bound to win. Only when he has eliminated his solemn opponent, when he himself now takes his imperial role seriously and under the Napoleonic mask imagines he is the real Napoleon, does he become the victim of his own conception of the world, the serious buffoon who no longer takes world history for a comedy but his comedy for world history. What the national ateliers ${ }^{3}$ were for the socialist workers, what the Gardes mobile were for the bourgeois republicans, the Society of December 10 was for Bonaparte, the party fighting force peculiar to him. On his journeys the detachments of this society packing the railways had to improvise a public for him, stage popular enthusiasm, roar Vive l'Empereur, insult and thrash republicans, under police protection, of course. On his return journeys to Paris they had to form the advance guard, forestall counter-demonstrations or disperse them. The Society of December 10 belonged to him, it was his work, his very own idea. Whatever else he appropriates is put into his hands by the force of circumstances; whatever else he does, the circumstances do for him or he is content to copy from the deeds of others. But Bonaparte with official phrases about order, religion, family, and property in public, before the citizens, and with the secret society of the Schufterles and Spiegelbergs ${ }^{4}$, the society of disorder, prostitution, and theft, behind him - that is Bonaparte himself as the original author, and the history of the Society of December 10 is his own history.

Now it had happened by way of exception that people's representatives belonging to the party of Order came under the cudgels of the Decembrists. Still more. Yon, the police commissioner assigned to the National Assembly and charged with watching over its safety, acting on the deposition of a certain Allais, advised the Permanent Commission that a section of the Decembrists had decided to assassinate General Changarnier and Dupin, the President of the National Assembly, and had already designated the individuals who were to perpetrate the deed. One comprehends the terror of M. Dupin. A parliamentary inquiry into the Society of December 10 - that is, the profanation of the Bonapartist secret world - seemed inevitable. Just before the meeting of the National Assembly Bonaparte providently disbanded his society, naturally only on paper, for in a detailed memoir at the end of 1851 Police Prefect Carlier still sought in vain to move him to really break up the Decembrists. 
The Society of December 10 was to remain the private army of Bonaparte until he succeeded in transforming the public army into a Society of December 10. Bonaparte made the first attempt at this shortly after the adjournment of the National Assembly, and precisely with the money just wrested from it. As a fatalist, he lives in the conviction that there are certain higher powers which man, and the soldier in particular, cannot withstand. Among these powers he counts, first and foremost, cigars and champagne, cold poultry and garlic sausage. Accordingly, to begin with, he treats officers and non-commissioned officers in his Elysée apartments to cigars and champagne, cold poultry and garlic sausage. On October 3 he repeats this maneuver with the mass of the troops at the St. Maur review, and on October 10 the same maneuver on a still larger scale at the Satory army parade. The uncle remembered the campaigns of Alexander in Asia, the nephew the triumphal marches of Bacchus in the same land. Alexander was a demigod, to be sure, but Bacchus was a god and moreover the tutelary deity of the Society of December 10.

After the review of October 3, the Permanent Commission summoned War Minister Hautpoul. He promised that these breaches of discipline would not recur. We know how on October 10 Bonaparte kept Hautpoul's word. As commander in chief of the Paris army, Changarnier had commanded at both reviews. At once a member of the Permanent Commission, chief of the National Guard, the "savior" of January 29 and June 13, the "bulwark of society," the candidate of the party of Order for presidential honors, the suspected monk of two monarchies, he had hitherto never acknowledged himself as the subordinate of the War Minister, had always openly derided the republican constitution, and had pursued Bonaparte with an ambiguous lordly protection. Now he was consumed with zeal for discipline against the War Minister and for the constitution against Bonaparte. While on October 10 a section of the cavalry raised the shout: "Vive Napoléon! Vivent les saucissons!" [Hurrah for Napoléon! Hurrah for the sausages!] Changarnier arranged that at least the infantry marching past under the command of his friend Neumayer should preserve an icy silence. As a punishment, the War Minister relieved General Neumayer of his post in Paris at Bonaparte's instigation, on the pretext of appointing him commanding general of the Fourteenth and Fifteenth divisions. Neumayer refused this exchange of posts and so had to resign. Changarnier, for his part, published an order of the day on November 2 in which he forbade the troops to indulge in political outcries or demonstrations of any kind while under arms. The Elysee newspapers attacked Changarnier; the papers of the party of Order attacked Bonaparte; the Permanent Commission held repeated secret sessions in which it was repeatedly proposed to declare the country in danger; the army seemed divided into two hostile camps, with two hostile general staffs, one in the Elysée, where Bonaparte resided, the other in the Tuileries, the quarters of Changarnier. It seemed that only the meeting of the National Assembly was needed to give the signal for battle. The French public judged this friction between Bonaparte and Changarnier like the English journalist who characterized it in these words:

"The political housemaids of France are sweeping away the glowing lava of the revolution with old brooms and wrangle with one another while they do their work."

Meanwhile, Bonaparte hastened to remove the War Minister Hautpoul, to pack him off in all haste to Algiers, and to appoint General Schramm War Minister in his place. On November 12 he sent to the National Assembly a message of American prolixity, overloaded with detail, redolent of order, desirous of reconciliation, constitutionally acquiescent, treating of all and sundry, but not of the questions brûlantes [burning questions] of the moment. As if in passing, he made the remark that according to the express provisions of the constitution the President alone could dispose of the army. The message closed with the following words of great solemnity:

"Above all things, France demands tranquillity... But bound by an oath, I shall keep within the narrow limits that it has set for me.... As far as I am concerned, elected by the people and owing my power to it alone, I shall always bow to its lawfully expressed will. Should you resolve at this session on a revision of the 
constitution, a Constituent Assembly will regulate the position of the executive power. If not, then the people will solemnly pronounce its decision in 1852. But whatever the solutions of the future may be, let us come to an understanding, so that passion, surprise, or violence may never decide the destiny of a great nation.... What occupies my attention, above all, is not who will rule France in 1852, but how to employ the time which remains at my disposal so that the intervening period may pass by without agitation or disturbance. I have opened my heart to you with sincerity; you will answer my frankness with your trust, my good endeavors with your cooperation, and God will do the rest."

The respectable, hypocritically moderate, virtuously commonplace language of the bourgeoisie reveals its deepest meaning in the mouth of the autocrat of the Society of December 10 and the picnic hero of St. Maur and Satory.

The burgraves of the party of Order did not delude themselves for a moment concerning the trust that this opening of the heart deserved. About oaths they had long been blasé they numbered in their midst veterans and virtuosos of political perjury. Nor had they failed to hear the passage about the army. They observed with annoyance that in its discursive enumeration of lately enacted laws the message passed over the most important law, the electoral law, in studied silence, and moreover, in the event of there being no revision of the constitution, left the election of the President in 1852 to the people. The electoral law was the lead ball chained to the feet of the party of Order, which prevented it from walking and so much the more from storming forward! Moreover, by the official disbandment of the Society of December 10 and the dismissal of War Minister Hautpoul, Bonaparte had with his own hand sacrificed the scapegoats on the altar of the country. He had blunted the edge of the expected collision. Finally, the party of Order itself anxiously sought to avoid, to mitigate, to gloss over any decisive conflict with the executive power. For fear of losing their conquests over the revolution, they allowed their rival to carry off the fruits thereof. "Above all things, France demands tranquillity." This was what the party of Order had cried to the revolution since February [1848], this was what Bonaparte's message cried to the party of Order. "Above all things, France demands tranquillity." Bonaparte committed acts that aimed at usurpation, but the party of Order committed "unrest" if it raised a row about these acts and construed them hypochondriacally. The sausages of Satory were quiet as mice when no one spoke of them. "Above all things, France demands tranquillity." Bonaparte demanded, therefore, that he be left in peace to do as he liked and the parliamentary party was paralyzed by a double fear, the fear of again evoking revolutionary unrest and the fear of itself appearing as the instigator of unrest in the eyes of its own class, in the eyes of the bourgeoisie. Consequently, since France demanded tranquillity above all things, the party of Order dared not answer "war" after Bonaparte had talked "peace" in his message. The public, which had anticipated scenes of great scandal at the opening of the National Assembly, was cheated of its expectations. The opposition deputies, who demanded the submission of the Permanent Commission's minutes on the October events, were out-voted by the majority. On principle, all debates that might cause excitement were eschewed. The proceedings of the National Assembly during November and December, 1850, were without interest.

At last, toward the end of December, guerrilla warfare began over a number of prerogatives of parliament. The movement got bogged down in petty squabbles about the prerogatives of the two powers, since the bourgeoisie had done away with the class struggle for the moment by abolishing universal suffrage.

A judgment for debt had been obtained from the court against Mauguin, one of the people's representatives. In answer to the inquiry of the president of the court, the Minister of Justice, Rouher, declared that a capias should be issued against the debtor without further ado. Mauguin was thus thrown into debtors' prison. The National Assembly flared up when it learned of the assault. Not only did it order his immediate release, but it even had him fetched forcibly from 
Clichy the same evening, by its clerk. In order, however, to confirm its faith in the sanctity of private property and with the idea at the back of its mind of opening, in case of need, a place of safekeeping for Montagnards who had become troublesome, it declared imprisonment of people's representatives for debt permissible when its consent had been previously obtained. It forgot to decree that the President might also be locked up for debt. It destroyed the last semblance of the immunity that enveloped the members of its own body.

It will be remembered that, acting on the information given by a certain Allais, Police Commissioner Yon had denounced a section of the Decembrists for planning the murders of Dupin and Changarnier. In reference to this, at the very first session the quaestors made the proposal that parliament should form a police force of its own, paid out of the private budget of the National Assembly and absolutely independent of the police prefect. The Minister of the Interior, Baroche, protested against this invasion of his domain. A miserable compromise on this matter was concluded, according to which, true, the police commissioner of the Assembly was to be paid out of its private budget and to be appointed and dismissed by its quaestors, but only after previous agreement with the Minister of the Interior. Meanwhile the government had started criminal proceedings against Alais, and here it was easy to represent his information as a hoax and through the mouth of the public prosecutor to cast ridicule upon Dupin, Changarnier, Yon, and the whole National Assembly. Thereupon, on December 29, Minister Baroche writes a letter to Dupin in which he demands Yon's dismissal. The bureau of the Assembly, alarmed by its violence in the Mauguin affair and accustomed when it has ventured a blow at the executive power to receive two blows from it in return, does not sanction this decision. It dismisses Yon as a reward for his official zeal and robs itself of a parliamentary prerogative indispensable against a man who does not decide by night in order to execute by day, but decides by day and executes by night.

We have seen how on great and striking occasions during the months of November and December the National Assembly avoided or quashed the struggle with the executive power. Now we see it compelled to take up the struggle on the pettiest occasions. In the Mauguin affair it confirms the principle of imprisoning people's representatives for debt, but reserves the right to have it applied only to representatives obnoxious to itself and wrangles over this infamous privilege with the Minister of Justice. Instead of availing itself of the alleged murder plot to decree an inquiry into the Society of December 10 and irredeemably unmasking Bonaparte before France and Europe in his true character of chief of the Paris lumpen proletariat, it lets the conflict be degraded to a point where the only issue between it and the Minister of the Interior is which of them has the authority to appoint and dismiss a police commissioner. Thus during the whole of this period we see the party of Order compelled by its equivocal position to dissipate and disintegrate its struggle with the executive power in petty jurisdictional squabbles, pettifoggery, legalistic hairsplitting, and delimitational disputes, and to make the most ridiculous matters of form the substance of its activity. It does not dare take up the conflict at the moment when this has significance from the standpoint of principle, when the executive power has really exposed itself and the cause of the National Assembly would be the cause of the nation. By so doing it would give the nation its marching orders, and it fears nothing more than that the nation should move. On such occasions it accordingly rejects the motions of the Montagne and proceeds to the order of the day. The question at issue in its large aspects having thus been dropped, the executive power calmly waits for the time when it can again take up the same question on petty and insignificant occasions, when this is, so to speak, of only local parliamentary interest. Then the repressed rage of the party of Order breaks out, then it tears the curtain away from the coulisses, then it denounces the President, then it declares the republic in danger, but then, also, its fervor appears absurd and the occasion for the struggle seems a hypocritical pretext or altogether not worth fighting about. The parliamentary storm becomes a storm in a teacup, the fight becomes an intrigue, the conflict a scandal. While the revolutionary classes gloat with malicious joy over the 
humiliation of the National Assembly, for they are just as enthusiastic about the parliamentary prerogatives of this Assembly as the latter is about the public liberties, the bourgeoisie outside parliament does not understand how the bourgeoisie inside parliament can waste time over such petty squabbles and imperil tranquillity by such pitiful rivalries with the President. It becomes confused by a strategy that makes peace at the moment when all the world is expecting battles, and attacks at the moment when all the world believes peace has been made.

On December 20 Pascal Duprat interpellated the Minister of the Interior concerning the Gold Bars Lottery. This lottery was a "daughter of Elysium." Bonaparte with his faithful followers had brought her into the world and Police Prefect Carlier had placed her under his official protection, although French law forbids all lotteries except raffles for charitable purposes. Seven million lottery tickets at a franc-a-piece, the profits ostensibly to be devoted to shipping Parisian vagabonds to California. On the one hand, golden dreams were to supplant the socialist dreams of the Paris proletariat, the seductive prospect of the first prize the doctrinaire right to work. Naturally the Paris workers did not recognize in the glitter of the California gold bars the inconspicuous francs that were enticed out of their pockets. In the main, however, the matter was nothing short of a downright swindle. The vagabonds who wanted to open California gold mines without troubling to leave Paris were Bonaparte himself and his debt-ridden Round Table. The three millions voted by the National Assembly had been squandered in riotous living; in one way or another coffers had to be replenished. In vain had Bonaparte opened a national subscription for the building of so-called cites ouvrieres [workers' cities], and headed the list himself with a considerable sum. The hard-hearted bourgeois waited mistrustfully for him to pay up his share, and since this naturally did not ensue, the speculation in socialist castles in the air immediately fell to the ground. The gold bars proved a better draw. Bonaparte \& Co. were not content to pocket part of the excess of the seven millions over the bars to be allotted in prizes; they manufactured false lottery tickets; they issued ten, fifteen, and even twenty tickets with the same number - a financial operation in the spirit of the Society of December 10! Here the National Assembly was confronted not with the fictitious President of the Republic but with Bonaparte in the flesh. Here it could catch him in the act, in conflict not with the constitution but with the Code penal. If after Duprat's interpellation it proceeded to the order of the day, this did not happen merely because Girardin's motion that it should declare itself "satisfied" reminded the party of Order of its own systematic corruption. The bourgeois, and above all the bourgeois inflated into a statesman, supplements his practical meanness by theoretical extravagance. As a statesman he becomes, like the state power that confronts him, a higher being that can be fought only in a higher, consecrated fashion.

Bonaparte, who precisely because he was a bohemian, a princely lumpen proletarian, had the advantage over a rascally bourgeois in that he could conduct the struggle meanly, now saw, after the Assembly guided him with its own hand across the slippery ground of the military banquets, the reviews, the Society of December 10, and finally the Code penal, that the moment had come when he could pass from an apparent defensive to the offensive. The minor defeats meanwhile sustained by the Minister of Justice, the Minister of War, the Minister of the Navy, and the Minister of Finance, through which the National Assembly signified its snarling displeasure, troubled him little. He not only prevented the ministers from resigning and thus recognizing the sovereignty of parliament over the executive power, but could now consummate what he had begun during the recess of the National Assembly: the severance of the military power from parliament, the removal of Changarnier.

An Elysée paper published an order of the day alleged to have been addressed during the month of May to the First Army Division, and therefore proceeding from Changarnier, in which the officers were urged, in the event of an insurrection, to give no quarter to the traitors in their own ranks, but to shoot them immediately, and to refuse troops to the National Assembly if it should requisition them. On January 3, 1851, the cabinet was interpellated concerning this order of the 
day. For the investigation of this matter it requests a breathing space, first of three months, then of a week, finally of only twenty-four hours. The Assembly insists on an immediate explanation. Changarnier rises and declares that there never was such an order of the day. He adds that he will always hasten to comply with the demands of the National Assembly and that in case of a clash it can count on him. It receives his declaration with indescribable applause and passes a vote of confidence in him. It abdicates, it decrees its own impotence and the omnipotence of the army by placing itself under the private protection of a general; but the general deceives himself when he puts at its command against Bonaparte a power that he holds only as a fief from the same Bonaparte, and when, in his turn, he expects to be protected by this parliament, his own protègé in need of protection. Changarnier, however, believes in the mysterious power with which the bourgeoisie has endowed him since January 29, 1849. He considers himself the third power, existing side by side with both the other state powers. He shares the fate of the rest of this epoch's heroes, or rather saints, whose greatness consists precisely in the biased great opinion of them that their party creates in its own interests and who shrink to everyday figures as soon as circumstances call on them to perform miracles. Unbelief is, in general, the mortal enemy of these reputed heroes who are really saints. Hence their majestically moral indignation at the dearth of enthusiasm displayed by wits and scoffers.

That same evening the ministers were summoned to the Elysée. Bonaparte insists on the dismissal of Changarnier; five ministers refuse to sign; the Moniteur announces a ministerial crisis, and the press of the party of Order threatens to form a parliamentary army under Changarnier's command. The party of Order had constitutional authority to take this step. It merely had to appoint Changarnier president of the National Assembly and requisition any number of troops it pleased for its protection. It could do so all the more safely as Changarnier still actually stood at the head of the army and the Paris National Guard and was only waiting to be requisitioned together with the army. The Bonapartist press did not as yet even dare to question the right of the National Assembly to requisition troops directly, a legal scruple that in the given circumstances did not look promising. That the army would have obeyed the order of the National Assembly is probable when one bears in mind that Bonaparte had to search all Paris for eight days in order, finally, to find two generals - Baraguay d'Hilliers and Saint-Jean d'Angely - who declared themselves ready to countersign Changarnier's dismissal. That the party of Order, however, would have found in its own ranks and in parliament the necessary number of votes for such a resolution is more than doubtful, when one considers that eight days later two hundred and eighty-six votes detached themselves from the party and that in December, 1851, at the last hour of decision, the Montagne still rejected a similar proposal. Nevertheless, the burgraves might, perhaps, still have succeeded in spurring the mass of their party to a heroism that consisted in feeling themselves secure behind a forest of bayonets and accepting the services of an army that had deserted to their camp. Instead of this, on the evening of January 6, Messrs. the Burgraves betook themselves to the Elysée to make Bonaparte desist from dismissing Changarnier by using statesmanlike phrases and urging considerations of state. Whomever one seeks to persuade, one acknowledges as master of the situation. On January 12, Bonaparte, assured by this step, appoints a new ministry in which the leaders of the old ministry, Fould and Baroche, remain. Saint-Jean D'Angely becomes War Minister, the Moniteur publishes the decree dismissing Changarnier, and his command is divided between Baraguay d'Hilliers, who receives the First Army Division, and Perrot, who receives the National Guard. The bulwark of society has been discharged, and while this does not cause any tiles to fall from the roofs, quotations on the Bourse are, on the other hand, going up.

By repulsing the army, which places itself in the person of Changarnier at its disposal, and so surrendering the army irrevocably to the President, the party of Order declares that the bourgeoisie has forfeited its vocation to rule. A parliamentary ministry no longer existed. Having now indeed lost its grip on the army and the National Guard, what forcible means remained to it 
with which simultaneously to maintain the usurped authority of parliament over the people and its constitutional authority against the President? None. Only the appeal to impotent principles remained to it now, to principles that it had itself always interpreted merely as general rules, which one prescribes for others in order to be able to move all the more freely oneself. The dismissal of Changarnier and the falling of the military power into Bonaparte's hands closes the first part of the period we are considering, the period of struggle between the party of Order and the executive power. War between the two powers has now been openly declared, is openly waged, but only after the party of Order has lost both arms and soldiers. Without the ministry, without the army, without the people, without public opinion, after its electoral law of May 31 no longer the representative of the sovereign nation, sans eyes, sans ears, sans teeth, sans everything, the National Assembly had undergone a gradual transformation into an ancient French parliament $^{5}$ that has to leave action to the government and content itself with growling remonstrances post festum [belatedly].

The party of Order receives the new ministry with a storm of indignation. General Bedeau recalls to mind the mildness of the Permanent Commission during the recess, and the excessive consideration it showed by waiving the publication of its minutes. The Minister of the Interior himself now insists on the publication of these minutes, which by this time have naturally become as dull as ditch water, disclose no fresh facts, and have not the slightest effect on the blasé public. Upon Remusat's proposal the National Assembly retires into its office and appoints a "Committee for Extraordinary Measures." Paris departs the less from the rut of its everyday routine because at this moment trade is prosperous, factories are busy, corn prices low, foodstuffs overflowing, and the savings banks receiving fresh deposits daily. The "extraordinary measures" that parliament has announced with so much noise fizzle out on January 18 in a no-confidence vote against the ministry without General Changarnier ever being mentioned. The party of Order was forced to frame its motion in this way to secure the votes of the republicans, since of all the ministry's measures, Changarnier's dismissal was precisely the only one the republicans approved of, while the party of Order was in fact not in a position to Censure the other ministerial acts, which it had itself dictated.

The no-confidence vote of January 18 was passed by four hundred and fifteen votes to two hundred and eighty-six. Thus, it was carried only by a coalition of the extreme Legitimists and Orleanists with the pure republicans and the Montagne. Thus it proved that the party of Order had lost in conflicts with Bonaparte not only the ministry, not only the army, but also its independent parliamentary majority; that a squad of representatives had deserted its camp, out of fanaticism for conciliation, out of fear of the struggle, out of lassitude, out of family regard for the state salaries so near and dear to them, out of speculation about ministerial posts becoming vacant (Odilon Barrot), out of sheer egoism, which makes the ordinary bourgeois always inclined to sacrifice the general interest of his class for this or that private motive. From the first, the Bonapartist representatives adhered to the party of Order only in the struggle against revolution. The leader of the Catholic party, Montalembert, had already at that time thrown his influence into the Bonapartist scale, since he despaired of the parliamentary party's prospects of life. Lastly, the leaders of this party, Thiers and Berryer, the Orleanist and the Legitimist, were compelled openly to proclaim themselves republicans, to confess that their hearts were royalist but their heads republican, that the parliamentary republic was the sole possible form for the rule of the bourgeoisie as a whole. Thus they were compelled, before the eyes of the bourgeois class itself, to stigmatize the restoration plans, which they continued indefatigably to pursue behind parliament's back, as an intrigue as dangerous as it was brainless.

The no-confidence vote of January 18 hit the ministers and not the President. But it was not the ministry, it was the President who had dismissed Changarnier. Should the party of Order impeach Bonaparte himself? Because of his restoration desires? The latter merely supplemented their own. Because of his conspiracy in connection with the military reviews and the Society of December 
10? They had buried these themes long since under routine orders of the day. Because of the dismissal of the hero of January 29 and June 13, the man who in May, 1850, threatened to set fire to all four corners of Paris in the event of a rising? Their allies of the Montagne and Cavaignac did not even allow them to raise the fallen bulwark of society by means of an official attestation of sympathy. They themselves could not deny the President the constitutional authority to dismiss a general. They only raged because he made an unparliamentary use of his constitutional right. Had they not continually made an unconstitutional use of their parliamentary prerogative, particularly in regard to the abolition of universal suffrage? They were therefore reduced to moving within strictly parliamentary limits. And it took that peculiar malady which since 1848 has raged all over the Continent, parliamentary cretinism, which holds those infected by it fast in an imaginary world and robs them of all sense, all memory, all understanding of the rude external world - it took this parliamentary cretinism for those who had destroyed all the conditions of parliamentary power with their own hands, and were bound to destroy them in their struggle with the other classes, still to regard their parliamentary victories as victories and to believe they hit the President by striking at his ministers. They merely gave him the opportunity to humiliate the National Assembly afresh in the eyes of the nation. On January 20 the Moniteur announced that the resignation of the entire ministry had been accepted. On the pretext that no parliamentary party any longer had a majority - as the vote of January 18, this fruit of the coalition between Montagne and royalists, proved - and pending the formation of a new ministry, of which not one member was an Assembly representative, all being absolutely unknown and insignificant individuals; a ministry of mere clerks and copyists. The party of Order could now work to exhaustion playing with these marionettes; the executive power no longer thought it worth while to be seriously represented in the National Assembly. The more his ministers were pure dummies, the more obviously Bonaparte concentrated the whole executive power in his own person and the more scope he had to exploit it for his own ends.

In coalition with the Montagne, the party of Order revenged itself by rejecting the grant to the President of 1,800,000 francs which the chief of the Society of December 10 had compelled his ministerial clerks to propose. This time a majority of only a hundred and two votes decided the matter; thus twenty-seven fresh votes had fallen away since January 18; the dissolution of the party of Order was progressing. At the same time, so there might not for a moment be any mistake about the meaning of its coalition with the Montagne, it scorned even to consider a proposal signed by a hundred and eighty-nine members of the Montagne calling for a general amnesty of political offenders. It sufficed for the Minister of the Interior, a certain Vaisse, to declare that the tranquillity was only apparent, that in secret great agitation prevailed, that in secret ubiquitous societies were being organized, the democratic papers were preparing to come out again, the reports from the departments were unfavorable, the Geneva refugees were directing a conspiracy spreading by way of Lyon all over the South of France, France was on the verge of an industrial and commercial crisis, the manufacturers of Roubaix had reduced working hours, the prisoners of Belle Isle ${ }^{6}$ were in revolt - it sufficed for even a mere Vaisse to conjure up the red specter and the party of Order rejected without discussion a motion that would certainly have won the National Assembly immense popularity and thrown Bonaparte back into its arms. Instead of letting itself be intimidated by the executive power with the prospect of fresh disturbances, it ought rather to have allowed the class struggle a little elbow room, so as to keep the executive power dependent on it. But it did not feel equal to the task of playing with fire.

Meanwhile the so-called transition ministry continued to vegetate until the middle of April. Bonaparte wearied and befooled the National Assembly with continual new ministerial combinations. Now he seemed to want to form a republican ministry with Lamartine and Billault, now a parliamentary one with the inevitable Odilon Barrot, whose name is never missing when a dupe is necessary, then a Legitimist ministry with Vatimesnil and Benoit d'Azy, and then again an Orleanist one with Maleville. While he thus kept the different factions of the party of Order in 
tension against one another, and alarmed them as a whole by the prospect of a republican ministry and the consequent inevitable restoration of universal suffrage, he at the same time engendered in the bourgeoisie the conviction that his honest efforts to form a parliamentary ministry were being frustrated by the irreconcilability of the royalist factions. The bourgeoisie, however, cried out all the louder for a "strong government"; it found it all the more unpardonable to leave France "without administration," the more a general commercial crisis seemed now to be approaching, and won recruits for socialism in the towns just as the ruinously low price of corn did in the countryside. Trade daily became slacker, the number of unemployed increased perceptibly; ten thousand workers, at least, were breadless in Paris, innumerable factories stood idle in Rouen, Mulhouse, Lyon, Roubaix, Tourcoing, St. Ettienne, Elbeuf, etc. Under these circumstances Bonaparte could venture, on April 11, to restore the ministry of January 18: Messrs. Rouher, Fould, Baroche, etc., reinforced by M. Leon Faucher, whom the Constituent Assembly during its last days had, with the exception of five votes cast by ministers, unanimously stigmatized by a vote of no confidence for sending out false telegrams. The National Assembly had therefore gained a victory over the ministry on January 18, had struggled with Bonaparte for three months, only to have Fould and Baroche on April 11 admit the puritan Faucher as a third party into their ministerial alliance.

In November, 1849, Bonaparte had contented himself with an unparliamentary ministry, in January, 1851, with an extra-parliamentary one, and on April 11 he felt strong enough to form an anti-parliamentary ministry, which harmoniously combined in itself the no-confidence votes of both Assemblies, the Constituent and the Legislative, the republican and the royalist. This gradation of ministries was the thermometer with which parliament could measure the decrease of its own vital heat. By the end of April the latter had fallen so low that Persigny, in a personal interview, could urge Changarnier to go over to the camp of the President. Bonaparte, he assured him, regarded the influence of the National Assembly as completely destroyed, and the proclamation was already prepared that was to be published after the coup d'etat, which was kept steadily in view but was by chance again postponed. Changarnier informed the leaders of the party of Order of the obituary notice, but who believes that bedbug bites are fatal? And parliament, stricken, disintegrated, and death-tainted as it was, could not prevail upon itself to see in its duel with the grotesque chief of the Society of December 10 anything but a duel with a bedbug. But Bonaparte answered the party of Order as Agesilaus did King Agis: "I seem to thee an ant, but one day I shall be a lion." 7

\footnotetext{
${ }^{1}$ Lazzaroni - a contemptuous name for declassed proletarians, primarily in the Kingdom of Naples. These people were repeatedly used by reactionary governments against liberal and democratic movements.

${ }^{2}$ This refers to Louis Bonaparte's attempts during the July monarchy to stage a coup d'état by means of a military mutiny. On October 30, 1836 he succeeded, with the help of several Bonapartist officers, in inciting two artillery regiments of the Strasbourg garrison to mutiny, but they were disarmed within a few hours. Louis Bonaparte was arrested and deported to America. On August 6, 1840, taking advantage of a partial revival of Bonapartist sentiments in France, he landed in Boulogne with a handful of conspirators and attempted to raise a mutiny among the troops of the local garrison. This attempt likewise proved a failure. He was sentenced to life imprisonment, but escaped to England in 1846.

${ }^{3}$ The national ateliers (workshops) were instituted by the Provisional Government immediately after the February revolution of 1848. By this means the Government sought to discredit Louis Blanc's ideas on "the organisation of labour" in the eyes of the workers and, at the same time, to utilise those employed in the national workshops, organised on military lines, against the revolutionary proletariat. Revolutionary ideas, however, continued to gain ground in the national workshops. The Government
} 
took steps to reduce the number of workers employed in them, to send a large number off to public works in the provinces and finally to liquidate the workshops. This precipitated a proletarian uprising in Paris in June 1848. After its suppression, the Cavaignac Government issued a decree on July 3, disbanding the national workshops.

For an assessment of the national workshops see Karl Marx, The Class Struggles in France, 1848 to 1850.

${ }^{4}$ Schufterle and Spiegelberg are characters in Friedrich Schiller's play 'The Robbers'.

${ }^{5}$ The parliaments in France-judicial institutions that came into being in the Middle Ages. The Paris parliament was the highest court of appeal and also performed important administrative and political functions, such as the registration of royal decrees, without which they had no legal force. The parliaments enjoyed the right to remonstrate against government decrees. In the seventeenth and eighteenth centuries they consisted of officials of high birth called the "nobility of the mantle." The parliaments ultimately became the bulwark of Right-wing opposition to absolutism and impeded the implementation of even moderate reforms, and were abolished during the French Revolution. in 1790.

${ }^{6}$ Belle Isle - an island in the Bay of Biscay, a place of detention of political prisoners in 1849-57; among others, workers who took part in the Paris uprising in June 1848 were detained there.

${ }^{7}$ Here Marx is drawing a parallel with a story told by the Greek writer Athenaeus (2nd-3rd cent. A.D.) in his book Deipnosophistae (Dinner-Table Philosophers). The Egyptian Pharaoh Tachos, alluding to the small stature of the Spartan King Agesilaus, who had come with his troops to the Pharaoh's help, said: "The mountain was in labour. Zeus was afraid. But the mountain has brought forth a mouse." Agesilaus replied: "I seem to you now only a mouse, but the time will come when I will appear to you like a lion." 


\section{VI}

The coalition with the Montagne and the pure republicans, to which the party of Order saw itself condemned in its unavailing efforts to maintain possession of the military power and to reconquer supreme control of the executive power, proved incontrovertibly that it had forfeited its independent parliamentary majority. On May 28 the mere power of the calendar, of the hour hand of the clock, gave the signal for its complete disintegration. With May 28, the last year of the life of the National Assembly began. It now had to decide for continuing the constitution unaltered or for revising it. But revision of the constitution - that implied not only rule of the bourgeoisie or of the petty-bourgeois democracy, democracy or proletarian anarchy, parliamentary republic or Bonaparte, it implied at the same time Orleans or Bourbon! Thus fell in the midst of parliament the apple of discord that was bound to inflame openly the conflict of interests which split the party of Order into hostile factions. The party of Order was a combination of heterogeneous social substances. The question of revision generated a political temperature at which the product again decomposed into its original components.

The Bonapartists' interest in a revision was simple. For them it was above all a question of abolishing Article 45, which forbade Bonaparte's reelection and the prolongation of his authority. No less simple appeared the position of the republicans. They unconditionally rejected any revision; they saw in it a universal conspiracy against the republic. Since they commanded more than a quarter of the votes in the National Assembly, and according to the constitution threequarters of the votes were required for a resolution for revision to be legally valid and for the convocation of a revising Assembly, they needed only to count their votes to be sure of victory. And they were sure of victory.

As against these clear positions, the party of Order found itself inextricably caught in contradictions. If it should reject revision, it would imperil the status quo, since it would leave Bonaparte only one way out, that of force; and since on the second Sunday in May, 1852, at the decisive moment, it would be surrendering France to revolutionary anarchy, with a President who had lost his authority, with a parliament which for a long time had not possessed it, and with a people that meant to reconquer it. If it voted for constitutional revision, it knew that it voted in vain and would be bound to fail constitutionally because of the republicans' veto. If it unconstitutionally declared a simple majority vote to be binding, it could hope to dominate the revolution only if it subordinated itself unconditionally to the sovereignty of the executive power; then it would make Bonaparte master of the constitution, of its revision, and of the party itself. A partial revision, which would prolong the authority of the President, would pave the way for imperial usurpation. A general revision, which would shorten the existence of the republic, would bring the dynastic claims into unavoidable conflict, for the conditions of a Bourbon and an Orleanist restoration were not only different, they were mutually exclusive.

The parliamentary republic was more than the neutral territory on which the two factions of the French bourgeoisie, Legitimists and Orleanists, large landed property and industry, could dwell side by side with equality of rights. It was the unavoidable condition of their common rule, the sole form of state in which their general class interest subjected to itself at the same time both the claims of their particular factions and all the remaining classes of society. As royalists they fell back into their old antagonism, into the struggle for the supremacy of landed property or of money, and the highest expression of this antagonism, its personification, was their kings themselves, their dynasties. Hence the resistance of the party of Order to the recall of the Bourbons.

The Orleanist and people's representative Creton had in 1849, 1850, and 1851 periodically introduced a motion for the revocation of the decree exiling the royal families. Just as regularly, parliament presented the spectacle of an Assembly of royalists that obdurately barred the gates 
through which their exiled kings might return home. Richard III murdered Henry VI, remarking that he was too good for this world and belonged in heaven. The royalists declared France too bad to possess her kings again. Constrained by force of circumstances, they had become republicans and repeatedly sanctioned the popular decision that banished their kings from France.

A revision of the constitution - and circumstances compelled taking that into consideration called in question, along with the republic, the common rule of the two bourgeois factions, and revived, with the possibility of a monarchy, the rivalry of the interests which the monarchy had predominantly represented by turns, the struggle for the supremacy of one faction over the other. The diplomats of the party of Order believed they could settle the struggle by an amalgamation of the two dynasties, by a so-called fusion of the royalist parties and their royal houses. The real fusion of the Restoration and the July Monarchy was the parliamentary republic, in which Orleanist and Legitimist colors were obliterated and the various species of bourgeois disappeared into the bourgeois as such, the bourgeois genus. Now, however, Orleanist was to become Legitimist and Legitimist Orleanist. Royalty, in which their antagonism was personified, was to embody their unity, the expression of their exclusive factional interests was to become the expression of their common class interest, the monarchy was to do what only the abolition of two monarchies, the republic, could do and had done. This was the philosopher's stone, to produce which the doctors of the party of Order racked their brains. As if the Legitimist monarchy could ever become the monarchy of the industrial bourgeois or the bourgeois monarchy ever become the monarchy of the hereditary landed aristocracy. As if landed property and industry could fraternize under one crown, when the crown could descend to only one head, the head of the elder brother or of the younger. As if industry could come to terms with landed property at all, so long as landed property itself does not decide to become industrial. If Henry V should die tomorrow, the Count of Paris would not on that account become the king of the Legitimists unless he ceased to be the king of the Orleanists. The philosophers of fusion, however, who became more vociferous in proportion as the question of revision came to the fore, who had provided themselves with an official daily organ in the Assemblee Nationale, and who are again at work even at this very moment (February, 1852), considered the whole difficulty to be due to the opposition and rivalry of the two dynasties. The attempts to reconcile the Orleans family with Henry V, begun since the death of Louis Philippe, but, like the dynastic intrigues generally, played at only while the National Assembly was in recess, during the entr'actes, behind the scenes - sentimental coquetry with the old superstition rather than seriously meant business now became grand performances of state, enacted by the party of Order on the public stage, instead of in amateur theatricals as before. The couriers sped from Paris to Venice, from Venice to Claremont, ${ }^{1}$ from Claremont to Paris. The Count of Chambord issues a manifesto in which "with the help of all the members of his family" he announces not his, but the "national" restoration. The Orleanist Salvandy throws himself at the feet of Henry V. The Legitimist chiefs, Berryer, Benoit d'Azy, Saint-Priest, travel to Claremont to persuade the Orleans set, but in vain. The fusionists perceive too late that the interests of the two bourgeois factions neither lose exclusiveness nor gain pliancy when they become accentuated in the form of family interests, the interests of two royal houses. If Henry V were to recognize the Count of Paris as his heir - the sole success that the fusion could achieve at best - the House of Orleans would not win any claim that the childlessness of Henry $\mathrm{V}$ had not already secured to it, but it would lose all the claims it had gained through the July Revolution. It would waive its original claims, all the titles it had wrested from the older branch of the Bourbons in almost a hundred years of struggle; it would barter away its historical prerogative, the prerogative of the modem kingdom, for the prerogative of its genealogical tree. The fusion, therefore, would be nothing but a voluntary abdication of the House of Orleans, its resignation to Legitimacy, repentant withdrawal from the Protestant state church into the Catholic. A withdrawal, moreover, that would not even bring it to the throne it had lost, but to the steps of the throne where it had been born. The old Orleanist 
ministers, Guizot, Duchatel, etc., who likewise hastened to Claremont to advocate the fusion, in fact represented merely the Katzenjammer over the July Revolution, the despair about the bourgeois kingdom and the kingliness of the bourgeois, the superstitious belief in Legitimacy as the last charm against anarchy. Imagining themselves mediators between Orleans and Bourbons, they were in reality merely Orleanist renegades, and the Prince of Joinville received them as such. On the other hand, the viable, bellicose section of the Orleanists, Thiers, Baze, etc., convinced Louis Philippe's family all the more easily that if any directly monarchist restoration presupposed the fusion of the two dynasties, and if any such fusion presupposed abdication of the House of Orleans, it was, on the contrary, wholly in accord with the tradition of their forefathers to recognize the republic for the moment and wait until events permitted the conversion of the presidential chair into a throne. Rumors of Joinville's candidature were circulated, public curiosity was kept in suspense, and a few months later, in September, after the rejection of revision, his candidature was publicly proclaimed.

The attempt at a royalist fusion of Orleanists with Legitimists had thus not only failed; it had destroyed their parliamentary fusion, their common republican form, and had broken up the party of Order into its original component parts; but the more the estrangement between Claremont and Venice grew, the more their settlement collapsed and the Joinville agitation gained ground, so much the more eager and earnest became the negotiations between Bonaparte's minister Faucher and the Legitimists.

The disintegration of the party of Order did not stop at its original elements. Each of the two great factions, in its turn, decomposed all over again. It was as if all the old shadings that had formerly fought and jostled one another within each of the two circles, whether Legitimist or Orleanist, had thawed out again like dry Infusoria on contact with water, as if they had acquired anew sufficient vital energy to form groups of their own and independent antagonisms. The Legitimists dreamed they were back among the controversies between the Tuileries and the Pavillon Marsan, between Villèle and Polignac. ${ }^{2}$ The Orleanists relived the golden days of the tourney between Guizot, Mole, Broglie, Thiers, and Odilon Barrot.

The section of the party of Order that was eager for revision, but was divided again on the limits to revisions - a section composed of the Legitimists led by Berryer and Falloux, on the one hand, and by La Rochejaquelein, on the other, and of the conflict-weary Orleanists led by Mole, Broglie, Montalembert and Odilon Barrot - agreed with the Bonapartist representatives on the following indefinite and broadly framed motion: "With the object of restoring to the nation the full exercise of its sovereignty, the undersigned representatives move that the constitution be revised."

At the same time, however, they unanimously declared through their reporter Tocqueville that the National Assembly had no right to move the abolition of the republic, that this right was vested solely in the Revising Chamber. For the rest, the constitution might be revised only in a "legal" manner, hence only if the constitutionally prescribed three-quarters of the number of votes were cast in favor of revision. On July 19, after six days of stormy debate, revision was rejected, as was to be anticipated. Four hundred and forty-six votes were cast for it, but two hundred and seventyeight against. The extreme Orleanists, Thiers, Changarnier, etc., voted with the republicans and the Montagne.

Thus the majority of parliament declared against the constitution, but this constitution itself declared for the minority and that its vote was binding. But had not the party of Order subordinated the constitution to the parliamentary majority on May 31,1850 , and on June 13, 1849 ? Up to now, was not its whole policy based on the subordination of the paragraphs of the constitution to the decisions of the parliamentary majority? Had it not left to the democrats the antediluvian superstitious belief in the letter of the law, and castigated the democrats for it? At the present moment, however, revision of the constitution meant nothing but continuation of the presidential authority, just as continuation of the constitution meant nothing but Bonaparte's 
deposition. Parliament had declared for him, but the constitution declared against parliament. He therefore acted in the sense of parliament when he tore up the constitution and acted in the sense of the constitution when he adjourned parliament.

Parliament had declared the constitution and, with the latter, its own rule to be "beyond the majority"; by its vote it had abolished the constitution and prolonged the term of presidential power, while declaring at the same time that neither could the one die nor the other live so long as the Assembly itself continued to exist. Those who were to bury it were standing at the door. While it debated on revision, Bonaparte removed General Baraguay d'Hilliers, who had proved irresolute, from the command of the First Army Division and appointed in his place General Magnan, the victor of Lyons, ${ }^{3}$ the hero of the December days, one of his creatures, who under Louis Philippe had already more or less compromised himself in Bonaparte's favor on the occasion of the Boulogne expedition.

The party of Order proved by its decision on revision that it knew neither how to rule nor how to serve; neither how to live nor how to die; neither how to suffer the republic nor how to overthrow it; neither how to uphold the constitution nor how to throw it overboard; neither how to cooperate with the President nor how to break with him. To whom, then, did it look for the solution of all the contradictions? To the calendar, to the course of events. It ceased to presume to sway them. It therefore challenged events to assume sway over it, and thereby challenged the power to which, in the struggle against the people, it had surrendered one attribute after another until it stood impotent before this power. In order that the head of the executive power might be able the more undisturbedly to draw up his plan of campaign against it, strengthen his means of attack, select his tools, and fortify his positions, it resolved precisely at this critical moment to retire from the stage and adjourn for three months, from August 10 to November 4.

The parliamentary party was not only dissolved into its two great factions, each of these factions was not only split up within itself, but the party of Order in parliament had fallen out with the party of Order outside parliament. The spokesmen and scribes of the bourgeoisie, its platform and its press - in short, the ideologists of the bourgeoisie and the bourgeoisie itself, the representatives and the represented - faced one another in estrangement and no longer understood one another.

The Legitimists in the provinces, with their limited horizon and unlimited enthusiasm, accused their parliamentary leaders, Berryer and Falloux, of deserting to the Bonapartist camp and of defection from Henry V. Their fleur-de-lis minds believed in the fall of man, but not in diplomacy.

Far more fateful and decisive was the breach of the commercial bourgeoisie with its politicians. It reproached them not as the Legitimists reproached theirs, with having abandoned their principles, but on the contrary, with clinging to principles that had become useless.

I have indicated above that since Fould's entry into the ministry the section of the commercial bourgeoisie which had held the lion's share of power under Louis Philippe, namely, the aristocracy of finance, had become Bonapartist. Fould not only represented Bonaparte's interests in the Bourse, he represented at the same time the interests of the Bourse before Bonaparte. The position of the aristocracy of finance is most strikingly depicted in a passage from its European organ, the London Economist. In the issue of February 1, 1851, its Paris correspondent writes:

"Now we have it stated from numerous quarters that above all things France demands tranquillity. The President declares it in his message to the Legislative Assembly; it is echoed from the tribune; it is asserted in the journals; it is announced from the pulpit, it is demonstrated by the sensitiveness of the public funds at the least prospect of disturbance, and their firmness the instant it is made manifest that the executive is victorious."

In its issue of November 29, 1851, the Economist declares in its own name: 
"The President is the guardian of order, and is now recognized as such on every stock exchange of Europe."

The aristocracy of finance, therefore, condemned the parliamentary struggle of the party of Order with the executive power as a disturbance of order, and celebrated every victory of the President over its ostensible representatives as a victory of order. By the aristocracy of finance must here be understood not merely the great loan promoters and speculators in public funds, in regard to whom it is immediately obvious that their interests coincide with the interests of the state power. All modern finance, the whole of the banking business, is interwoven in the closest fashion with public credit. A part of their business capital is necessarily invested and put out at interest in quickly convertible public funds. Their deposits, the capital placed at their disposal and distributed by them among merchants and industrialists, are partly derived from the dividends of holders of government securities. If in every epoch the stability of the state power signified Moses and the prophets to the entire money market and to the priests of this money market, why not all the more so today, when every deluge threatens to sweep away the old states, and the old state debts with them?

The industrial bourgeoisie too, in its fanaticism for order, was angered by the squabbles of the parliamentary party of Order with the executive power. After their vote of January 18 on the occasion of Changarnier's dismissal, Thiers, Angles, Sainte-Beuve, etc., received from their constituents, in precisely the industrial districts, public reproofs in which their coalition with the Montagne was especially scourged as high treason to order. If, as we have seen, the boastful taunts, the petty intrigues which marked the struggle of the party of Order with the President merited no better reception, then on the other hand this bourgeois party, which required its representatives to allow the military power to pass from its own parliament to an adventurous pretender without offering resistance, was not even worth the intrigues that were squandered in its interests. It proved that the struggle to maintain its public interests, its own class interests, its political power, only troubled and upset it, as it disturbed private business.

With barely an exception the bourgeois dignitaries of the departmental towns, the municipal authorities, the judges of the commercial courts, etc., everywhere received Bonaparte on his tours in the most servile manner, even when, as in Dijon, he made an unrestrained attack on the National Assembly, and especially on the party of Order.

When trade was good, as it still was at the beginning of 1851, the commercial bourgeoisie raged against any parliamentary struggle, lest trade be put out of humor. When trade was bad, as it continually was from the end of February, 1851, the commercial bourgeoisie accused the parliamentary struggles of being the cause of stagnation and cried out for them to stop so that trade could start again. The revision debates came on just in this bad period. Since the question here was whether the existing form of state was to be or not to be, the bourgeoisie felt all the more justified in demanding from its representatives the ending of this torturous provisional arrangement and at the same time the maintenance of the status quo. There was no contradiction in this. By the end of the provisional arrangement it understood precisely its continuation, the postponement to a distant future of the moment when a decision had to be reached. The status quo could be maintained in only two ways: prolongation of Bonaparte's authority or his constitutional retirement and the election of Cavaignac. A section of the bourgeoisie desired the latter solution and knew no better advice to give its representatives than to keep silent and leave the burning question untouched. They were of the opinion that if their representatives did not speak, Bonaparte would not act. They wanted an ostrich parliament that would hide its head in order to remain unseen. Another section of the bourgeoisie desired, because Bonaparte was already in the presidential chair, to leave him sitting in it, so that everything could remain in the same old rut. They were indignant because their parliament did not openly infringe the constitution and abdicate without ceremony. 
The Department Councils, those provincial representative bodies of the big bourgeoisie, which met from August 25 on during the recess of the National Assembly, declared almost unanimously for revision, and thus against parliament and in favor of Bonaparte.

Still more unequivocally than in its falling out with its parliamentary representatives, the bourgeoisie displayed its wrath against its literary representatives, its own press. The sentences to ruinous fines and shameless terms of imprisonment, on the verdicts of bourgeois juries, for every attack of bourgeois journalists on Bonaparte's usurpationist desires, for every attempt of the press to defend the political rights of the bourgeoisie against the executive power, astonished not merely France, but all Europe.

While the parliamentary party of Order, by its clamor for tranquillity, as I have shown, committed itself to quiescence, while it declared the political rule of the bourgeoisie to be incompatible with the safety and existence of the bourgeoisie - by destroying with its own hands, in the struggle against the other classes of society, all the conditions for its own regime, the parliamentary regime - the extraparliamentary mass of the bourgeoisie, on the other hand, by its servility toward the President, by its vilification of parliament, by its brutal maltreatment of its own press, invited Bonaparte to suppress and annihilate its speaking and writing section, its politicians and its literati, its platform and its press, so it would then be able to pursue its private affairs with full confidence in the protection of a strong and unrestricted government. It declared unequivocally that it longed to get rid of its own political rule in order to get rid of the troubles and dangers of ruling.

And this extraparliamentary bourgeoisie, which had already rebelled against the purely parliamentary and literary struggle for the rule of its own class, and had betrayed the leaders of this struggle, now dares after the event to indict the proletariat for not having risen in a bloody struggle, a life-and-death struggle on its behalf! This bourgeoisie, which every moment sacrificed its general class interests, that is, its political interests, to the narrowest and most sordid private interests, and demanded a similar sacrifice from its representatives, now moans that the proletariat has sacrificed its ideal political interests to its material interests. It poses as a lovely creature that has been misunderstood and deserted in the decisive hour by the proletariat, misled by socialists. And it finds a general echo in the bourgeois world. Naturally, I do not speak here of German shyster politicians and riff-raff of the same persuasion. I refer, for example, to the already quoted Economist, which as late as November 29, 1851, that is, four days prior to the coup d'etat, declared Bonaparte to be the "guardian of order" but Thiers and Berryer to be "anarchists," and on December 27, 1851, after Bonaparte had quieted these "anarchists," is already vociferous about the treason to "the skill, knowledge, discipline, spiritual insight, intellectual resources, and moral weight of the middle and upper ranks" committed by the masses of "ignorant, untrained, and stupid proletaires." The stupid, ignorant, and vulgar mass was none other than the bourgeois mass itself.

In the year 1851, France, to be sure, had passed through a kind of minor trade crisis. The end of February showed a decline in exports compared with 1850; in March trade suffered and factories closed down; in April the position of the industrial departments appeared as desperate as after the February days; in May business had still not revived; as late as June 28 the holdings of the Bank of France showed, by the enormous growth of deposits and the equally great decrease in advances on bills of exchange, that production was at a standstill, and it was not until the middle of October that a progressive improvement of business again set in. The French bourgeoisie attributed this trade stagnation to purely political causes, to the struggle between parliament and the executive power, to the precariousness of a merely provisional form of state, to the terrifying prospect of the second Sunday in May of 1852. I will not deny that all these circumstances had a depressing effect on some branches of industry in Paris and the departments. But in any case the influence of political conditions was only local and inconsiderable. Does this require further proof than the fact that the improvement of trade set in toward the middle of October, at the very moment when 
the political situation grew worse, the political horizon darkened, and a thunderbolt from Elysium was expected at any moment? For the rest, the French bourgeois, whose "skill, knowledge, spiritual insight, and intellectual resources" reach no further than his nose, could throughout the period of the Industrial Exhibition in London ${ }^{4}$ have found the cause of his commercial misery right under his nose. While in France factories were closed down, in England commercial bankruptcies broke out. While in April and May the industrial panic reached a climax in France, in April and May the commercial panic reached a climax in England. Like the French woolen industry, the English woolen industry suffered, and as French silk manufacture, so did English silk manufacture. True, the English cotton mills continued working, but no longer at the same profits as in 1849 and 1850. The only difference was that the crisis in France was industrial, in England commercial; that while in France the factories stood idle, in England they extended operations, but under less favorable conditions than in preceding years; that in France it was exports, in England imports which were hardest hit. The common cause, which is naturally not to be sought within the bounds of the French political horizon, was obvious. The years 1849 and 1850 were years of the greatest material prosperity and of an overproduction that appeared as such only in 1851. At the beginning of this year it was given a further special impetus by the prospect of the Industrial Exhibition. In addition there were the following special circumstances: first, the partial failure of the cotton crop in 1850 and 1851, then the certainty of a bigger cotton crop than had been expected; first the rise, then the sudden fall - in short, the fluctuations in the price of cotton. The crop of raw silk, in France at least, had turned out to be even below the average yield. Woolen manufacture, finally, had expanded so much since 1848 that the production of wool could not keep pace with it and the price of raw wool rose out of all proportion to the price of woolen manufactures. Here, then, in the raw material of three industries for the world market, we already have three-fold material for a stagnation in trade. Apart from these special circumstances, the apparent crisis of 1851 was nothing else but the halt which overproduction and overspeculation invariably make in completing the industrial cycle, before they summon all their strength in order to rush feverishly through the final phase of this cycle and arrive once more at their starting point, the general trade crisis. During such intervals in the history of trade, commercial bankruptcies break out in England, while in France industry itself is reduced to idleness, partly forced into retreat by the competition, just then becoming intolerable, of the English in all markets, and partly singled out for attack as a luxury industry by every business stagnation. Thus besides the general crisis France goes through national trade crises of her own, which are nevertheless determined and conditioned far more by the general state of the world market than by French local influences. It will not be without interest to contrast the judgment of the English bourgeois with the prejudice of the French bourgeois. In its annual trade report for 1851, one of the largest Liverpool houses writes:

"Few years have more thoroughly belied the anticipations formed at their commencement than the one just closed; instead of the great prosperity which was almost unanimously looked for it has proved one of the most discouraging that has been seen for the last quarter of a century - this, of course, refers to the mercantile, not to the manufacturing classes. And yet there certainly were grounds for anticipating the reverse at the beginning of the year - stocks of produce were moderate, money was abundant, and food was cheap, a plentiful harvest well secured, unbroken peace on the Continent, and no political or fiscal disturbances at home; indeed, the wings of commerce were never more unfettered.... To what source, then, is this disastrous result to be attributed? We believe to overtrading in both imports and exports. Unless our merchants will put more stringent limits to their freedom of action, nothing but a triennial panic can keep us in check."

Now picture to yourself the French bourgeois, how in the throes of this business panic his tradecrazy brain is tortured, set in a whirl, and stunned by rumors of coups d'etat and the restoration of 
universal suffrage, by the struggle between parliament and the executive power, by the Fronde war between Orleanists and Legitimists, by the communist conspiracies in the south of France, by alleged Jacqueries in the departments of Nievre and Cher, by the advertisements of the different candidates for the presidency, by the cheapjack solutions offered by the journals, by the threats of the republicans to uphold the constitution and universal suffrage by force of arms, by the gospelpreaching emigre heroes in partibus, who announced that the world would come to an end on the second Sunday in May, 1852 - think of all this and you will comprehend why in this unspeakable, deafening chaos of fusion, revision, prorogation, constitution, conspiration, coalition, emigration, usurpation, and revolution, the bourgeois madly snorts at his parliamentary republic:

"Rather an end with terror than terror without end!"

Bonaparte understood this cry. His power of comprehension was sharpened by the growing turbulence of creditors, who with each sunset which brought settling day, the second Sunday in May, 1852, nearer, saw a movement of the stars protesting their earthly bills of exchange. They had become veritable astrologers. The National Assembly had blighted Bonaparte's hopes of a constitutional prolongation of his authority; the candidature of the Prince of Joinville forbade further vacillation.

If ever an event has, well in advance of its coming, cast its shadow before, it was Bonaparte's coup d'etat. As early as January 29, 1849, barely a month after his election, he had made a proposal about it to Changarnier. In the summer of 1849 his own Prime Minister, Odilon Barrot, had covertly denounced the policy of coups d'etat; in the winter of 1850 Thiers had openly done so. In May, 1851, Persigny had sought once more to win Changarnier for the coup; the Messager de l'Assemblee had published an account of these negotiations. During every parliamentary storm the Bonapartist journals threatened a coup d'etat, and the nearer the crisis drew, the louder their tone became. In the orgies that Bonaparte kept up every night with men and women of the "swell mob," as soon as the hour of midnight approached and copious potations had loosened tongues and fired imaginations, the coup d'etat was fixed for the following morning. Swords were drawn, glasses clinked, the representatives were thrown out the window, the imperial mantle fell upon Bonaparte's shoulders, until the following morning banished the ghost once more and astonished Paris learned, from vestals of little reticence and from indiscreet paladins, of the danger it had once again escaped. During the months of September and October rumors of a coup d'etat followed fast, one after the other. Simultaneously the shadow took on color, like a variegated daguerreotype. Look up the September and October copies of the organs of the European daily press and you will find, word for word, intimations like the following: "Paris is full of rumors of a coup d'etat. The capital is to be filled with troops during the night, and the next morning is to bring decrees which will dissolve the National Assembly, declare the Department of the Seine in a state of siege, restore universal suffrage, and appeal to the people. Bonaparte is said to be seeking ministers for the execution of these illegal decrees." The dispatches that bring these tidings always end with the fateful word "postponed." The coup d'etat was ever the fixed idea of Bonaparte. With this idea he had again set foot on French soil. He was so obsessed by it that he continually betrayed it and blurted it out. He was so weak that, just as continually, he gave it up again. The shadow of the coup d'etat had become so familiar to the Parisians as a specter that they were not willing to believe in it when it finally appeared in the flesh. What allowed the coup d'etat to succeed was therefore neither the reticent reserve of the chief of the Society of December 10 nor the fact that the National Assembly was caught unawares. If it succeeded, it succeeded despite its indiscretion and with its foreknowledge, a necessary, inevitable result of antecedent developments.

On October 10 Bonaparte announced to his ministers his decision to restore universal suffrage; on the sixteenth they handed in their resignations; on the twenty-sixth Paris learned of the formation of the Thorigny Ministry. Police Prefect Carlier was simultaneously replaced by Maupas; the 
head of the First Military Division, Magnan, concentrated the most reliable regiments in the capital. On November 4 the National Assembly resumed its sessions. It had nothing better to do than to recapitulate in a short, succinct form the course it had gone through and to prove that it was buried only after it had died.

The first post it forfeited in the struggle with the executive power was the ministry. It had solemnly to admit this loss by accepting at full value the Thorigny Ministry, a mere shadow cabinet. The Permanent Commission had received M. Giraud with laughter when he presented himself in the name of the new ministers. Such a weak ministry for such strong measures as the restoration of universal suffrage! Yet the precise object was to get nothing through in parliament, but everything against parliament.

On the very first day of its reopening, the National Assembly received the message from Bonaparte in which he demanded the restoration of universal suffrage and the abolition of the law of May 31, 1850. The same day his ministers introduced a decree to this effect. The National Assembly at once rejected the ministry's motion of urgency and rejected the law itself on November 13 by three hundred and fifty-five votes to three hundred and forty-eight. Thus, it tore up its mandate once more; it once more confirmed the fact that it had transformed itself from the freely elected representatives of the people into the usurpatory parliament of a class; it acknowledged once more that it had itself cut in two the muscles which connected the parliamentary head with the body of the nation.

If by its motion to restore universal suffrage the executive power appealed from the National Assembly to the people, the legislative power appealed by its Quaestors' Bill from the people to the army. This Quaestors' Bill was to establish its right of directly requisitioning troops, of forming a parliamentary army. While it thus designated the army as the arbitrator between itself and the people, between itself and Bonaparte, while it recognized the army as the decisive state power, it had to confirm, on the other hand, the fact that it had long given up its claim to dominate this power. By debating its right to requisition troops, instead of requisitioning them at once, it betrayed its doubts about its own powers. By rejecting the Quaestors' Bill, it made public confession of its impotence. This bill was defeated, its proponents lacking a hundred and eight votes of a majority. The Montagne thus decided the issue. It found itself in the position of Buridan's ass - not, indeed, between two bundles of hay with the problem of deciding which was the more attractive, but between two showers of blows with the problem of deciding which was the harder. On the one hand, there was the fear of Changarnier; on the other, the fear of Bonaparte. It must be confessed that the position was not a heroic one.

On November 18 an amendment was moved to the law on municipal elections introduced by the party of Order, to the effect that instead of three years', one year's domicile should suffice for municipal electors. The amendment was lost by a single vote, but this one vote immediately proved to be a mistake. By splitting up into its hostile factions, the party of Order had long ago forfeited its independent parliamentary majority. It showed now that there was no longer any majority at all in parliament. The National Assembly had become incapable of transacting business. Its atomic constituents were no longer held together by any force of cohesion; it had drawn its last breath; it was dead.

Finally, a few days before the catastrophe, the extra-parliamentary mass of the bourgeoisie was solemnly to confirm once more its breach with the bourgeoisie in parliament. Thiers, as a parliamentary hero infected more than the rest with the incurable disease of parliamentary cretinism, had, after the death of parliament, hatched out, together with the Council of State, a new parliamentary intrigue, a Responsibility Law by which the President was to be firmly held within the limits of the constitution. Just as, on laying the foundation stone of the new market halls in Paris on September 15, Bonaparte, like a second Masaniello, had enchanted the dames des balles, the fishwives - to be sure, one fishwife outweighed seventeen burgraves in real power - just as after the introduction of the Quaestors' Bill he enraptured the lieutenants whom he 
regaled in the Elysee, so now, on November 25, he swept off their feet the industrial bourgeoisie, which had gathered at the circus to receive at his hands prize medals for the London Industrial Exhibition.

I shall give the significant portion of his speech as reported in the Journal des Débats:

" With such unhoped-for successes, I am justified in reiterating how great the French Republic would be if it were permitted to pursue its real interests and reform its institutions, instead of being constantly disturbed by demagogues, on the one hand, and by monarchist hallucinations, on the other.' (Loud, stormy and repeated applause from every part of the amphitheater.) 'The monarchist hallucinations hinder all progress and all important branches of industry. In place of progress nothing but struggle. One sees men who were formerly the most zealous supporters of the royal authority and prerogative become partisans of a Convention merely in order to weaken the authority that has sprung from universal suffrage.' (Loud and repeated applause.) 'We see men who have suffered most from the Revolution, and have deplored it most, provoke a new one, and merely in order to fetter the nation's will.... I promise you tranquillity for the future,' etc., etc. (Bravo, bravo, a storm of bravos.)"

Thus the industrial bourgeoisie applauds with servile bravos the coup d'etat of December 2, the annihilation of parliament, the downfall of its own rule, the dictatorship of Bonaparte. The thunder of applause on November 25 had its answer in the thunder of cannon on December $4,{ }^{5}$ and it was on the house of Monsieur Sallandrouze, who had clapped most, that they clapped most of the bombs.

Cromwell, when he dissolved the Long Parliament, went alone into its midst, took out his watch so that it should not continue to exist a minute after the time limit he had fixed, and drove out each one of the members of Parliament with hilariously humorous taunts. Napoleon, smaller than his prototype, at least betook himself on the eighteenth Brumaire to the legislative body and read out to it, though in a faltering voice, its sentence of death. The second Bonaparte, who, moreover, found himself in possession of an executive power very different from that of Cromwell or Napoleon, sought his model not in the annals of world history but in the annals of the Society of December 10, in the annals of the criminal courts. He robs the Bank of France of twenty-five million francs, buys General Magnan with a million, the soldiers with fifteen francs apiece and liquor, comes together with his accomplices secretly like a thief in the night, has the houses of the most dangerous parliamentary leaders broken into, and Cavaignac, Lamoricière, Le Flô, Changarnier, Charras, Thiers, Baze, etc., dragged from their beds and put in prison, the chief squares of Paris and the parliamentary building occupied by troops, and cheapjack placards posted early in the morning on all the walls, proclaiming the dissolution of the National Assembly and the Council of State, the restoration of universal suffrage, and the placing of the Seine Department in a state of siege. In like manner he inserted a little later in the Moniteur a false document which asserted that influential parliamentarians had grouped themselves around him and formed a state consulta.

The rump parliament, assembled in the mairie building of the Tenth Arrondissement and consisting mainly of Legitimists and Orleanists, votes the deposition of Bonaparte amid repeated cries of "Long live the Republic," unfailingly harangues the gaping crowds before the building, and is finally led off in the custody of African sharpshooters, first to the d'Orsay barracks, and later packed into prison vans and transported to the prisons of Mazas, Ham, and Vincennes. Thus ended the party of Order, the Legislative Assembly, and the February Revolution.

Before hastening to close, let us briefly summarize the latter's history:

1. First period. From February 24 to May 4, 1848. February period. Prologue. Universalbrotherhood swindle. 
2. Second period. Period of constituting the republic and of the Constituent National Assembly.

a. May 4 to June 25, 1848. Struggle of all classes against the proletariat. Defeat of the proletariat in the June days.

b. June 25 to December 10, 1848. Dictatorship of the pure bourgeois republicans. Drafting of the constitution. Proclamation of a state of siege in Paris. The bourgeois dictatorship set aside on December 10 by the election of Bonaparte as President.

c. December 20, 1848, to May 28, 1849. Struggle of the Constituent Assembly with Bonaparte and with the party of Order in alliance with him. Passing of the Constituent Assembly. Fall of the republican bourgeoisie.

3. Third period. Period of the constitutional republic and of the Legislative National Assembly.

a. May 28, 1849, to June 13, 1849. Struggle of the petty bourgeoisie with the bourgeoisie and with Bonaparte. Defeat of the petty-bourgeois democracy.

b. June 13, 1849, to May 31, 1850. Parliamentary dictatorship of the party of Order. It completes its rule by abolishing universal suffrage, but loses the parliamentary ministry.

c. May 31, 1850, to December 2, 1851. Struggle between the parliamentary bourgeoisie and Bonaparte.

(1) May 31, 1850, to January 12, 1851. The Assembly loses the supreme command of the army.

(2) January 12 to April 11, 1851. It is worsted in its attempts to regain the administrative power.

The party of Order loses its independent parliamentary majority. It forms a coalition with the republicans and the Montagne.

(3) April 11, 1851, to October 9, 1851. Attempts at revision, fusion, prorogation. The party of Order decomposes into its separate constituents. The breach between the bourgeois parliament and press and the mass of the bourgeoisie becomes definite.

(4) October 9 to December 2, 1851. Open breach between parliament and the executive power. The Assembly performs its dying act and succumbs, left in the lurch by its own class, by the army, and by all the remaining classes. Passing of the parliamentary regime and of bourgeois rule. Victory of Bonaparte. Parody of restoration of empire.

\footnotetext{
${ }^{1}$ In the 1850s, the Count of Chambord, the Legitimist pretender to the French throne, lived in Venice.

2 The reference is to tactical disagreements in the Legitimist camp during the Restoration period. Louis XVIII and Villele favoured a more cautious introduction of reactionary measures while the Count d'Artois (King Charles X from 1824) and Polignac ignored the actual situation in France and advocated the complete restoration of the pre-revolutionary regime.

The Tuileries Palace in Paris was Louis XVIII's residence.

The Pavillon Marsan, one of the wings of the Palace, was the residence of the Count d'Artois during the Restoration.

${ }^{3}$ General Magnan directed the suppression of the armed uprising of workers and artisans in Lyons on June 15,1849

${ }^{4}$ The Great Exhibition in London, from May to October 1851, was the first world trade and industrial exhibition.

5 On December 4, 1851 government troops commanded by Bonapartist generals suppressed a republican uprising directed against the coup d'état in Paris. The uprising was led by a group of Left-
} 
wing deputies of the Legislative Assembly and leaders of workers' corporations and secret societies. Employing cannon, the government troops destroyed the barricades erected by the defenders of the Republic. While fighting the insurgents, drunken soldiers and officers fired at passers-by, at customers in cafés and at spectators at windows and balconies. Several bourgeois mansions were also damaged in this Bonapartist terror. 


\section{VII}

The social republic appeared as a phrase, as a prophecy, on the threshold of the February Revolution. In the June days of 1848, it was drowned in the blood of the Paris proletariat, but it haunts the subsequent acts of the drama like a ghost. The democratic republic announces its appearance. It is dissipated on June 13,1849, together with its deserting petty bourgeois, but in its flight it redoubles its boastfulness. The parliamentary republic together with the bourgeoisie takes possession of the entire state; it enjoys its existence to the full, but December 2, 1851, buries it to the accompaniment of the anguished cry of the coalesced royalists: "Long live the Republic!"

The French bourgeoisie balked at the domination of the working proletariat; it has brought the lumpen proletariat ${ }^{1}$ to domination, with the Chief of the Society of December 10 at the head. The bourgeoisie kept France in breathless fear of the future terrors of red anarchy - Bonaparte discounted this future for it when, on December 4, he had the eminent bourgeois of the Boulevard Montmartre and the Boulevard des Italiens shot down at their windows by the drunken army of law and order. The bourgeoisie apotheosized the sword; the sword rules it. It destroyed the revolutionary press; its own press is destroyed. It placed popular meetings under police surveillance; its salons are placed under police supervision. It disbanded the democratic National Guard, its own National Guard is disbanded. It imposed a state of siege; a state of siege is imposed upon it. It supplanted the juries by military commissions; its juries are supplanted by military commissions. It subjected public education to the sway of the priests; the priests subject it to their own education. It jailed people without trial, it is being jailed without trial. It suppressed every stirring in society by means of state power; every stirring in its society is suppressed by means of state power. Out of enthusiasm for its moneybags it rebelled against its own politicians and literary men; its politicians and literary men are swept aside, but its moneybag is being plundered now that its mouth has been gagged and its pen broken. The bourgeoisie never tired of crying out to the revolution what St. Arsenius cried out to the Christians: "Fuge, tace, quiesce!" ["Flee, be silent, keep still!"] Bonaparte cries to the bourgeoisie: "Fuge, tace, quiesce!"

The French bourgeoisie had long ago found the solution to Napoleon's dilemma: "In fifty years Europe will be republican or Cossack." It solved it in the "Cossack republic." No Circe using black magic has distorted that work of art, the bourgeois republic, into a monstrous shape. That republic has lost nothing but the semblance of respectability. Present-day France was already contained in the parliamentary republic. It required only a bayonet thrust for the bubble to burst and the monster to leap forth before our eyes.

Why did the Paris proletariat not rise in revolt after December 2?

The overthrow of the bourgeoisie had as yet been only decreed; the decree was not carried out. Any serious insurrection of the proletariat would at once have put new life into the bourgeoisie, reconciled it with the army, and insured a second June defeat for the workers.

On December 4 the proletariat was incited by bourgeois and shopkeeper to fight. On the evening of that day several legions of the National Guard promised to appear, armed and uniformed, on the scene of battle. For the bourgeois and the shopkeeper had learned that in one of his decrees of December 2 Bonaparte had abolished the secret ballot and had ordered them to put a "yes" or "no" after their names on the official registers. The resistance of December 4 intimidated Bonaparte. During the night he had placards posted on all the street corners of Paris announcing the restoration of the secret ballot. The bourgeois and the shopkeeper believed they had gained their objective. Those who failed to appear next morning were the bourgeois and the shopkeeper.

By a coup de main the night of December 1-2 Bonaparte had robbed the Paris proletariat of its leaders, the barricade commanders. An army without officers, averse to fighting under the banner of the Montagnards because of the memories of June, 1848 and 1849, and May, 1850, it left to its 
vanguard, the secret societies, the task of saving the insurrectionary honor of Paris, which the bourgeoisie had surrendered to the military so unresistingly that, subsequently, Bonaparte could disarm the National Guard with the sneering motive of his fear that its weapons would be turned against it by the anarchists!

"This is the complete and final triumph of socialism!" Thus Guizot characterized December 2. But if the overthrow of the parliamentary republic contains within itself the germ of the triumph of the proletarian revolution, its immediate and obvious result was Bonaparte's victory over parliament, of the executive power over the legislative power, of force without phrases over the force of phrases. In parliament the nation made its general will the law; that is, it made the law of the ruling class its general will. It renounces all will of its own before the executive power and submits itself to the superior command of an alien, of authority. The executive power, in contrast to the legislative one, expresses the heteronomy of a nation in contrast to its autonomy. France therefore seems to have escaped the despotism of a class only to fall back under the despotism of an individual, and what is more, under the authority of an individual without authority. The struggle seems to be settled in such a way that all classes, equally powerless and equally mute, fall on their knees before the rifle butt.

But the revolution is thoroughgoing. It is still traveling through purgatory. It does its work methodically. By December 2, 1851, it had completed half of its preparatory work; now it is completing the other half. It first completed the parliamentary power in order to be able to overthrow it. Now that it has achieved this, it completes the executive power, reduces it to its purest expression, isolates it, sets it up against itself as the sole target, in order to concentrate all its forces of destruction against it. And when it has accomplished this second half of its preliminary work, Europe will leap from its seat and exult: Well burrowed, old mole! ${ }^{2}$

The executive power with its enormous bureaucratic and military organization, with its wideranging and ingenious state machinery, with a host of officials numbering half a million, besides an army of another half million - this terrifying parasitic body which enmeshes the body of French society and chokes all its pores sprang up in the time of the absolute monarchy, with the decay of the feudal system which it had helped to hasten. The seignorial privileges of the landowners and towns became transformed into so many attributes of the state power, the feudal dignitaries into paid officials, and the motley patterns of conflicting medieval plenary powers into the regulated plan of a state authority whose work is divided and centralized as in a factory.

The first French Revolution, with its task of breaking all separate local, territorial, urban, and provincial powers in order to create the civil unity of the nation, was bound to develop what the monarchy had begun, centralization, but at the same time the limits, the attributes, and the agents of the governmental power. Napoleon completed this state machinery. The Legitimate Monarchy and the July Monarchy added nothing to it but a greater division of labor, increasing at the same rate as the division of labor inside the bourgeois society created new groups of interests, and therefore new material for the state administration. Every common interest was immediately severed from the society, countered by a higher, general interest, snatched from the activities of society's members themselves and made an object of government activity - from a bridge, a schoolhouse, and the communal property of a village community, to the railroads, the national wealth, and the national University of France. Finally the parliamentary republic, in its struggle against the revolution, found itself compelled to strengthen the means and the centralization of governmental power with repressive measures. All revolutions perfected this machine instead of breaking it. The parties, which alternately contended for domination, regarded the possession of this huge state structure as the chief spoils of the victor.

But under the absolute monarchy, during the first Revolution, and under Napoleon the bureaucracy was only the means of preparing the class rule of the bourgeoisie. Under the Restoration, under Louis Philippe, under the parliamentary republic, it was the instrument of the ruling class, however much it strove for power of its own. 
Only under the second Bonaparte does the state seem to have made itself completely independent. The state machinery has so strengthened itself vis-à-vis civil society that the Chief of the Society of December 10 suffices for its head - an adventurer dropped in from abroad, raised on the shoulders of a drunken soldiery which he bought with whisky and sausages and to which he has to keep throwing more sausages. Hence the low-spirited despair, the feeling of monstrous humiliation and degradation that oppresses the breast of France and makes her gasp. She feels dishonored.

And yet the state power is not suspended in the air. Bonaparte represented a class, and the most numerous class of French society at that, the small-holding peasants.

Just as the Bourbons were the dynasty of the big landed property and the Orleans the dynasty of money, so the Bonapartes are the dynasty of the peasants, that is, the French masses. The chosen of the peasantry is not the Bonaparte who submitted to the bourgeois parliament but the Bonaparte who dismissed the bourgeois parliament. For three years the towns had succeeded in falsifying the meaning of the December 10 election and in cheating the peasants out of the restoration of the Empire. The election of December 10, 1848, has been consummated only by the coup d'état of December 2, 1851.

The small-holding peasants form an enormous mass whose members live in similar conditions but without entering into manifold relations with each other. Their mode of production isolates them from one another instead of bringing them into mutual intercourse. The isolation is furthered by France's poor means of communication and the poverty of the peasants. Their field of production, the small holding, permits no division of labor in its cultivation, no application of science, and therefore no multifariousness of development, no diversity of talent, no wealth of social relationships. Each individual peasant family is almost self-sufficient, directly produces most of its consumer needs, and thus acquires its means of life more through an exchange with nature than in intercourse with society. A small holding, the peasant and his family; beside it another small holding, another peasant and another family. A few score of these constitute a village, and a few score villages constitute a department. Thus the great mass of the French nation is formed by the simple addition of homologous magnitudes, much as potatoes in a sack form a sack of potatoes. Insofar as millions of families live under conditions of existence that separate their mode of life, their interests, and their culture from those of the other classes, and put them in hostile opposition to the latter, they form a class. Insofar as there is merely a local interconnection among these small-holding peasants, and the identity of their interests forms no community, no national bond, and no political organization among them, they do not constitute a class. They are therefore incapable of asserting their class interest in their own name, whether through a parliament or a convention. They cannot represent themselves, they must be represented. Their representative must at the same time appear as their master, as an authority over them, an unlimited governmental power which protects them from the other classes and sends them rain and sunshine from above. The political influence of the small-holding peasants, therefore, finds its final expression in the executive power which subordinates society to itself.

Historical tradition gave rise to the French peasants' belief in the miracle that a man named Napoleon would bring all glory back to them. And there turned up an individual who claims to be that man because he bears the name Napoleon, in consequence of the Code Napoleon, which decrees: "Inquiry into paternity is forbidden." After a twenty-year vagabondage and a series of grotesque adventures the legend is consummated, and the man becomes Emperor of the French. The fixed idea of the nephew was realized because it coincided with the fixed idea of the most numerous class of the French people.

But, it may be objected, what about the peasant uprisings in half of France, ${ }^{3}$ the raids of the army on the peasants, the mass incarceration and transportation of the peasants? 
Since Louis XIV, France has experienced no similar persecution of the peasants "on account of demagogic agitation." 4

But let us not misunderstand. The Bonaparte dynasty represents not the revolutionary, but the conservative peasant; not the peasant who strikes out beyond the condition of his social existence, the small holding, but rather one who wants to consolidate his holding; not the countryfolk who in alliance with the towns want to overthrow the old order through their own energies, but on the contrary those who, in solid seclusion within this old order, want to see themselves and their small holdings saved and favored by the ghost of the Empire. It represents not the enlightenment but the superstition of the peasant; not his judgment but his prejudice; not his future but his past; not his modern Cevennes but his modern Vendée. ${ }^{5}$ The three years' stern rule of the parliamentary republic freed a part of the French peasants from the Napoleonic illusion and revolutionized them, even though superficially; but the bourgeoisie violently repulsed them as often as they set themselves in motion. Under the parliamentary republic the modern and the traditional consciousness of the French peasant contended for mastery. The process took the form of an incessant struggle between the schoolmasters and the priests. The bourgeoisie struck down the schoolmasters. The peasants for the first time made efforts to behave independently vis-à-vis the government. This was shown in the continual conflict between the mayors and the prefects. The bourgeoisie deposed the mayors. Finally, during the period of the parliamentary republic, the peasants of different localities rose against their own offspring, the army. The bourgeoisie punished these peasants with sieges and executions. And this same bourgeoisie now cries out against the stupidity of the masses, the vile multitude that betrayed it to Bonaparte. The bourgeoisie itself has violently strengthened the imperialism of the peasant class; it has preserved the conditions that form the birthplaces of this species of peasant religion. The bourgeoisie, in truth, is bound to fear the stupidity of the masses so long as they remain conservative, and the insight of the masses as soon as they become revolutionary.

In the uprisings after the coup d'état, a part of the French peasants protested, arms in hand, against their own vote of December 10, 1848. The school they had gone to since 1848 had sharpened their wits. But they had inscribed themselves in the historical underworld; history held them to their word, and the majority was still so implicated that precisely in the reddest departments the peasant population voted openly for Bonaparte. In their view, the National Assembly had hindered his progress. He has now merely broken the fetters that the towns had imposed on the will of the countryside. In some parts the peasants even entertained the grotesque notion of a convention with Napoleon.

After the first Revolution had transformed the semi-feudal peasants into freeholders, Napoleon confirmed and regulated the conditions in which they could exploit undisturbed the soil of France which they had only just acquired, and could slake their youthful passion for property. But what is now ruining the French peasant is his small holding itself, the division of the land and the soil, the property form which Napoleon consolidated in France. It is exactly these material conditions which made the feudal peasant a small-holding peasant and Napoleon an emperor. Two generations sufficed to produce the unavoidable result: progressive deterioration of agriculture and progressive indebtedness of the agriculturist. The "Napoleonic" property form, which at the beginning of the nineteenth century was the condition of the emancipation and enrichment of the French countryfolk, has developed in the course of this century into the law of their enslavement and their pauperism. And just this law is the first of the "Napoleonic ideas" which the second Bonaparte has to uphold. If he still shares with the peasants the illusion that the cause of their ruin is to be sought not in the small holdings themselves but outside them - in the influence of secondary circumstances - his experiments will shatter like soap bubbles when they come in contact with the relations of production.

The economic development of small-holding property has radically changed the peasants' relations with the other social classes. Under Napoleon the fragmentation of the land in the 
countryside supplemented free competition and the beginning of big industry in the towns. The peasant class was the ubiquitous protest against the recently overthrown landed aristocracy. The roots that small-holding property struck in French soil deprived feudalism of all nourishment. The landmarks of this property formed the natural fortification of the bourgeoisie against any surprise attack by its old overlords. But in the course of the nineteenth century the urban usurer replaced the feudal one, the mortgage replaced the feudal obligation, bourgeois capital replaced aristocratic landed property. The peasant's small holding is now only the pretext that allows the capitalist to draw profits, interest, and rent from the soil, while leaving it to the agriculturist himself to see to it how he can extract his wages. The mortgage debt burdening the soil of France imposes on the French peasantry an amount of interest equal to the annual interest on the entire British national debt. Small-holding property, in this enslavement by capital toward which its development pushes it unavoidably, has transformed the mass of the French nation into troglodytes. Sixteen million peasants (including women and children) dwell in caves, a large number of which have but one opening, others only two and the most favored only three. Windows are to a house what the five senses are to the head. The bourgeois order, which at the beginning of the century set the state to stand guard over the newly emerged small holdings and fertilized them with laurels, has become a vampire that sucks the blood from their hearts and brains and casts them into the alchemist's caldron of capital. The Code Napoléon is now nothing but the codex of distraints, of forced sales and compulsory auctions. To the four million (including children, etc.) officially recognized paupers, vagabonds, criminals, and prostitutes in France must be added another five million who hover on the margin of existence and either have their haunts in the countryside itself or, with their rags and their children, continually desert the countryside for the towns and the towns for the countryside. Therefore the interests of the peasants are no longer, as under Napoleon, in accord with, but are now in opposition to bourgeois interests, to capital. Hence they find their natural ally and leader in the urban proletariat, whose task it is to overthrow the bourgeois order. But "strong and unlimited government" - and this is the second "Napoleonic idea" that the second Napoleon has to carry out - is called upon to defend this "material order" by force. This "material order" also serves, in all Bonaparte's proclamations, as the slogan against the rebellious peasants.

In addition to the mortgage which capital imposes on it, the small holding is burdened by taxes. Taxes are the life source of the bureaucracy, the army, the priests, and the court - in short, of the entire apparatus of the executive power. Strong government and heavy taxes are identical. By its very nature, small-holding property forms a basis for an all-powerful and numberless bureaucracy. It creates a uniform level of personal and economic relationships over the whole extent of the country. Hence it also permits uniform action from a supreme center on all points of this uniform mass. It destroys the aristocratic intermediate steps between the mass of the people and the power of the state. On all sides, therefore, it calls forth the direct intrusion of this state power and the interposition of its immediate organs. Finally, it produces an unemployed surplus population which can find no place either on the land or in the towns and which perforce reaches out for state offices as a sort of respectable alms, and provokes the creation of additional state positions. By the new markets which he opened with bayonets, and by the plundering of the Continent, Napoleon repaid the compulsory taxes with interest. These taxes were a spur to the industry of the peasant, whereas now they rob his industry of its last resources and complete his defenselessness against pauperism. An enormous bureaucracy, well gallooned and well fed, is the "Napoleonic idea" which is most congenial to the second Bonaparte. How could it be otherwise, considering that alongside the actual classes of society, he is forced to create an artificial caste for which the maintenance of his regime becomes a bread-and-butter question? Hence one of his first financial operations was the raising of officials' salaries to their old level and the creation of new sinecures.

Another "idée napoléonienne" [Napoleonic idea] is the domination of the priests as an instrument of government. But while at the time of their emergence the small-holding owners, in their accord 
with society, in their dependence on natural forces and submission to the authority which protected them from above, were naturally religious, now that they are ruined by debts, at odds with society and authority, and driven beyond their own limitations, they have become naturally irreligious.

Heaven was quite a pleasing addition to the narrow strip of land just won, especially as it makes the weather; it becomes an insult as soon as it is thrust forward as a substitute for the small holding. The priest then appears as only the anointed bloodhound of the earthly police - another "idée napoléonienne." The expedition against Rome will take place in France itself next time, but in a sense opposite from that of M. de Montalembert.

Finally, the culminating "idée napoléonienne" is the ascendancy of the army. The army was the "point d' honneur" of the small-holding peasants, it was they themselves transformed into heroes, defending their new possessions against the outer world, glorifying their recently won nationhood, plundering and revolutionizing the world. The uniform was their own state costume; war was their poetry; the small holding, enlarged and rounded off in imagination, was their fatherland, and patriotism the ideal form of the sense of property. But the enemies whom the French peasant now has to defend his property against are not the Cossacks; they are the huissiers [bailiffs] and the tax collectors. The small holding no longer lies in the so-called fatherland but in the registry of mortgages. The army itself is no longer the flower of the peasant youth; it is the swamp flower of the peasant lumpen proletariat. It consists largely of replacements, of substitutes, just as the second Bonaparte is himself only a replacement, the substitute for Napoleon. It now performs its deeds of valor by hounding the peasants in masses like chamois, by doing gendarme duty; and if the natural contradictions of his system chase the Chief of the Society of December 10 across the French border, his army, after some acts of brigandage, will reap, not laurels, but thrashings.

It is clear: All "idée napoléonienne" are ideas of the undeveloped small holding in the freshness of its youth; they are a contradiction to the outlived holdings. They are only the hallucinations of its death struggle, words transformed into phrases, spirits transformed into ghosts. But the parody of imperialism was necessary to free the mass of the French nation from the weight of tradition and to work out in pure form the opposition between state power and society. With the progressive deterioration of small-holding property, the state structure erected upon it collapses. The centralization of the state that modern society requires arises only on the ruins of the military-bureaucratic government machinery which was forged in opposition to feudalism.

The condition of the French peasants provides us with the answer to the riddle of the general elections of December 20 and 21, which bore the second Bonaparte up Mount Sinai, not to receive laws but to give them.

Obviously the bourgeoisie now had no choice but to elect Bonaparte. When the Puritans of the Council of Constance ${ }^{6}$ complained of the dissolute lives of the popes and wailed about the necessity for moral reform, Cardinal Pierre d'Ailly thundered at them: "Only the devil in person can still save the Catholic Church, and you ask for angels." Similarly, after the coup d'état the French bourgeoisie cried out: Only the Chief of the Society of December 10 can still save bourgeois society! Only theft can still save property; only perjury, religion; bastardy, the family; disorder, order!

As the executive authority which has made itself independent, Bonaparte feels it to be his task to safeguard "bourgeois order." But the strength of this bourgeois order lies in the middle class. He poses, therefore, as the representative of the middle class and issues decrees in this sense. Nevertheless, he is somebody solely because he has broken the power of that middle class, and keeps on breaking it daily. He poses, therefore, as the opponent of the political and literary power of the middle class. But by protecting its material power he revives its political power. Thus the cause must be kept alive, but the effect, where it manifests itself, must be done away with. But 
this cannot happen without small confusions of cause and effect, since in their interaction both lose their distinguishing marks. New decrees obliterate the border line. Bonaparte knows how to pose at the same time as the representative of the peasants and of the people in general, as a man who wants to make the lower classes happy within the framework of bourgeois society. New decrees cheat the "true socialists" 7 of their governmental skill in advance. But above all, Bonaparte knows how to pose as the Chief of the Society of December 10, as the representative of the lumpen proletariat to which he himself, his entourage, his government, and his army belong, and whose main object is to benefit itself and draw California lottery prizes from the state treasury. And he confirms himself as Chief of the Society of December 10 with decrees, without decrees, and despite decrees.

This contradictory task of the man explains the contradictions of his government, the confused groping which tries now to win, now to humiliate, first one class and then another, and uniformly arrays all of them against him; whose uncertainty in practice forms a highly comical contrast to the imperious, categorical style of the government decrees, a style slavishly copied from the uncle.

Industry and commerce, hence the business affairs of the middle class, are to prosper in hothouse fashion under the strong government: the grant of innumerable railroad concessions. But the Bonapartist lumpen proletariat is to enrich itself: those in the know play tripotage [underhand dealings] on the Exchange with the railroad concessions. But no capital is forthcoming for the railroads: obligation of the Bank to make advances on railroad shares. But at the same time the Bank is to be exploited for personal gain and therefore must be cajoled: release the Bank from the obligation to publish its report weekly; leonine ${ }^{8}$ agreement of the Bank with the government. The people are to be given employment: initiation of public works. But the public works increase the people's tax obligations: hence reduction of taxes by an attack on the rentiers, by conversion of the 5-percent bonds into 41/2-percent. But the middle class must again receive a sweetening: hence a doubling of the wine tax for the people, who buy wine retail, and a halving of the wine tax for the middle class, which drinks it wholesale; dissolution of the actual workers' associations, but promises of miraculous future associations. The peasants are to be helped: mortgage banks which hasten their indebtedness and accelerate the concentration of property. But these banks are to be used to make money out of the confiscated estates of the House of Orleans; no capitalist wants to agree to this condition, which is not in the decree, and the mortgage bank remains a mere decree, etc., etc.

Bonaparte would like to appear as the patriarchal benefactor of all classes. But he cannot give to one without taking from another. Just as it was said of the Duke de Guise in the time of the Fronde that he was the most obliging man in France because he gave all his estates to his followers, with feudal obligations to him, so Bonaparte would like to be the most obliging man in France and turn all the property and all the labor of France into a personal obligation to himself. He would like to steal all of France in order to make a present of it to France, or rather in order to buy France anew with French money, for as the Chief of the Society of December 10 he must buy what ought to belong to him. And to the Institution of Purchase belong all the state institutions, the Senate, the Council of State, the Assembly, the Legion of Honor, the military medals, the public laundries, the public works, the railroads, the general staff, the officers of the National Guard, the confiscated estates of the House of Orleans. The means of purchase is obtained by selling every place in the army and the government machinery. But the most important feature of this process, by which France is taken in order to give to her, are the percentages that find their way into the pockets of the head and the members of the Society of December 10 during the turnover. The witticism with which Countess L., the mistress of M. de Morny, characterized the confiscation of the Orleans estates - "It is the first vol [the word means both "flight" and "theft"] of the eagle" - is applicable to every flight of this eagle, who is more like a raven. ${ }^{9} \mathrm{He}$ and his followers call out to one another like that Italian Carthusian admonishing the miser who 
ostentatiously counted the goods on which he could still live for years: "Tu fai conto sopra $i$ beni, bisogna prima far il conto sopra gli anni" [Thou countest thy goods, thou shouldst first count thy years]. In order not to make a mistake in the years, they count the minutes. At the court, in the ministries, at the head of the administration and the army, a gang of blokes of whom the best that can be said is that one does not know whence they come - these noisy, disreputable, rapacious bohemians who crawl into gallooned coats with the same grotesque dignity as the high dignitaries of Soulouque - elbow their way forward. One can visualize clearly this upper stratum of the Society of December 10 if one reflects that Veron-Crevel [A dissolute philistine character in Balzac's novel Cousin Bette] is its preacher of morals and Granier de Cassagnac its thinker. When Guizot, at the time of his ministry, turned this Granier of an obscure newspaper into a dynastic opponent, he used to boast of him with the quip: "C'est le roi des droles" [He is the king of buffoons]. It would be wrong to recall either the Regency ${ }^{10}$ or Louis XV in connection with Louis Bonaparte's court and clique. For "often before France has experienced a government of mistresses, but never before a government of kept men." Driven by the contradictory demands of his situation, and being at the same time, like a juggler, under the necessity of keeping the public gaze on himself, as Napoleon's successor, by springing constant surprises - that is to say, under the necessity of arranging a coup d'état in miniature every day - Bonaparte throws the whole bourgeois economy into confusion, violates everything that seemed inviolable to the Revolution of 1848, makes some tolerant of revolution and makes others lust for it, and produces anarchy in the name of order, while at the same time stripping the entire state machinery of its halo, profaning it and making it at once loathsome and ridiculous. The cult of the Holy Tunic of Trier ${ }^{11}$ he duplicates in Paris in the cult of the Napoleonic imperial mantle. But when the imperial mantle finally falls on the shoulders of Louis Bonaparte, the bronze statue of Napoleon will come crashing down from the top of the Vendôme Column. ${ }^{12}$

\footnotetext{
${ }^{1}$ Roughly translated as slum workers or the mob, this term identifies the class of outcast, degenerated and submerged elements that make up a section of the population of industrial centers. It includes beggars, prostitutes, gangsters, racketeers, swindlers, petty criminals, tramps, chronic unemployed or unemployables, persons who have been cast out by industry, and all sorts of declassed, degraded or degenerated elements. In times of prolonged crisis (depression), innumerable young people also, who cannot find an opportunity to enter into the social organism as producers, are pushed into this limbo of the outcast. Here demagogues and fascists of various stripes find some area of the mass base in time of struggle and social breakdown, when the ranks of the Lumpenproletariat are enormously swelled by ruined and declassed elements from all layers of a society in decay.

The term was coined by Marx in The German Ideology in the course of a critique of Max Stirner. In passage of The Ego and His Own which Marx is criticising at the time, Stirner frequently uses the term Lumpe and applies it as a prefix, but never actually used the term "lumpenproletariat." Lumpen originally meant "rags," but began to be used to mean "a person in rags." From having the sense of "ragamuffin," it came to mean "riff-raff" or "knave," and by the beginning of the eighteenth century it began to be used freely as a prefix to make a range of perjorative terms. By the 1820s, "lumpen" could be tacked on to almost any German word.

The term was later used in the Communist Manifesto (where it is translated as "dangerous classes") and in Class Struggles in France, and elsewhere.

${ }^{2}$ Paraphrase from Shakespeare's Hamlet, Act 1, Scene 5: "Well said, old mole!"

${ }^{3}$ This refers to the participation of peasants in the republican uprisings in France in late 1851 in protest against the Bonapartist coup d'état. These uprisings, involving mainly artisans and workers of small towns and settlements, local peasants, tradesmen and intellectuals, embraced nearly twenty
} 
departments in south-east, south-west and central France. Lacking unity and centralisation they were fairly quickly suppressed by police and troops.

${ }^{4}$ Here Marx compares the Bonapartist authorities' reprisals against the participants in the republican movement, including peasants, with the persecution of the so-called demagogues in Germany in the 1820 s and 1830s. Demagogues in Germany were participants in the opposition movement of intellectuals. The name became current after the Karlsbad Conference of Ministers of the German States in August 1819, which adopted a special decision against the intrigues of "demagogues."

${ }^{5}$ Cévennes - a mountain region in the Languedoc Province of France where all uprising of peasants, known as the uprising of "Camisards" (camise in old French means shirt) took place between 1702 and 1705. The uprising, which began in protest against the persecution of Protestants, assumed all openly anti-feudal character.

Vendée - a department in Western France; during the French Revolution of 1789-94 a centre of a royalist revolt in which the mass of the local peasantry took part. The name "Vendée" came to denote counter-revolutionary activity.

${ }^{6}$ The Council of Constance (1414-18) was convened to strengthen the position of the Catholic Church at that period. The Council condemned the teachings of John Wycliffe and Jan Huss, and put an end to the split in the Catholic Church by electing a new Pope instead of the three pretenders competing for the papacy.

${ }^{7}$ The reference is to German or "true socialism" which was widespread in Germany in the 1840s, mostly among petty-bourgeois intellectuals. The "true socialists" - Karl Grün, Moses Hess, Hermann Kriege - substituted the sentimental preaching of love and brotherhood for the ideas of socialism and denied the need for a bourgeois-democratic revolution in Germany. Marx and Engels criticised this trend in the following works: The German Ideology, Circular Against Kriege, German Socialism in Verse and Prose and Manifesto of the Communist Party.

${ }^{8}$ From Aesop's fable about the lion who made a contract in which one partner got all the profits and the other all the disadvantages

${ }^{9}$ This witticism of Countess Lehon and the caustic remark of Madame de Girardin on the Bonapartist regime, which Marx quotes at the end of the paragraph, were forwarded to him, together with many other items used in The Eighteenth Brumaire, by Richard Reinhardt. a German refugee in Paris, Heinrich Heine's secretary, In his letter to Ferdinand Lassalle of February 23, 1852 Marx quotes a letter to him from Reinhardt, in the following passage: "As for de Morny, the minister who resigned with Dupin, he was known as the of his mistress' (Countess Lehon's) husband, which caused Emile de Girardin's wife to say that while it was not unprecedented for governments to be in the hands of men who were governed by their wives, none had ever been known to be in the hands of hommes entretenus [kept men]. Well, this same Countess Lehon holds a salon where she is one of Bonaparte's most vociferous opponents and it was she who, on the occasion of the confiscation of the Orleans' estates let fall 'C'est le premier vol de l'aigle'.A pun: "It is the first flight of the eagle" and "It is the first theft of the eagle."] Thanks to this remark of his wife's, Emile de Girardin was expelled." .

${ }^{10}$ The reference is to the Regency of Philippe of Orleans in France front 1715 to 1723 during the minority of Louis XV.

${ }^{11}$ The Holy Coat of Trier - a relic exhibited in the Catholic Cathedral at Trier, allegedly a garment of Christ of which he was stripped at his crucifixion. Generations of pilgrims came to venerate it.

12 The Vendôme Column was erected in Paris between 1806 and 1810 in tribute to the military victories of Napoleon I. It was made of bronze from captured enemy guns arid crowned by a statue of Napoleon; the statue was removed during the Restoration but re-erected in 1833. In the spring of 1871, by order of the Paris Commune, the Vendôme Column was destroyed as a symbol of militarism. 